\title{
Jacquemontia (Convolvulaceae) in Bolivia and Peru
}

\author{
John R. I. Wood ${ }^{1,2}$ (iD) \& Rosemary Clegg ${ }^{1,3}$
}

Summary. A taxonomic account of Jacquemontia Choisy in Bolivia and Peru is presented. All recognised species from the two countries are described and their distribution, ecology and conservation status are outlined. Separate keys to the species occurring in each country are also provided. All species are mapped and illustrated with line drawings and/or photographs. Five new species, Jacquemontia boliviana J.R.I.Wood, J. chuquisacensis J.R.I.Wood, J. cuspidata J.R.I.Wood, J. longipedunculata J.R.I.Wood and J. mairae J.R.I.Wood \& R.Clegg are described from the Andes of Bolivia. Taxonomic notes are provided for many species, J. heterantha Nees \& Mart. is treated as a synonym of J. cumanensis (Kunth) Kuntze and J. prominens Helwig of J. unilateralis (Roem. \& Schult.) O’Donell. Lectotypes are chosen for Convolvulus agrestis Mart. ex Choisy, C. mucronatus Benth., Ipomoea selloi var. rufescens (Meisn.) Hallier f., Jacquemontia acuminata Rusby, J. azurea var. alba Seeman, J. corymbulosa Benth., J. densiflora Rusby, J. guayaquilensis Meisn., J. pedunculata Rusby, J. sphaerocephala Meisn. and J. violacea var. densiflora Meisn.

Key Words. Andes, Argentina, Brazil, cerrado, chaco, conservation, distribution, Ecuador, new species, Paraguay, taxonomy.

\section{Introduction}

Jacquemontia Choisy is a medium-sized pantropical genus of around 120 species (Mabberley 2017) but the majority of species are neotropical, the greatest diversity being in Brazil. Most species are modest, twining or trailing species with pretty blue flowers. The genus is of little economic or ecological importance but a few species are cultivated as ornamentals including J. pentanthos (Jacq.) G.Don and J. tamnifolia (L.) Griseb., the former sometimes known as blue clustervine, the latter as hairy clustervine.

There is no monograph of Jacquemontia and the only major study (Robertson 1971) remains unpublished. The genus has the reputation of being somewhat complex at species level as species are reported to intergrade and be difficult to distinguish. There is little information in the literature about their biology or ecology, but it is presumed they are pollinated by bees or similar insects.

The current paper presents a taxonomic account of the genus in Peru and Bolivia and would serve for use in Ecuador, since all recognised Ecuadorian species are covered in the key. The paper aims to help the reader identify the different species and provides information about their distribution, habitat and, in some cases, their flowering patterns. Provisional information on their conservation status is provided, as the exact status of individual species is often uncertain.

\section{Materials and Methods}

This paper is based on a study of Jacquemontia in the field and the herbarium. The first author has collected and observed different species of the genus over more than twenty years but has only studied it intensively in Bolivia in the last few years. Herbarium material has been examined at BM, FCQ, K, and OXF in the United Kingdom, at BOLV, HSB, LPB, USZ in Bolivia and at GUAY, LOJA, Q, QCA and QCNE in Ecuador while extensive collections from Peru were loaned by the Field Museum (F) and the Missouri Botanical Garden (MO). A database of over 450 collections from Bolivia and Peru was built up and has allowed generalisations about distribution, habitat and flowering periods to be made. This paper would also have been much weaker without the help of many colleagues who provided collections and photographs, which serve to illustrate species in this paper. Reference has been made to relevant publications, particularly those of O'Donell (1950, 1960a, 1960b) and some recent publications from Brazil, especially Buril (2013), Buril et al. (2015), Pastore et al. (2017) and Moreira et al. (2018). Online images from Tropicos (https://www.tropicos.org/), the Field Museum (https://www.fieldmuseum.org/node/4781), Flora do Brasil 2020 under construction (http:// reflora.jbrj.gov.br/reflora/floradobrasil/), and especially Jstor (https://plants.jstor.org/) have been in-

Accepted for publication 18 November 2020. Published online 22 July 2021

1 Royal Botanic Gardens, Kew, Richmond, Surrey, TW9 3AB, UK.

2 Department of Plant Sciences, University of Oxford, South Parks Road, Oxford, OX1 3RB, UK. e-mail: jriwood@hotmail.com

3 University of Exeter, Stocker Road, Exeter, EX4 4PY, UK. 
valuable. The images of Jacquemontia on websites are usually readily identified.

The following account of the genus in Peru and Bolivia relies principally on morphological characters, a wide range of which have proved useful. They include habit (erect vs trailing or twining; herbaceous vs woody), indumentum and leaf shape, especially the base and the apex of the leaf, but leaf size is not without significance. The shape of the inflorescence is often significant, including the number of flowers and the degree of congestion, the shape, size and persistence of bracteoles, the shape, size, and indumentum of the inner and outer sepals, which may be similar or dissimilar, and the colour of the corolla and to a lesser extent its size. Few differences between species have been noted in the androecium or gynoecium and fruit characters have been little used, although they may prove to be useful when more fully known. In consequence they are not included in the diagnostic descriptions of known species.

Short, diagnostic descriptions are provided for all species except new taxa, which are described in full. Selected specimens are cited for all species except rarities and novelties, for which full citations are provided. Many species have been collected from the same location by different collectors and there seems little value in repeating these citations. At least one collection is cited from each province or department from where it is recorded

GeoCat (www. Geocat.kew.org/) has been accessed to calculate areas of occupancy and extent of occurrence but conservation assessments have not been made mechanically. Knowledge of individual populations and of known threats to particular areas or habitats have been used to interpret initial results obtained through GeoCAT. However, it is worth noting that assessments based on extent of occurrence seem to produce intuitively more accurate results than those based on area of occupancy, for example, the widespread and common Bolivian species, Jacquemontia evolvuloides (Moric.) Meisn. is classified as Least Concern (LC) based on extent of occurrence but Endangered (EN) based on an area of occupancy of $156,000 \mathrm{~km}^{2}$. Other similar conflicting examples include $J$. cumanensis (Kunth) Kuntze and J. lorentzii (Kuntze) Peter ex O'Donell. In many cases, perhaps all cases, our data is inadequate in one or more aspects including the probable number of locations and the size of individual populations. The assessments provided are essentially tentative and could be more accurate with robust population data and information on the current threats, something which is rarely available for tropical plants. Observations in the field in 2019 suggest that several species, notably Jacquemontia tamnifolia (L.) Griseb., may produce quantities of seed that lie dormant for many years until an environmental change, such as fire, stimulates germination. Assesssments are based on the presence of individual species in Peru and Bolivia separately and not on the plant's global distribution.

\section{Taxonomic Account}

Jacquemontia Choisy (1834: 476 [94])

Herbs or subshrubs, perennial in Bolivia and Peru (except Jacquemontia gracillima Hallier f.); stems trailing, decumbent, twining or erect; indumentum commonly of branched hairs. Leaves entire, oblong to ovate; inflorescence usually cymose but often contracted and subcapitate; sometimes racemose or loosely paniculate; calyx of five free sepals, sepals subequal or unequal, the two outer differing from the two innermost. Corolla blue or white (rarely pale pink), broadly funnel-shaped, glabrous on the exterior; stamens 5, included or very shortly exserted, white; pollen mostly pantocolpate, rarely tricolpate (J. nodiflora (Desr.) G.Don and J. sphaerocephala Meisn.); style 1; stigmas 2, ellipsoid to oblong, straight or bent, somewhat flattened, exceeding anthers; ovary bilocular, 4-ovulate. Capsule usually 4 - 8-valved, subglobose, glabrous; seeds glabrous, often verruculose, occasionally weakly winged.

As well as some variation in pollen structure (Buril 2013), Jacquemontia is noted for variation in the number of arms of the branched hairs present in many species. The number of arms is often reported to be species-specific but this is not always an easy character to see and, as most species are reported to have 3-armed hairs, it is of limited diagnostic value. Some species, J. evolvuloides and J. unilateralis, are known to be variable in hair type. Consequently, little emphasis has been given to this character, although it is mentioned in passing where it is significant.

Although long considered to be closely related to Convolvulus L., recent molecular studies (Stefanovic et al. 2002, 2003; Carine et al. 2004; Buril 2013) show that Jacquemontia is only distantly related despite the somewhat similar stigma structure, linear in Convolvulus but elliptic and somehat flattened in Jacquemontia. These same studies have confirmed the monophyly of Jacquemontia after the exclusion of one or two species, such as J. montana (Moric.) Meisn., but have not yet resulted in a clear infrageneric classification. As with Ipomoea L. (Muñoz-Rodríguez et al. 2019), it is clear that the long-accepted infrageneric classification based on inflorescence structure and dating back to Meisner (1869) cannot be accepted (Buril 2013) but a replacement is not easily established on the basis of our current information.

Although Peru and Bolivia are neighbours and have several species in common, their Jacquemontia flora is rather different as can be readily appreciated 
by a glance at the maps that accompany this paper. 23 species are recognised for Bolivia whereas only 12 are known from Peru, a striking difference, not the result of under-collecting in Peru but of the absence of the cerrado and chaco habitats found in eastern Bolivia.

In Bolivia and Peru, this genus is most likely to be confused with Evolvulus L. as both have small blue or white flowers. Evolvulus, however, never has twining stems with cordate leaves and can always be distinguished by the presence of a style divided at the base into two branches with linear or claviform stigmas. In Jacquemontia, there is a single unbranched style with two elliptic or oblong, often flattened stigmas.

DISTRIBUTION \& HABITAT. Most of the twining species are plants of open, often disturbed, bushy or grassy habitats. They are frequently found near settlements. The shrubby and erect species are found in forest or in open cerrados and show no propensity to grow near settlements. In Bolivia, the east is the most diverse in terms of species numbers although country endemics are entirely Andean. In Peru, the greatest diversity and endemism are in the dry north near the Ecuador border. The maps accompanying this paper show that even the more widespread species are scattered in their distribution and several (Jacquemontia blanchetii Moric., J. sphaerostigma (Cav.) Rusby, J. tamnifolia) are noticeably less common in Peru than in Bolivia. Indeed, the only really common species in Peru with 53 records is J. unilateralis (Roem. \& Schult.) O'Donell, which is locally abundant on the coastal lomas and western Andean foothills. The absence of $J$. evolvuloides from Peru is noteworthy given its widespread neotropical distribution, its abundance in parts of Bolivia (Map 9) and the presence of suitable habitats in Peru. The apparent absence of J. gabrielii (Choisy) Buril from the Andean foothills east of $\mathrm{La} \mathrm{Paz}$ is also noteworthy as it seems to have been replaced by J. acuminata Rusby in this region (Maps 1, 10).

PHENOLOGY. Most species flower during and just after the end of the rainy season so the best time to find species of Jacquemontia in flower is in the February June period. There are exceptions: J. gabrielii is a winter flowering species, which grows in moist forest, while J. selloi (Meisn.) Hallier f. flowers in spring after its grassy cerrado habitat is burnt.

NOTES. Jacquemontia is often seen as a difficult genus with poorly defined species. Although there is some truth in this, the difficulties have been exaggerated. Most specimens can be easily assigned to species if adequate material is available, but intermediates occasionally occur and some specimens are difficult to determine with confidence. White-flowered forms of normally blue-flowered species are not uncommon, hence the var. alba described for several species. Flower colour alone should be treated with caution when identifying species, although a particular colour is sometimes characteristic of a species.

\section{Key to species occurring in Bolivia}

1. Bracteoles large, $1-2.2 \mathrm{~cm}$ long, ovate, cordate, completely enclosing calyx; liana of dry bushland, even the

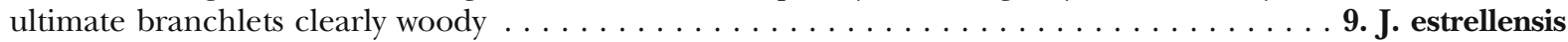
Bracteoles usually inconspicuous and less than $1 \mathrm{~cm}$ long, varied in form, but if large, neither cordate, nor completely enclosing the calyx; plant erect, trailing or twining, the ultimate branchlets herbaceous or only

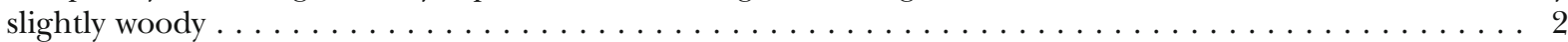

2. Decumbent perennial herb, villous in all parts, leaves subsessile, oblong-elliptic, acute at both ends; internodes short; inflorescence racemose $($ Huanchaca $\ldots \ldots \ldots \ldots \ldots \ldots \ldots \ldots \ldots \ldots$. . . . . . . 27. J. villosissima Twining or erect herb, glabrous or variously hairy but not villous in all parts, stems rarely decumbent; leaves

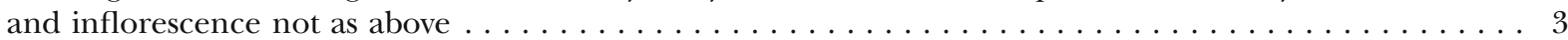

3. Inflorescence very lax and diffuse, cymes formed of $1-2(-4)$ flowers, often aggregated into a panicle-like structure; corolla bright blue, sometimes with reddish centre; stems usually with long white multicellular

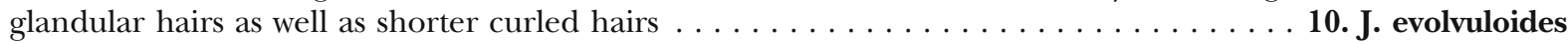
Inflorescence composed of $>3$ flowers in a dense to somewhat lax inflorescence; corolla blue or white, lacking a reddish centre; long multicellular hairs absent except in J. sphaerostigma . . . . . . . . . . . . . . . 4

4. Flowers in terminal heads; all vegetative parts tomentose (Huanchaca). . . . . . . . . . 22. J. sphaerocephala Flowers in axillary cymes, sometimes subcapitate in form; vegetative parts glabrous, pubescent or

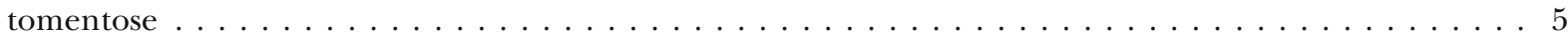

5. Outer sepals suborbicular, conspicuously accrescent in fruit; corolla white with purplish centre; usually annual herb of rock platforms and cerrado in eastern Bolivia . . . . . . . . . . . . . 14.J. gracillima Outer sepals variously shaped but not suborbicular, accrescent or not; corolla uniformly blue or white or white with lilac midpetaline bands; perennial herbs or subshrubs of varied habitats . . . . . . . . . 6

6. Erect or semi-erect subshrubs with woody stem $\ldots \ldots \ldots \ldots \ldots \ldots \ldots \ldots$

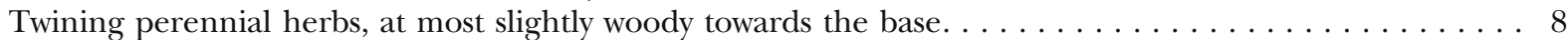

7. Stem and leaves roughly hirsute; cerrado species with annual stems arising from a woody xylopodium ... 21. J. selloi Stem and leaves sericeous or softly tomentellous; woody shrublet, lacking a xylopodium, growing in the inter- 
Andean dry valleys $\ldots \ldots \ldots \ldots \ldots \ldots \ldots \ldots \ldots \ldots \ldots \ldots \ldots \ldots \ldots \ldots$ chuquisacensis

8. Plant densely or sparsely covered in long spreading multicellular glandular hairs on vegetative parts.

Plant lacking long spreading glandular hairs $\ldots \ldots \ldots \ldots \ldots \ldots$

9. Sepals ovate, cordate, conspicuously accrescent in fruit . . . . . . . . . . . . . 6. J. cumanensis Sepals lanceolate, oblong-elliptic, obovate, or subrhomboid, not basally cordate and, except in J. lorentzii, not

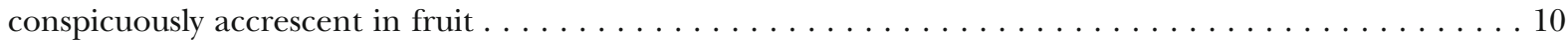

10. Cymes subsessile, dense, many-flowered, shorter than leaves; sepals $2-3 \mathrm{~mm}$ long; corolla white or white with

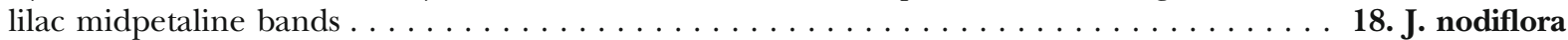
Cymes distinctly pedunculate, dense or lax; sepals $>3.5 \mathrm{~mm}$ long; corolla blue or white $\ldots \ldots \ldots$

11. Outer sepals glabrous, ciliate or with a few hairs on the abaxial surface $\ldots \ldots \ldots \ldots$ Outer sepals abaxially pilose, pubescent or tomentose, at least near the apex $\ldots \ldots \ldots \ldots$

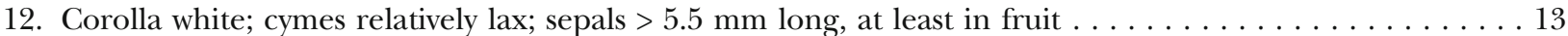
Corolla blue (very rarely white); cymes compact or lax; sepals $<5.5 \mathrm{~mm}$ long even in fruit . . . . . . . 14

13. Leaves with petioles $3-25 \mathrm{~mm}$ long, ovate-deltoid, apex shortly acuminate (Andes) . . . . . . 17. J. mairae Leaves subsessile with petioles $<5 \mathrm{~mm}$ long, oblong-elliptic, apex mucronate-cuspidate (cerrado). . . . . . . .

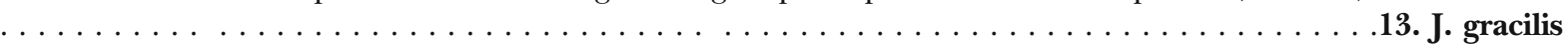

14. Sepals cuspidate; leaves large $(9-10 \times 6.5-8.5 \mathrm{~cm})$, ovate-suborbicular or subrepand, apex rounded and

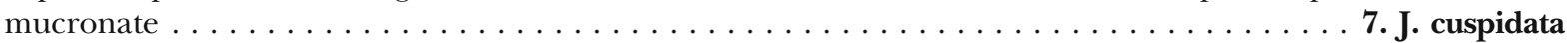
Sepals obtuse or acute, never cuspidate; leaves variously-sized, ovate, apex acute to acuminate . . . . . 15

15. Sepals elliptic-rhomboid, acute, papery; bracteoles persistent, prominent . . . . . . . . . 19. J. pentanthos Sepals ovate to oblong, obtuse to rounded, membranous; bracteoles caducous or inconspicuous. . . . . . 16

16. Sepals usually with marginal cilia, oblong, up to $5.5 \mathrm{~mm}$ long; cymes dense . . . . . . . . . 12. J. gabrielii Sepals completely glabrous, ovate, up to $4 \mathrm{~mm}$ long; cymes relatively lax . . . . . . . . . . 2. J. blanchetii

17. Sepals small, rounded, $<4 \mathrm{~mm}$ long, vegetative parts tomentose . . . . . . . . . . . . 26. J. velutina Sepals larger, acute to acuminate, $>5 \mathrm{~mm}$ long; vegetative parts variously hirsute . . . . . . . . . . 18

18. Inflorescence subcapitate, long-pedunculate, subtended by lanceolate, oblong, oblong-elliptic or ovate, foliose,

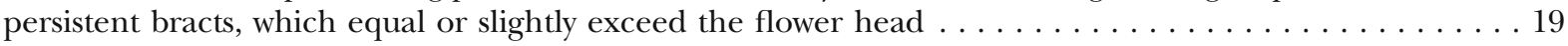
Inflorescence lax to dense, subtended by small, sometimes caducous bracteoles, usually much shorter than the

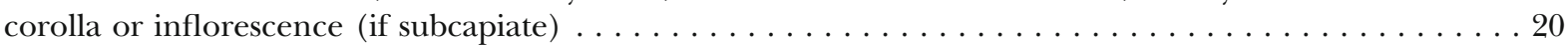

19. Sepals $8-12 \mathrm{~mm}$ long; pilose with long hairs; stem thinly pilose with long, spreading hairs (widespread

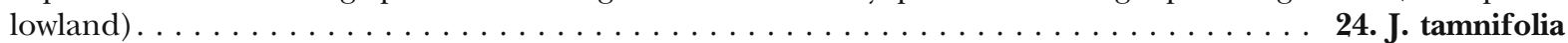
Outer sepals 5-8 mm long, tomentose; stem densely tomentose with curled hairs (Madidi) . 15. J. longipedunculata

20. Sepals broadly lanceolate to oblong-ovate or surhomboid, finely acuminate to a mucronate apex . . . . 21 Sepals ovate to elliptic or rhomboid, apex abruptly acute to mucronate $\ldots \ldots \ldots \ldots$

21. Sepals abaxially tomentose; leaves tomentose, retuse or shortly mucronate; bracteoles linear, caducous, $<4$ mm

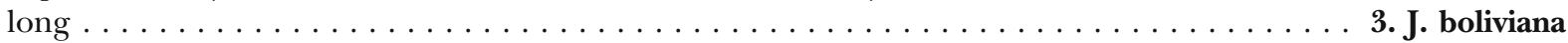
Sepals subglabrous below but thinly pubescent near apex; leaves glabrous or puberulent, acuminate; bracteoles filiform, persistent, 3 - $11 \mathrm{~mm}$ long, often exceeding flowers . . . . . . . . . . . . . . 1. J. acuminata

22. Inflorescence conspicuously bracteolate with numerous linear, oblong or oblong-lanceolate bracteoles; sepals


Inflorescence not conspicuously bracteolate; bracteoles caducous, but, if persistent, filiform or linear; sepals

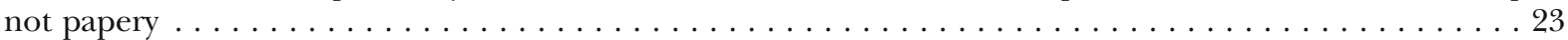

23. Sepals $3-4 \times 2-3 \mathrm{~mm}$ at anthesis, accrescent to $6 \times 5 \mathrm{~mm}$ in fruit; corolla $10-15 \mathrm{~mm}$, inflorescence relatively

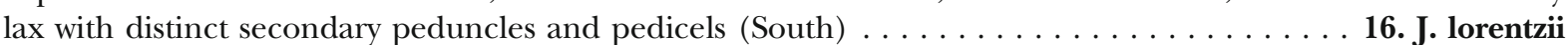
Sepals $(4-) 6-8 \times(3-) 4-5 \mathrm{~mm}$, not accrescent in fruit; corolla (13-) $15-25 \mathrm{~mm}$ long; inflorescence compact, secondary peduncles and pedicels short or nearly absent ( La Paz) . . . . . . . 25. J. unilateralis

\section{Key to species occurring in Peru (and Ecuador)}

1. Inflorescence subcapitate, long-pedunculate, subtended by lanceolate, oblong, oblong-elliptic to ovate foliose bracteoles, which equal or slighting exceed the flower head; sepals $8-12 \mathrm{~mm}$ long; pilose with

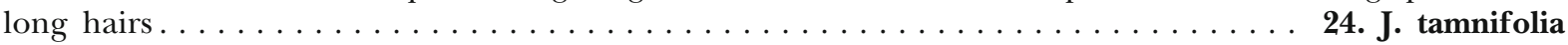


Inflorescence lax to subcapitate but not subtended by lanceolate or ovate foliose bracteoles; sepals $<8 \mathrm{~mm}$

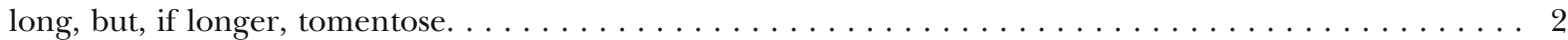

2. Plant densely or sparsely covered in long spreading multicellular glandular hairs on vegetative parts. ........ $\ldots \ldots \ldots \ldots \ldots \ldots \ldots \ldots \ldots \ldots \ldots \ldots \ldots \ldots \ldots \ldots \ldots \ldots \ldots$. sphaerostigma

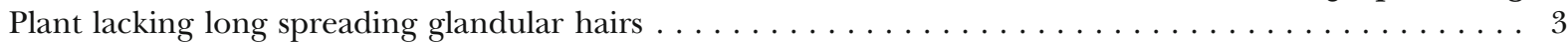

3. Cymes subsessile, dense, shorter than leaves; sepals $2-3 \mathrm{~mm}$ long; corolla white or white with lilac midpetaline

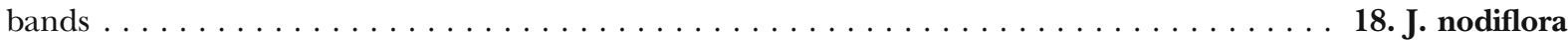
Cymes distinctly pedunculate, dense or lax, exceeding leaves; sepals $>2.5 \mathrm{~mm}$ long; corolla blue or white . . 4

4. Erect or semi-erect subshrubs with woody stems; sepals $2.5-3.5 \mathrm{~mm}$ long . . . . . . . . 11. J. floribunda Twining perennial herbs, only slightly woody at base ; sepals $>3.5 \mathrm{~mm} \ldots \ldots \ldots$

5. Sepals glabrous or with a few marginal cilia only $\ldots \ldots \ldots \ldots \ldots \ldots$

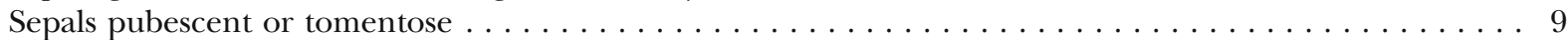

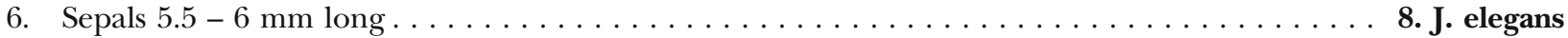

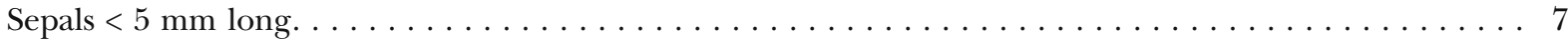

7. Sepals elliptic-rhomboid, acute, papery; bracteoles persistent . . . . . . . . . . . . . 19. J. pentanthos Sepals ovate to oblong, obtuse to rounded, membranous; bracteoles caducous . . . . . . . . . . . 8

8. Sepals usually with marginal cilia, oblong, up to $5.5 \mathrm{~mm}$ long; inflorescence usually dense . . . 12. J. gabrielii Sepals completely glabrous, ovate, up to $4 \mathrm{~mm}$ long, inflorescence usually lax . . . . . . . . . 2. J. blanchetii

9. Inflorescence conspicuously bracteolate with numerous, linear, oblong or oblong lanceolate bracteoles; sepals

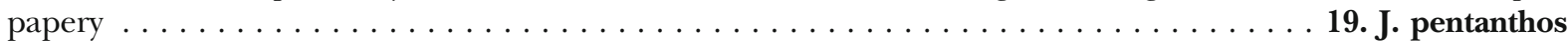
Inflorescence not conspicuously bracteolate; bracteoles caducous, but, if persistent, filiform or linear, few;



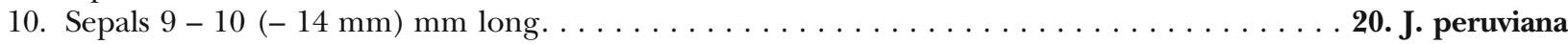

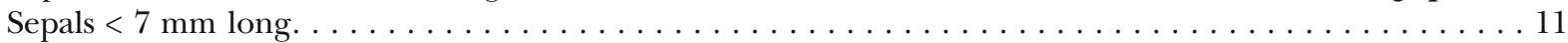

11. Sepals $3-5 \mathrm{~mm} \operatorname{long} \ldots \ldots \ldots \ldots \ldots \ldots \ldots \ldots \ldots \ldots \ldots \ldots \ldots \ldots \ldots$

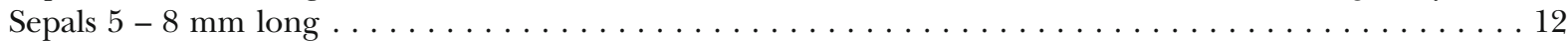

12. Sepals broadly (oblong-) lanceolate to ovate, finely acuminate to a mucronate apex . . . . 28. J. weberbaueri Sepals ovate to elliptic or rhomboid, abruptly acute to mucronate . . . . . . . . . 25. J. unilateralis

1. Jacquemontia acuminata Rusby (1896: 84). Type: Bolivia, "Espirito Santo", M. Bang 1263 (lectotype NY00319274 designated here, isolectotypes BR000008660183 , F-005493F, GH-00054629, K-000613126, M-0184752, MO-694363, NY-00319275, US-00111295, WIS-v0004389WIS).

Leaves pubescent, relatively large, mostly $8-12 \times 5-7 \mathrm{~cm}$, acuminate to fine point. Inflorescence of long-pedunculate, compact, usually many-flowered heads, the peduncle commonly bifurcate at base of head; secondary peduncles and pedicels short, $1-3 \mathrm{~mm}$; bracteoles $3-11 \times 0.5 \mathrm{~mm}$, linear-filiform, persistent; outer sepals $6-7 \times 1.5-2 \mathrm{~mm}$, narrowly ovate or lanceolate, long-acuminate, submucronate, glabrous and the apex usually pubescent, inner broader and shorter, ovate, mucronate $5 \times 2.5 \mathrm{~mm}$, glabrous, scarious (Fig. 11H); corolla $12-15 \mathrm{~mm}$.

DISTRIBUTION \& HABITAT. Endemic to northern Bolivia growing in the eastern foothills of the Andes in the Departments of La Paz and Beni (Map 1). It is a low altitude species of disturbed scrubby areas derived from seasonally dry forest found between 200 and $800 \mathrm{~m}$.

SELECTED SPECIMENS EXAMINED. BOLIVIA (11 seen). Beni: Est. Biol. del Beni, I. Guareco 461 (K, LPB);
Ballivian, Rurrenabague, S. G. Beck E B B. Steudel 30760 (K, LPB), Rio Maniqui, A. Parada et al. 1637 (K, MO, USZ). La Paz: Caranavi, J. R. I. Wood E D. Mondaca 14564 (K, LPB); Larecaja, Guanay, S. G. Beck 29482 (K, LPB), San Carlos, Mapiri, Buchtien 1221 (MO); Iturralde, Santa Fe, F. Zenteno 2631 (LPB).

CONSERVATION STATUS. Based on an extent of occurrence of $24,609 \mathrm{~km}^{2}$, this species would be classified as Near Threatened (NT) according to IUCN guidelines. This would seem the correct categorisation rather than that of Endangered (EN) based on an area of occupancy of $32,000 \mathrm{~km}^{2}$. Although there are rather few collections, its occurrence over a wide area and preferred habitat of disturbed bushy places would suggest that it is unlikely to be affected negatively by deforestation.

NOTES. Jacquemontia acuminata might be confused with J. corymbulosa but the larger leaves (twice the size), longer, glabrous (usually with pubescent apex) outer sepals up to $6 \mathrm{~mm}$ long (not $4 \mathrm{~mm}$ ) and prominent filiform bracteoles are distinctive. It can also be compared with J. martii Choisy but the larger leaves, denser, many-flowered cymes, more finely acuminate sepals and persistent filiform bracteoles serve to distinguish it. 


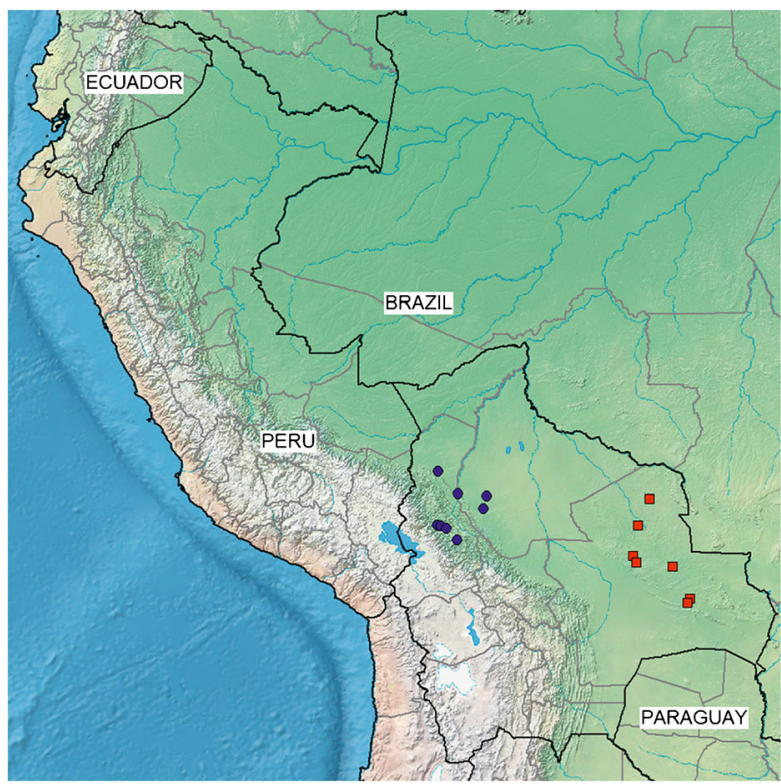

Map 1. Distribution of Jacquemontia acuminata $(\bullet)$ and J. gracillima ( $\mathbf{})$ in Bolivia.

We doubt very much whether the type locality (Espirito Santo in Cochabamba Dept.) is correct. Bang's localities are often doubtful, for example Bang 875 (Stenostephanus crenulatus (Britton ex Rusby) Wassh.) from "vic. Cochabamba" must be wrong as S. crenulatus is restricted to La Paz and Beni Departments. Another of Bang's problematic locations was previously discussed in relation to Clinopodium axillare (Rusby) Harley (Wood 2011).

S. G. Beck 9322 (K, LPB) from Caranavi, $18 \mathrm{~km}$ towards Coroico, at $970 \mathrm{~m}$, may belong to this species but the leaves and sepals are unusually small and the inflorescence few-flowered. More material is needed before it can safely be determined.

2. Jacquemontia blanchetii Moric. (Moricand 1838: 41). Type: Brazil, Bahia, Blanchet 564 (lectotype G-00222101, designated by Buril \& Staples 2018: 2, isolectotype BM-001217799).

Convolvulus blanchetii (Moric.) Steud. (Steudel 1841: 407).

Montejacquia blanchetii (Moric.) Roberty (1952: 32).

Convolvulus blanchetii forma albiflorus Kuntze (1898: 212). Type: Bolivia, [Ichilo] Yapacani, Kuntze s.n. (not found at NY).

Convolvulus blanchetii forma coeruleus Kuntze (1898: 212), nom. illeg., type form.

Ipomoea filipedunculata Rusby (1899: 150). Type: Bolivia, [La Paz, Larecaja], Guanai, H. H. Rusby 1997 (holotype NY-00319185).

A nearly glabrous twining plant with ovate, cordate, acute and mucronate leaves. Inflorescence somewhat lax, usually clearly cymose rather than umbelliform, often 6 - 15-flowered; peduncles commonly $<6 \mathrm{~cm}$ long; bracteoles linear-filiform, $1-3 \mathrm{~mm}$ long, inconspicuous; pedicels mostly $5-6 \mathrm{~mm}$; sepals completely glabrous, $3-4 \mathrm{~mm}$ long, rounded to obtuse, outer a little shorter than inner sepals. Corolla $1.5-2.3 \mathrm{~cm}$, pale blue, occasionally white. Fig. 1 .

DISTRIBUTION \& HABITAT. Endemic to southern South America, this is a lowland species usually found below $800 \mathrm{~m}$ but exceptionally reaching $1450 \mathrm{~m}$ in Bolivia. It is locally common in parts of northern Argentina, Paraguay, southern Bolivia and south and central Brazil. It becomes less common in the north of its range in northern Bolivia and Peru and appears to be absent from the Amazon basin and most of NE Brazil as well as Ecuador, Colombia and Venezuela. Map 2. SELECTED SPECIMENS EXAMINED. BOLIVIA. (55 seen). Beni: Cercado, Com. Ibiato, M. T. Martinez-Ugarteche 45 (USZ, K); Vaca Diaz, Hamburgo, D. Rocabado $\mathcal{F}^{2}$ E. Calzadilla 984 (USZ). Chuquisaca: Zudañez; ANMI El Palmar, J. Gutierrez et al. 2646 (HSB). La Paz: Larecaja, Guanai-Tipuani, M. Bang 1393 (BM, GH, K, MO); Nor Yungas, Milluguaya, Buchtien 606 (GH); Sud Yungas, Plazuela-Pasto Alto, J. R. I. Wood et al. 29187 (LPB, USZ). Santa Cruz: Ángel Sandoval: entre Propiedades Curichi and Palmita, north of San Fernando, M. T. Martinez-Ugarteche 338 (USZ); Chiquitos, Santiago, A. Krapovickas $\mathcal{E}$ A. Schinini 36466 (CTES, MO); Cordillera, Abapó-Izazog, S. G. Beck 6439 (USZ); Florida, Mataral, J. R. I. Wood et al. 22775 (K, LPB); Germán Busch, Cerro Mutún, D. Villarroel et al. 2054 (LPB, USZ); Guarayos: E of Ascención, N. Raes $\mathcal{E} C$. Terceros 173 (MO); Ibañez, Quebrada Salada, M. Nee

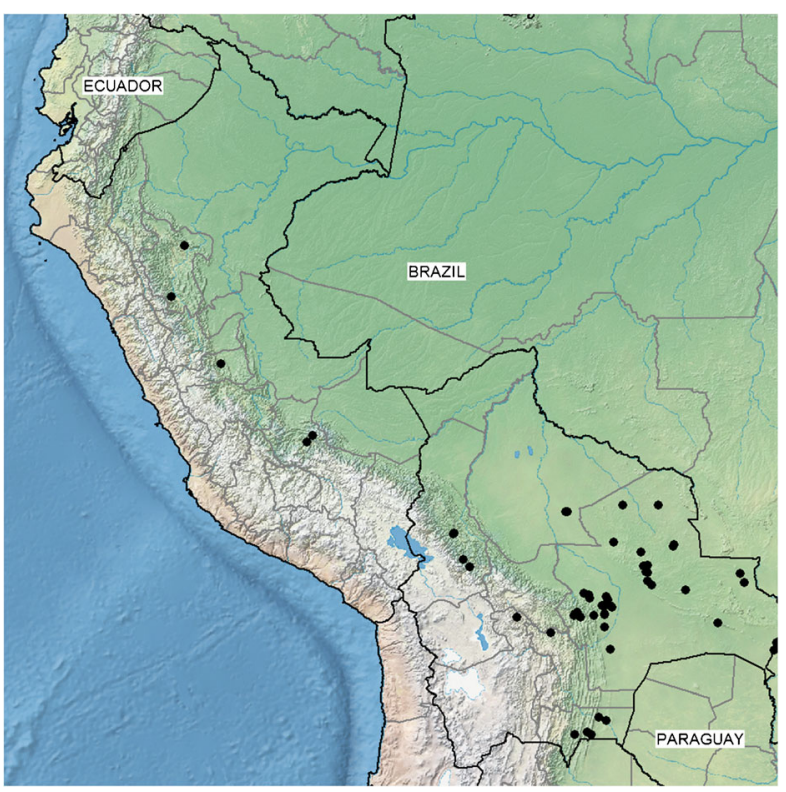

Map 2. Distribution of Jacquemontia blanchetii in Peru and Bolivia. 

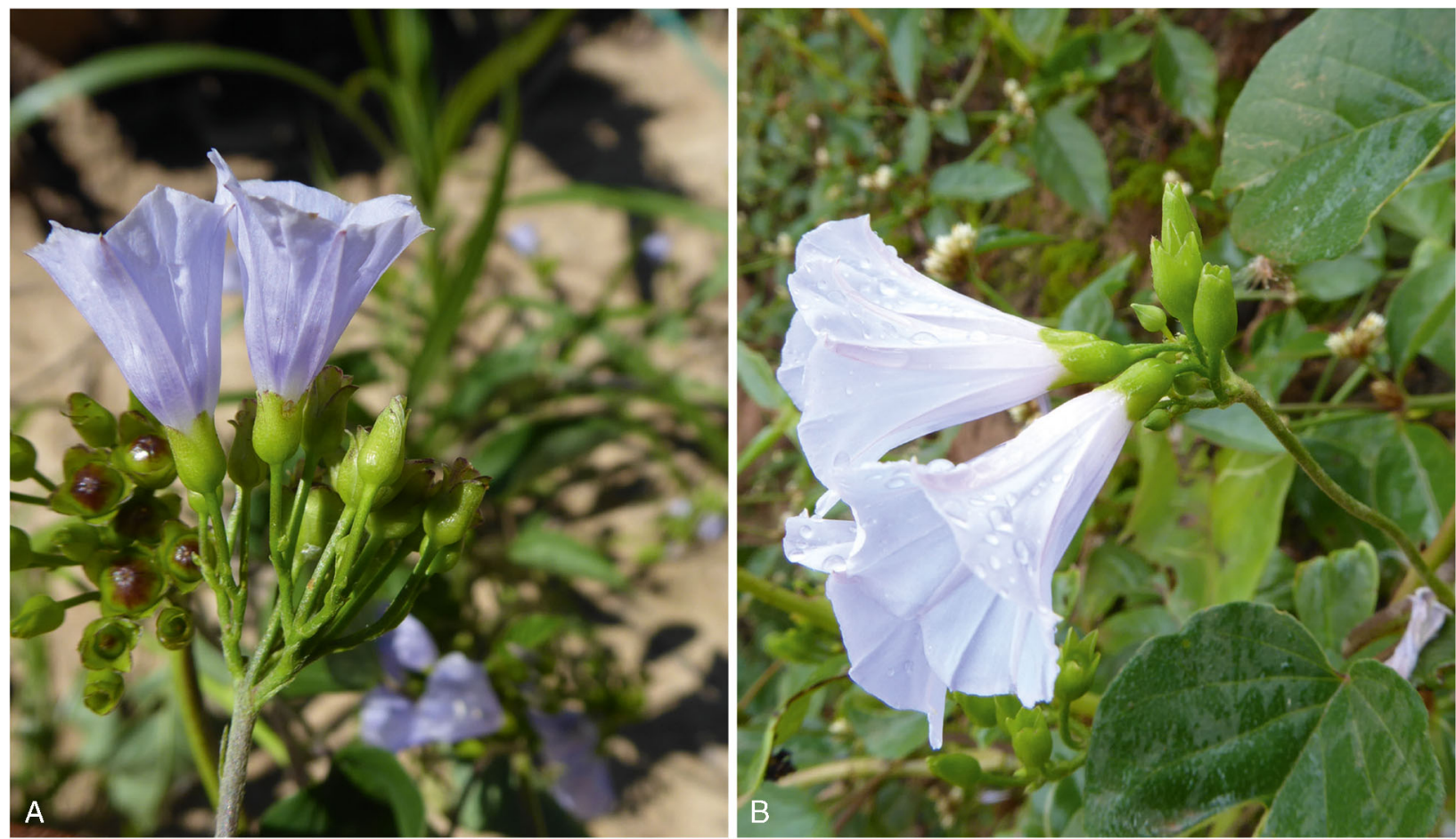

Fig. 1. Jacquemontia blanchetii. A inflorescence with sepals; B inflorescence with leaves. PHOTOS: A MAIRA TATIANA MARTINEZ; B DARWIN INITIATIVE PROJECT 16-004.

48775 (LPB, NY, USZ); Ichilo, Huaytú, J. R. I. Wood 13584 (K, LPB); Nuflo de Chávez, La Perseverancia, A. Gentry et al. 73862 (MO, USZ), El Cerrito, J. R. I. Wood et al. 28990 (USZ); Velasco, Carmen Ruíz, J. R. I. Wood et al. 28197 (K, LPB, USZ), Warnes, J. Tollervey 2157 (K). Tarija: Gran Chaco, Villamontes-Ibibobo, J. R. I. Wood et al. 28372 (K, LPB, USZ); O'Connor, Chuquiaca, K. Fiebrig 2720 (BM, K). PERU. (6 seen) Cusco: Convención, Papelpata, G. Calatayud et al. 2952 (MO, OXF). San Martín: Tarapoto, A. Mathews 1329 (K, OXF), R. Spruce 3924 (K).

CONSERVATION STATUS. Least Concern, even in Peru based on the wide extent of occurrence, exceeding the IUCN threatened threshold for criterion B.

NOTES. R. Chavez de Michel 704 (LPB) from Hac. Yabuimba, Alto Parapeti, Cordillera, Santa Cruz could be a form of Jacquemontia blanchetii but the sepals are muricate, shortly mucronate and with a few scattered hairs. Some flowers are unusually small. It was apparently a weed of cultivation and may represent a response to chemicals or be an undescribed taxon. Another apparently diseased form of $J$. blanchetii with minute flowers has also been found in Huayopata District near Cusco in Peru (E. Sucli et al. 3090 [MO]).

The relatively lax inflorescence of Jacquemontia blanchetii is shared with J. elegans and J. mairae and all three share a different facies from most other twining species. They appear to be related but no molecular studies carried out to date can confirm this.
3. Jacquemontia boliviana J.R.I.Wood, sp. nov. Type: Bolivia: Inquisivi, Huayra Pata, $2 \mathrm{~km} \mathrm{NE}$ of mouth of the Rio Aguilani at Lakachaka, $16^{\circ} 39^{\prime} \mathrm{S} 67^{\circ} 20^{\prime} \mathrm{W}, 2300$ m, 18 Nov. 1991, Marko Lewis 40564 (holotype LPB; isotypes $\mathrm{K}, \mathrm{MO}, \mathrm{OXF}$ ).

http:/ /www.ipni.org/urn:lsid:ipni.org:names:77216472-1

Perennial vine; stems twining, somewhat woody, tomentose. Leaves petiolate; lamina (1.5 -) $2.5-6 \times(0.8-)$ $1.5-4 \mathrm{~cm}$, ovate, base shallowly cordate, apex shortly mucronate with caducous mucro or retuse, margin entire, both surfaces tomentose; petioles $1-1.9 \mathrm{~cm}$, tomentose. Inflorescence of usually shortly pedunculate, compact cymes; with 4-10 flowers, subcapitate in form; peduncles 3.5 - 6 $(-10) \mathrm{cm}$, tomentose; outer bracteoles very narrowly lanceolate, $3-6 \times 1-2 \mathrm{~mm}$, caducous, secondary peduncles $0-2 \mathrm{~mm}$; bracteoles $3-4 \mathrm{~mm}$ long, linearfiliform, caducous; sepals unequal, $4-7 \times 3 \mathrm{~mm}$, somewhat accrescent in fruit, oblong-ovate to subrhomboid, acuminate, outer sepals abaxially tomentose, inner sepals scarious, glabrous apart from tomentose midrib area; corolla blue-purple or deep blue with darker, acute midpetaline bands, the exterior glabrous, c. $1.5 \mathrm{~cm}$ long; stamens included, filaments c. $5 \mathrm{~mm}$ long, glabrous, anthers oblong $1.2-$ $1.5 \mathrm{~mm}$; style $7-8 \mathrm{~mm}$ long, glabrous; stigma bilobed with $1 \mathrm{~mm}$ long elliptic lobes, ovary conical. Capsule rounded-ovoid, $5-6 \times 4 \mathrm{~mm}$, glabrous; seeds $2 \times 1.5 \mathrm{~mm}$, muricate. Figs 2 , 3A. 
RECOGNITION. Somewhat resembles Jacquemontia weberbaueri Helwig but differs in the tomentose (not pubescent) indumentum, the leaves rounded, mucronate or retuse with short caducous mucro, equally tomentose on both surfaces (not strongly mucronate, adaxially thinly pubescent except on veins), subcapitate inflorescence (not lax, well-branched inflorescence). Differs from J. longipedunculata in the caducous bracts and bracteoles, the latter only 3 $4 \mathrm{~mm}$ long (not $12-15 \mathrm{~mm}$ and overtopping the capitula), as well as the different shaped leaves (rounded and mucronate or retuse, not acute to a short mucro), oblong-ovate to subrhomboid and broadly mucronate (not narrowly acuminate). It also resembles $J$. velutina Choisy in the tomentose indumentum but differs in the much larger sepals.

DISTRIBUTION \& HABITAT. Restricted to Inquisivi Province in La Paz Department growing on the margins of 'Bosque Montano Subhúmedo de las Yungas' and in secondary scrub from $1340-2500 \mathrm{~m}$. Map 3.

SPeCIMENS eXAMINed. BOLIVIA. La Paz: Prov. Inquisivi, Lakachaka, trail from mouth of the Río Aguilani and the Fortaleza Choquecamiri, $16^{\circ} 40^{\prime} \mathrm{S} 67^{\circ} 20^{\prime} \mathrm{W}, 1650$ 1800 m, 23 Sept. 1991, M. Lewis 40433 (LPB, MO, OXF); Rio Khora, road between Playa Verde and Com. Khora, $30 \mathrm{~km} \mathrm{~N}$ of Choquetanga, $16^{\circ} 35^{\prime} \mathrm{S} 67^{\circ} 19^{\prime} \mathrm{W}$, 1500 m, 14 Nov. 1991, M. Lewis 40557 (LPB, MO, OXF); Huayra Pata, $2 \mathrm{~km} \mathrm{NE}$ of mouth of the Rio Aguilani at Lakachaka, $16^{\circ} 39^{\prime} \mathrm{S} 67^{\circ} 20^{\prime} \mathrm{W}, 2300 \mathrm{~m}, 18$ Nov. 1991, M. Lewis 40564 (LPB, MO, OXF); Chullpa Marka, $19 \mathrm{~km} \mathrm{~N}$ of Choqutanga, $16^{\circ} 41^{\prime} \mathrm{S} 67^{\circ} 20^{\prime} \mathrm{W}$, 1500 - 1900 m, 27 Nov. 1991, M. Lewis 40708 (LPB, MO); following Rio Churu from $200 \mathrm{~m} \mathrm{~W}$ of Aguilani, $3 \mathrm{~km} \mathrm{SE}$ of the ruins of Choquecamiri, $16^{\circ} 42^{\prime} \mathrm{S}$

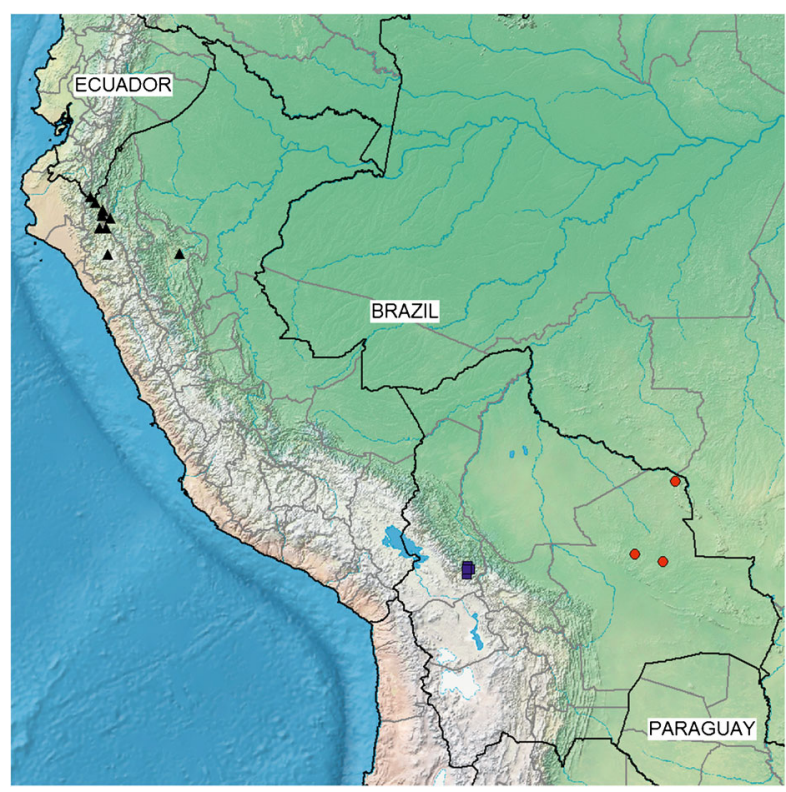

Map 3. Distribution of Jacquemontia boliviana ( $\mathbf{m}$ ) and J. gracilis (•) in Bolivia and J. weberbaueri ( $\mathbf{\Delta})$ in Peru. $67^{\circ} 20^{\prime} \mathrm{W}, 2400-2500$ m, 29 Nov. 1991, M. Lewis 40738 (LPB, MO, OXF). Com. Khora-Charrupampa, Rio Miguillas, $16^{\circ} 40^{\prime} \mathrm{S} 67^{\circ}$ 20'W, 1340 m, 29 Oct. 1994, N. Salinas 2941 (LPB); Com. Korra-Lakachaca, Rio Miguillas, $16^{\circ} 40^{\prime} \mathrm{S} 67^{\circ} 20^{\prime} \mathrm{W}, 1450 \mathrm{~m}, 30$ May 1994, N. Salinas 3052 (LPB); Entre Rios from Poque Logue to Alta Polea, $16^{\circ} 50^{\prime} \mathrm{S}, 67^{\circ} 20^{\prime} \mathrm{W}, 2400$ - 2770, 29 Dec. 1989, L. J. Dorr, L. C. Barnett E M. Lewis 6901 (LPB, OXF); in woodland just above Com. Polea, between Licoma and Cajuata, $16^{\circ} 41.049^{\prime} \mathrm{W}$ $67^{\circ} 14.30^{\prime} \mathrm{W}, 2490 \mathrm{~m}, 31 \mathrm{March}$ 2019, J. R. I. Wood, S. G. Beck Eं E. Mayta 29180 (LPB).

CONSERVATION STATUS. Based both on an area of occupancy $28,000 \mathrm{~km}^{2}$ and extent of occurrence of $139.448 \mathrm{~km}^{2}$ this species would be classified as Endangered (EN) using Criterion B. All collections were made in a very restricted area (Map 3) and most of the woodland has been cleared in the region so habitat quality is clearly in decline. On the positive side, this species seems to adapt well to disturbed bushy ground around fields in areas cleared of trees but always in the near vicinity of woodland relics.

NOTES. This species has a wide altitudinal range. The inflorescence is subcapitate, the bracts deciduous, if present, and the bracteoles inconspicuous, although moderately persistent. The whole plant is densely tomentose, rather like Jacquemontia velutina.

J. P. Schmit 88 (K, LPB) from Sud Yungas between Yanacachi and Chulumani at $860 \mathrm{~m}$ could be this species. The inflorescence is very long pedunculate (c. $15-18 \mathrm{~cm}$ ) and the leaves are densely tomentose.

4. Jacquemontia chuquisacensis J.R.I.Wood, sp. nov. Type: Bolivia, Chuquisaca, Boeto, near Puente Santa Rosa, $18^{\circ} 44.25^{\prime} \mathrm{S} 64^{\circ} 18.374^{\prime} \mathrm{W}, 939 \mathrm{~m}, 23$ March 2016, J. R. I. Wood 28129 (holotype USZ, isotypes FHO, K, LPB).

http://www.ipni.org/urn:lsid:ipni.org:names:77216473-1

Erect subshrub, mostly $30-50 \mathrm{~cm}$ high; stems woody below, sericeous, wine-coloured on side facing the sun, the indumentum persistent on older parts, the hairs simple and branched. Leaves petiolate; petioles $3-10$ $\mathrm{mm}$; lamina $2-4.2 \times 1.6 \times 2.8 \mathrm{~cm}$, ovate, base subcordate to truncate with rounded auricles, apex acute, shortly mucronate, both surfaces minutely tomentellous, abaxially paler. Flowers in solitary, axillary cymes arising from the upper leaf axils, forming a subcorymbose inflorescence, the cymes somewhat dense and manyflowered; peduncles $3-5.6 \mathrm{~cm}$, sericeous, erect; secondary and tertiary peduncles $5-13 \mathrm{~mm}$, sericeous; bracteoles linear, $1.5-4 \mathrm{~mm}$, persistent after the flowers have fallen; pedicels $1.5-2.5 \mathrm{~mm}$, sericeous; sepals unequal, outer $7-8 \times 2.5-3 \mathrm{~mm}$, ovate-subrhomboids shortly acuminate, tomentellous, inner $6-7 \times 2 \mathrm{~mm}$, 

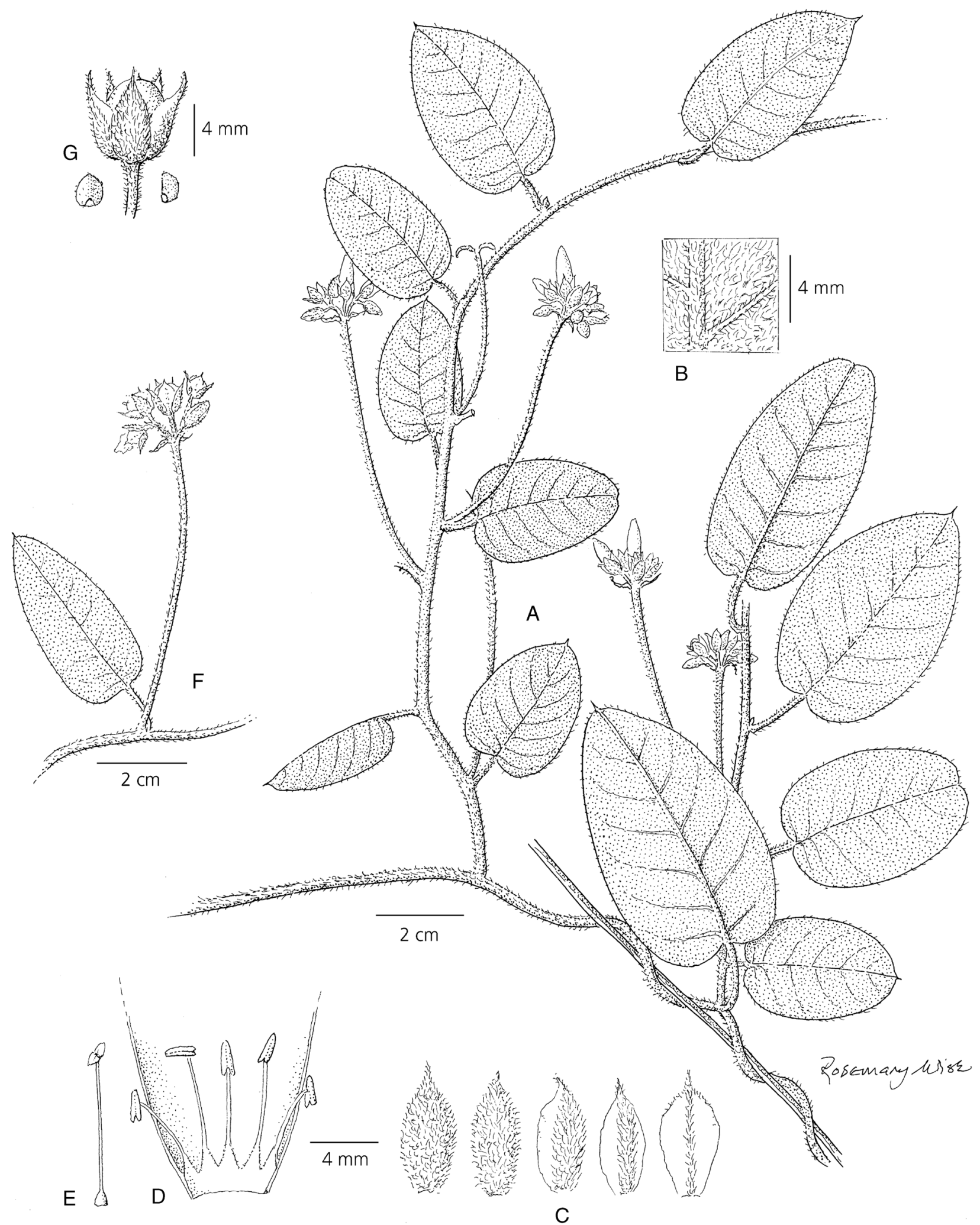

Fig. 2. Jacquemontia boliviana. A habit; B abaxial surface of leaf; C sepals, outermost (left) to innermost (right); D corolla opened up to show stamens; E ovary and style; F peduncle and fruiting inflorescence; G capsule and seeds. A - E, G from Marko Lewis 40564; F from Marko Lewis 40738. DRAWN BY ROSEMARY WISE. 


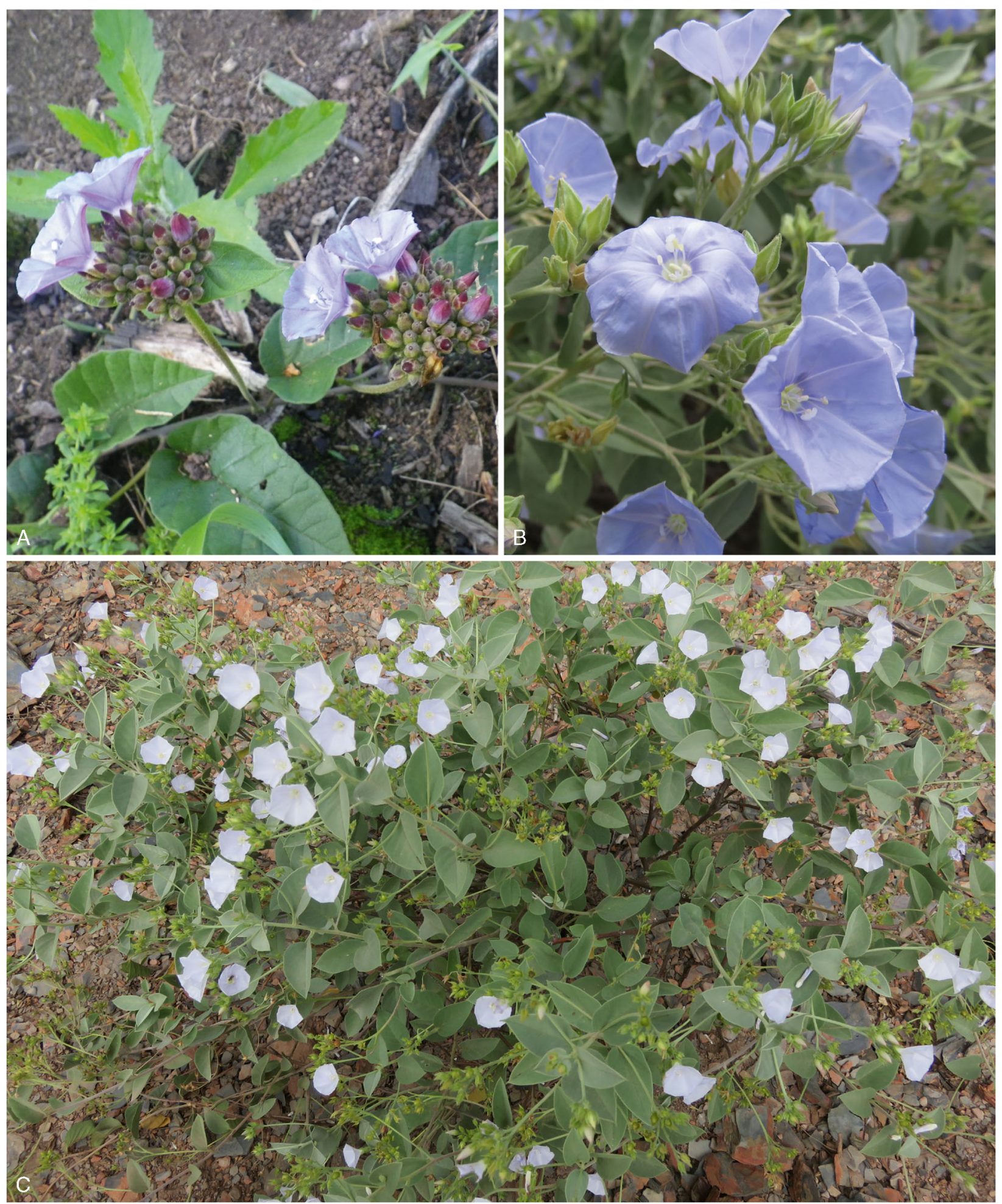

Fig. 3. A Jacquemontia boliviana; B - C J. chuquisacensis. PHOTOS: A JOHN WOOD; B - C JOHN PINK. 
lanceolate, acuminate, tomentellous but with glabrous scarious margins; corolla $1.4-1.6 \mathrm{~cm}$ long, campanulate, blue with white midpetaline bands or (rarely) white, glabrous; stamens included; filaments c. $4 \mathrm{~mm}$ long, anthers $0.75 \mathrm{~mm}$; style included, c. $5 \mathrm{~mm}$ long; stigmas elliptic, c. $1 \mathrm{~mm}$ long; ovary conical. Capsule ellipsoid, $4 \times$ $2 \mathrm{~mm}$, glabrous, enclosed by erect sepals, 1-seeded; seeds ellipsoid, pale brown $2.5 \times 2 \mathrm{~mm}$. Figs 3B, C; $4 \mathrm{~A}-\mathrm{K}$.

RECOGNITION. Resembles Jacquemontia floribunda (Kunth) Hallier f. in its erect habit and slightly unequal sepals but leaves ovate, $2-4.4 \mathrm{~cm}$ long up to 1.5 times as long as broad (not broadly lanceolate, 4 $-7 \mathrm{~cm}$ long, at least twice as long as broad), sepals 6 $8 \times 4 \mathrm{~mm}$, shortly acuminate, (not $2.5-3.5 \times 2.5 \mathrm{~mm}$, acute to obtuse), corolla c. $1.5 \mathrm{~cm}$ long (not $1.2-$ $1.3 \mathrm{~cm}$ long).

DISTRIBUTION \& HABITAT. A narrowly endemic species characteristic of steep loose shale and gravelly slopes around $900-1100 \mathrm{~m}$ in the Rio Grande Valley between Puente Santa Rosa and Nuevo Mundo. Although very locally frequent on the Chuquisaca side of the valley, its occurrence on the Santa Cruz side requiries confirmation as the coordinates of the Santa Cruz records suggest these records were, in fact, made in Chuquisaca. Map 4.

SPECIMENS eXAMINED. BoliviA. Chuquisaca: Boeto, between Nuevo Mundo and Puente Santa Rosa, 18 49'09"S 64'18'22"W, 985 m, 13 Dec. 2004, J. R. I. Wood Eं H. Huaylla 21180 (HSB, K, LPB); $30 \mathrm{~km}$ de Villa Serrano hacia el Río Grande, $18^{\circ} 49^{\prime} 19^{\prime \prime S}$ 64ำ18'23"W, 1033 m, 27 March 2013, J. R. I. Wood, D. Villarroel E B. R. M. Williams 27664 (K, LPB, USZ); near Puente Santa Rosa. $18^{\circ} 44.25^{\prime} \mathrm{S} 64^{\circ} 18.374^{\prime} \mathrm{W}, 939$

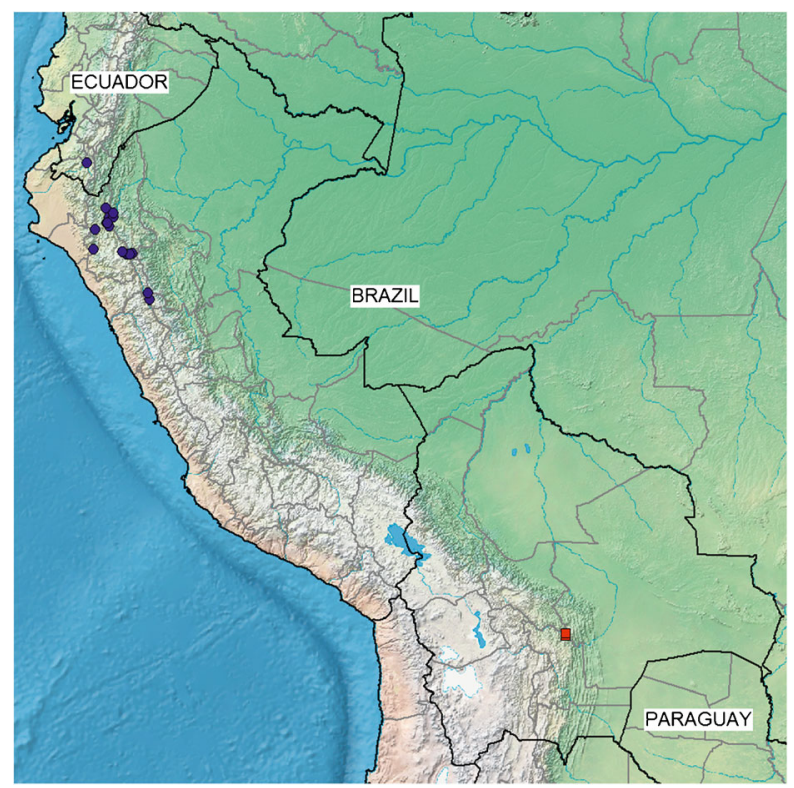

Map 4. Distribution of Jacquemontia chuquisacensis ( $\square$ ) in Bolivia and J. floribunda (•) in Peru. m, 23 March 2016, J. R. I. Wood 28129 (FHO, K, LPB, USZ). Santa Cruz: Vallegrande, near Puente Santa Rosa, $18^{\circ} 43^{\prime} 20^{\prime \prime S} 64^{\circ} 18^{\prime} 31^{\prime \prime W}, 938$ m, 29 Jan. 2013, G. A. Parada et al. 5234 (USZ); ibid., 18 $31^{\circ} 32^{\prime \prime S}$ 641''ㄹ"W, 1066 m, 4 Feb. 2013, G. A. Parada et al. 5448 (USZ).

CONSERVATION STATUS. This species is very restricted in its distribution being recorded from a very specific habitat from five nearby locations. Unlike most other endemics from this area, it has not been found in similar habitats elsewhere in the deep valleys of the Río Grande and Río Mizque valley system. On the positive side, there is little obvious risk to the habitat and the plant is not eaten by goats. Nevertheless, it should be provisionally categorised as Vulnerable (VU) D2 based on its very limited area of occupancy of $<20 \mathrm{~km}^{2}$ and the possibility that populations might be at risk from works involved in the proposed construction of a dam in the vicinity, although no current threat exists.

ETYMOLOGY. This species is named after the Bolivian department of Chuquisaca, to which it is nearly restricted (see above).

NOTE. The area in which Jacquemontia chuquisacensis grows is rich in endemic species including Bonamia riograndina J.R.I.Wood, Funastrum rupicola Goyder, Matelea sartago-diaboli Goyder, Gomphrena stellata Ortuño \& Borsch and Justicia aequilabris subsp. riograndina Wassh. \& J.R.I.Wood.

5. Jacquemontia corymbulosa Benth. (Bentham 1845: 137). Type: Ecuador, Puna, Guayaquil, Sinclair s.n. (lectotype K-000613122, designated here).

Jacquemontia guayaquilensis Meisn. (Meisner 1869: 297). Type: Ecuador [Guayas], Cerro de Santana, Guayaquil, Jameson 596 (lectotype NY00319287, designated here, isolectotypes K-000613120, US-00111319).

Jacquemontia azurea var. parviflora Choisy (1845: 397). Type: [Ecuador], Ruiz E Pavon s.n. (possible holotype G-00227359, possible isotypes K, OXF).

Twining herb with densely pubescent stems. Leaves shortly petiolate (usually $<1 \mathrm{~cm}$ long), lamina $2-6 \mathrm{~cm}$ long, ovate, cordate, rounded and mucronate, velvetytomentellous on both surfaces. Inflorescence dense, subcapitate, pedunculate, densely pubescent; peduncles $2.5-8 \mathrm{~cm}$, secondary peduncles $4-5 \mathrm{~mm}$; pedicels very short; sepals narrowly ovate, acuminate, $3-5 \times 1.5-3$ $\mathrm{mm}$, not accrescent; corolla c. $13-14 \mathrm{~mm}$ long, blue.

DISTRIBUTION \& HABITAT. Locally abundant in dry, coastal Ecuador especially around Guayaquil and north to Manabí but just extending south across the border into Peru, from where it is known from a single confirmed record. There has to be some doubt over the location of the Peruvian record as it is somewhat 


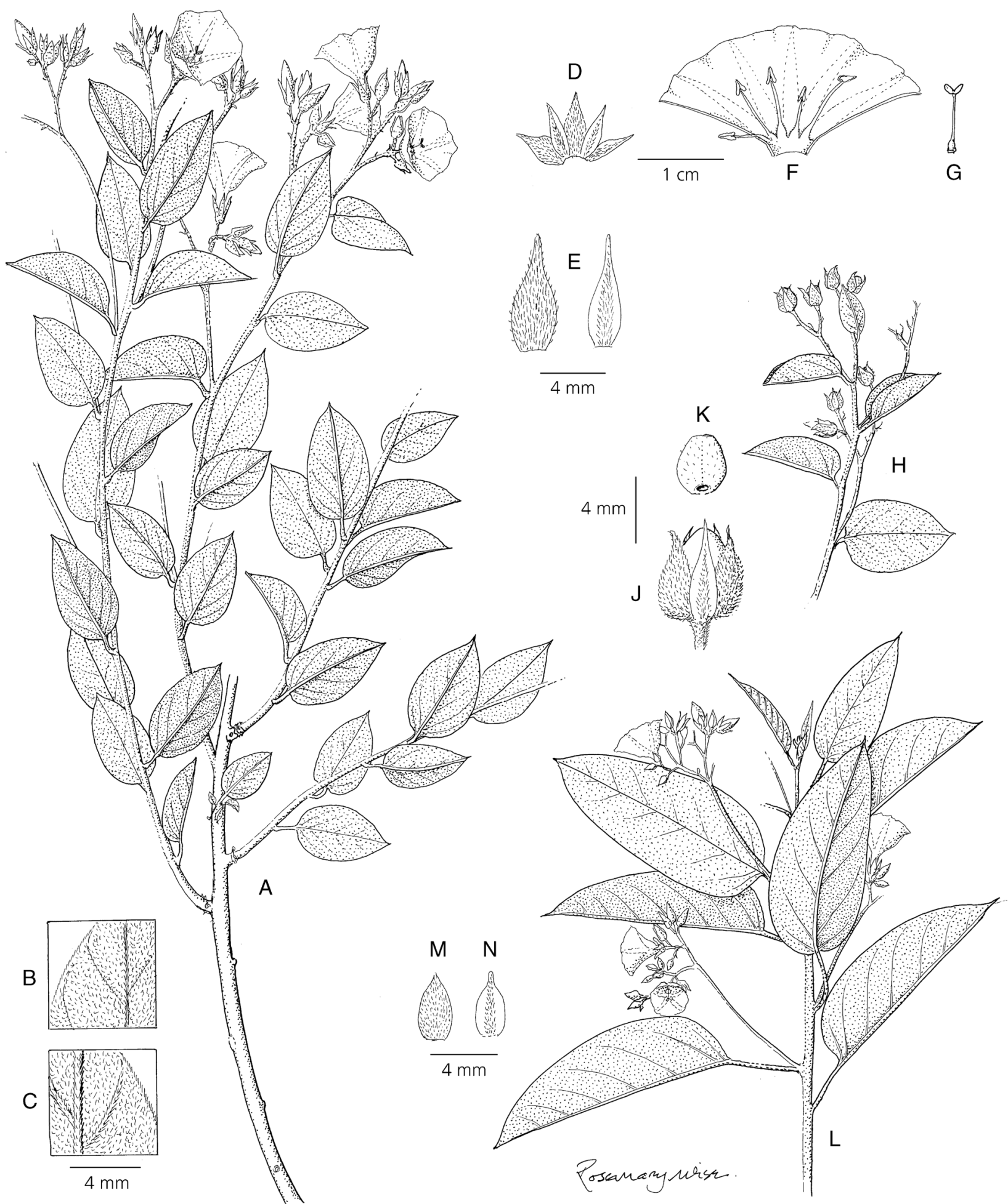

Fig. 4. Jacquemontia chuquisacensis: A habit; B adaxial surface of leaf; $C$ abaxial surface of leaf; D calyx; E sepals, outer (left), inner (right); $\mathrm{F}$ corolla opened up to show stamens; $\mathrm{G}$ ovary and style; $\mathrm{H}$ fruiting inflorescence; J capsule; $\mathrm{K}$ seed. J. floribunda: $\mathrm{L}$ habit; $\mathrm{M}$ outer sepal; N inner sepal. A - G from Wood 28129; H - K from Wood et al. 27664; L - N from Stein \& Todzia 2226. DRAWN BY ROSEMARY WISE. 
distant from the main population of Jacquemontia corymbulosa in Ecuador and the cited locality has been queried on the label suggesting that it might have been collected elsewhere. Map 5.

SPECIMENS EXAMINED. PERU. Tumbes: N of Quebrada Ampostura, 10 June 1977, P. L. Ames s.n. (F).

CONSERVATION STATUS. The single record would suggest that species should be categorised as Critically Endangered (CR) in Peru but nothing is known of the population so Data Deficient would be correct (DD). Jacquemontia corymbulosa is common in coastal Ecuador south of the equator.

TYPIFICATION. There are four sheets of Sinclair's collection of Jacquemontia corymbulosa from Guayaquil at Kew, two from Hooker's herbarium and two from Bentham's. All represent this species but the collection from Bentham's herbarium, seen by Austin and labelled by him as holotype is selected as the lectotype.

The specimen of Jacquemontia guayaquilensis at NY is selected as lectotype of that species as it appears to have been annotated by Meisner. Several isolectotypes are more complete specimens.

The possible holotype of Jacquemontia azurea var. parviflora Choisy at Geneva (G00227359) is not annotated by Choisy and does not indicate that it originates from Herb. Delessert, nor does the numbering coincide with that given in the protologue, but there seems to be no alternative type material at Geneva. The specimens at $\mathrm{K}$ and OXF probably belong to the same collection.

NOTES. As understood here, this species is almost endemic to Ecuador but its delimitation has been a matter of dispute. The record from Bolivia (Wood et al. 2015) is erroneous. Austin (1982a) included

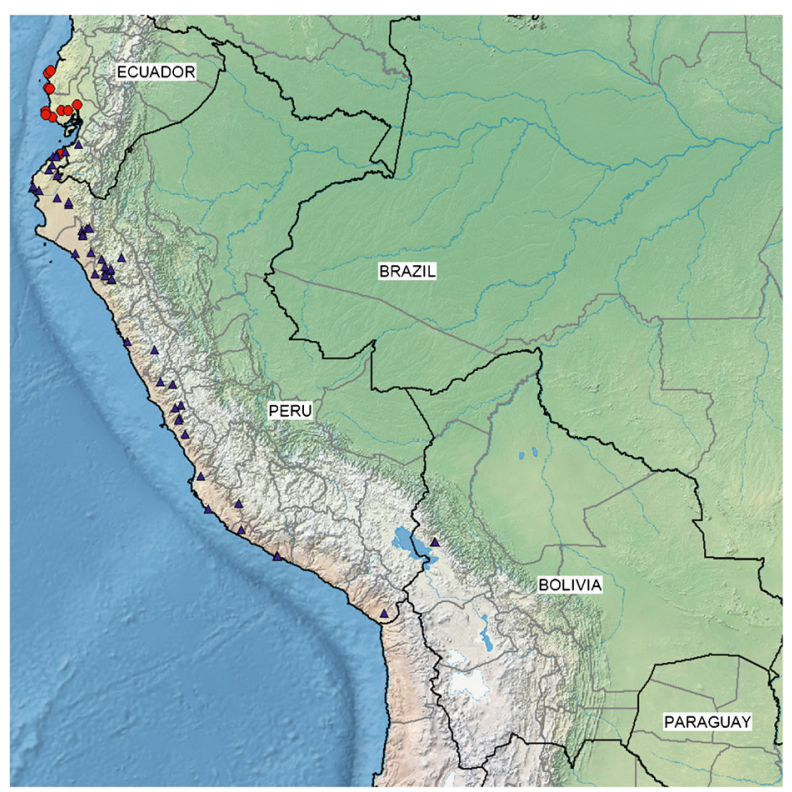

Map 5. Distribution of Jacquemontia corymbulosa (•) and J. unilateralis $(\boldsymbol{\Delta})$ in Bolivia, Peru and Ecuador.
Jaquemontia unilateralis (as J. prominens Helwig) within his concept of $J$. corymbulosa so extending its range to southern Peru. We think this was wrong as the two species are easily distinguished by the shape of the sepals, J. unilateralis having elliptic-rhomboid sepals. More recently $J$. corymbulosa has been recorded from eastern Brazil (Buril et al. 2015; Flora do Brasil 2020 under construction). We have not had the opportunity to examine material from Brazil named J. corymbulosa but the occurrence of this coastal Ecuadorian species in Brazil seems unlikely.

Jacquemontia corymbulosa superficially resembles J. acuminata from Bolivia but differs in the smaller (< $6 \mathrm{~cm}$ long) leaves with abruptly mucronate tips, much shorter, densely pubescent sepals and the absence of the long linear bracteoles characteristic of that species.

\section{Jacquemontia cumanensis (Kunth) Kuntze (1891:} 441).

Convolvulus cumanensis Kunth (1819: 99). Type: Venezuela, "in umbrosis Lagunae Chica, Golfo de Cariaco, Provinciae Cumanensis”, Humboldt $\mathcal{E}^{\circ}$ Bonpland s.n. (holotype P-00670743).

Convolvulus ferrugineus Vahl (1797: 17), non Jacquemontia ferruginea Choisy (1838). Type: Unknown location, Von Rohr 6 (holotype C-10009697, isotype BM- 000953203).

Ipomoea ferruginea (Vahl) Roem. \& Schult. (Roemer \& Schultes 1819: 240).

Dufourea heterantha Nees \& Mart. (Nees \& Martius 1823: 79). Type: Brazil, Wied s.n. (holotype BR0000006586249).

Jacquemontia heterantha (Nees \& Mart.) Hallier f. (1893: 543).

Aniseia heterantha Choisy (1845: 430).

Jacquemontia heterantha var. multiflora Hassl. (Hassler 1911: 194). Type: Paraguay, Cordillera de Altos, E. Hassler 2131 (syntypes K, MPU-011721, P-03849035).

Twining herb, the stems leaves and calyx tomentose; stems woody below; leaves shortly petiolate, ovate, cordate, shortly acuminate. Inflorescence of axillary pedunculate cymes; bracteoles linear c. $5 \mathrm{~mm}$; sepals unequal, outer sepals ovate, cordate, acute c. $10 \times 6-7$ $\mathrm{mm}$, strongly accrescent in fruit, inner sepals much smaller, c. $4 \mathrm{~mm}$ long; corolla blue. Fig. 5.

DISTRIBUTION \& HABITAT. In Bolivia and Paraguay this is a plant of the Chaco region, growing in sandy and stony ground in seasonally dry, often open bushland from $150-650 \mathrm{~m}$. In Bolivia, it is particularly characteristic of the Abayoy region around Taperas and Carmen Rivero Torres (Map 6). In Brazil it is mainly a plant of the caatinga in the north east; 

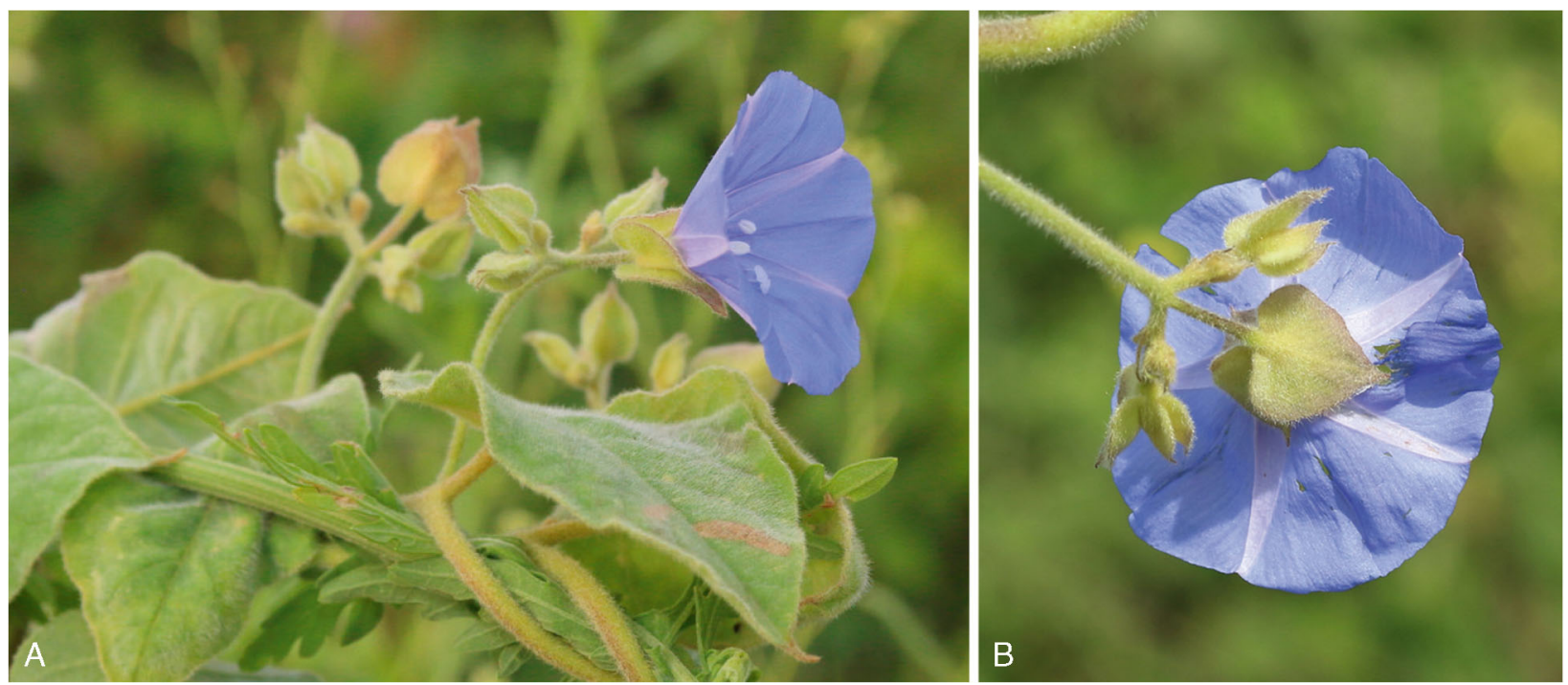

Fig. 5. Jacquemontia cumanensis. PHOTOS: ALEXANDER PARADA.

elsewhere growing in xerophytic vegetation of coastal Venezuela, neighbouring Guajira in Colombia and on the offshore Netherlands Antilles (Aruba, Curaçao) as well as in Puerto Rico and the neighbouring Virgin Islands.

SELECTED SPECIMENS EXAMINED. BOLIVIA (25 seen). Chuquisaca: Luis Calvo, Centro Experimental El Salvador, C. Saravia 11446 (LPB). Santa Cruz: Chiquitos, Quimome, J. R. I. Wood E F. Mamani 13500 (K, LPB, USZ), Candelaria, J. R. I. Wood et al. 28698 (K, LPB, USZ); Cordillera, Cerro Colorado, A. Gentry Ẽ R. Foster 75325 (USZ); Germán Busch, Carmen Rivero Torres-Santa Ana de Chiquitos J. R. I. Wood et al. 27894 (K, LPB, USZ), Cerro Mutún, D. Villarroel 2055 (MO, USZ). Tarija: Gran Chaco, Villamontes-Palos Blancos, J. R. I. Wood et al. 27591 (K, LPB, USZ), Villamontes-Ibabobo, J. R. I. Wood et al. 28373 (LPB, OXF, USZ).

CONSERVATION STATUS. Least Concern (LC), based on its extent of occurrence, would seem correct as this species is locally abundant in an unthreatened habitat. A categorisation of Endangered (EN) based on an area of occupancy of $88,000 \mathrm{~km}^{2}$ is quite wrong as the number of collections do not represent its real local abundance.

TYPIFICATION. No lectotype of Jacquemontia heterantha var. multiflora has been selected as no specimen from Geneva has been seen.

NOTES. As far as we know, Jacquemontia heterantha has never previously been treated as a synonym of J. cumanensis but there seems to be no morphological distinction between the two species so we have here adopted the older name. J. cumanensis was previously known only from the drier coastal area of Venezuela and dry areas of Puerto Rico and some of the Virgin Islands (Acevedo-Rodriguez \& Strong 2012). Although a distribution linking the chaco region, the caatinga of NE Brazil, Venezuela and the Caribbean is uncommon, it is not unique. Jacquemontia gracillima as well as Ipomoea longeramosa Choisy (Wood \& Scotland 2017b), I. incarnata (Vahl) Choisy (Wood et al. 2015) and I. megapotamica Choisy (Wood \& Scotland 2017a), show similar although not identical distribution patterns.

Rather oddly, this species was not recorded for Paraguay in the Catálogo de las Plantas Vasculares del Cono Sur (Austin \& Costea 2008) nor by Buril et al. (2015). At Corrientes (CTES) specimens of this species were identified as Jacquemontia lorentzii by Antonio Krapovickas. This is strange as both J. heterantha and J. cumanensis are older names. Most specimens of

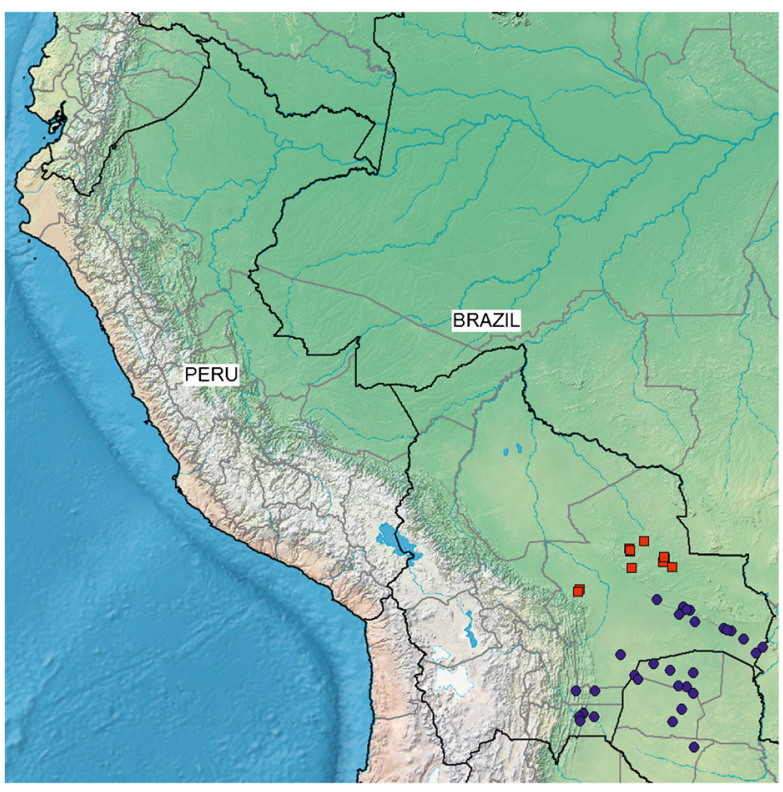

Map 6. Distribution of Jacquemontia cumanensis (•) in Bolivia and Paraguay and J. velutina ( $\mathbf{\square}$ ) in Bolivia. 
J. lorentzii and J. cumanensis are easily distinguished by the sepals, rhombic with cuneate base in the former, ovate, cordate in the latter, although some specimens with immature sepals can be difficult to name.

Besides older collections including Hassler 2131 and 12155, and Fiebrig 125 and 5992, there are many recent collections of this species from the Paraguayan Chaco. These records together with those from Bolivia suggest that the Chaco is one of its principal centres of diversity (Map 6). We have seen about 15 collections from Paraguay including the following:

PARAguay. Dept. Alto Paraguay: Cerro León, M. Quintana et al. 555 (CTES, PY); Lagerenza, M. Quintana et al. 657 (CTES, PY); Agua Dulce, F. Mereles 6611 (CTES, FCQ). Dept. Boquerón: Nueva Asunción, E. Garay et al. 3155 (PY); Est. Laguna Cristal, C. Vogt $\mathcal{E}$ F. Mereles 259 (CTES, FCQ); Parque Cue, G. Ramella 2331 (CTES, G).

7. Jacquemontia cuspidata J.R.I.Wood, sp. nov. Type: Bolivia, Chuquisaca, Zudañez, ANMI, El Palmar, Joya Charal, sector de Palmarcito K'asa, 0305073S 7948072W, 2090 m, 25 Nov. 2015, J. Gutiérrez, F. Prado, A. Paco Ẽ L. Ramos 2677 (holotype HSB, isotype fragment K).

http://www.ipni.org/urn:lsid:ipni.org:names:77216474-1

Twining perennial reaching $3 \mathrm{~m}$ in height; stems thinly puberulent. Leaves petiolate, $9-10 \times 6.5-8.5 \mathrm{~cm}$; ovate to suborbicular or subrepand, base truncate and very shortly narrowed onto the petiole, apex rounded and mucronate, margins ciliolate, adaxially nearly glabrous except towards the base, abaxially glabrous, paler; petioles $4-6 \mathrm{~cm}$, pubescent. Inflorescence of few-flowered, pedunculate axillary cymes; peduncles $11-12 \mathrm{~cm}$, puberulent; bracteoles $5-6 \times 0.5 \mathrm{~mm}$, linear, puberulent; pedicels $2-7 \mathrm{~mm}$, puberulent; outer sepals $5-6 \times 2$ $\mathrm{mm}$, strongly cuspidate, glabrous below, the apex pubescent, inner similar but only $4 \mathrm{~mm}$ long; corolla blue with cream centre, campanulate, $1.5-1.8 \mathrm{~cm}$ long; glabrous, stamens and style included; filaments very pale blue, c. $5 \mathrm{~mm}$ long; stamens and stigma white. Capsule and seeds not seen. Fig. 6 .

RECOGNITION. Apparently related to Jacquemontia lorentzii and J. pentanthos. Differs from the former in the persistent bracteoles and strongly cuspidate sepals which are only pubescent apically. Differs from the latter in the fewer, shorter bracteoles and the smaller, cuspidate sepals. Differs from both in the large, rounded mucronate leaves and few-flowered cymes. The sepal indumentum suggests a connection with J. acuminata but the cuspidate sepal shape is distinct.

DISTRIBUTION \& HABITAT. Steep stony slope in open dry forest with Berberis sp., Kagenackia lanceolata Ruiz \& Pav., Schinopsis marginata Engl. and Jacaranda mimosifolia D.Don, growing beside a track. Only known from the type location in ANMI El Palmar in Chuquisaca Department. Map 14.

SPECIMENS EXAMINED. BOLIVIA. Chuquisaca: Zudañez, ANMI El Palmar, Joya Charal, sector de Palmarcito
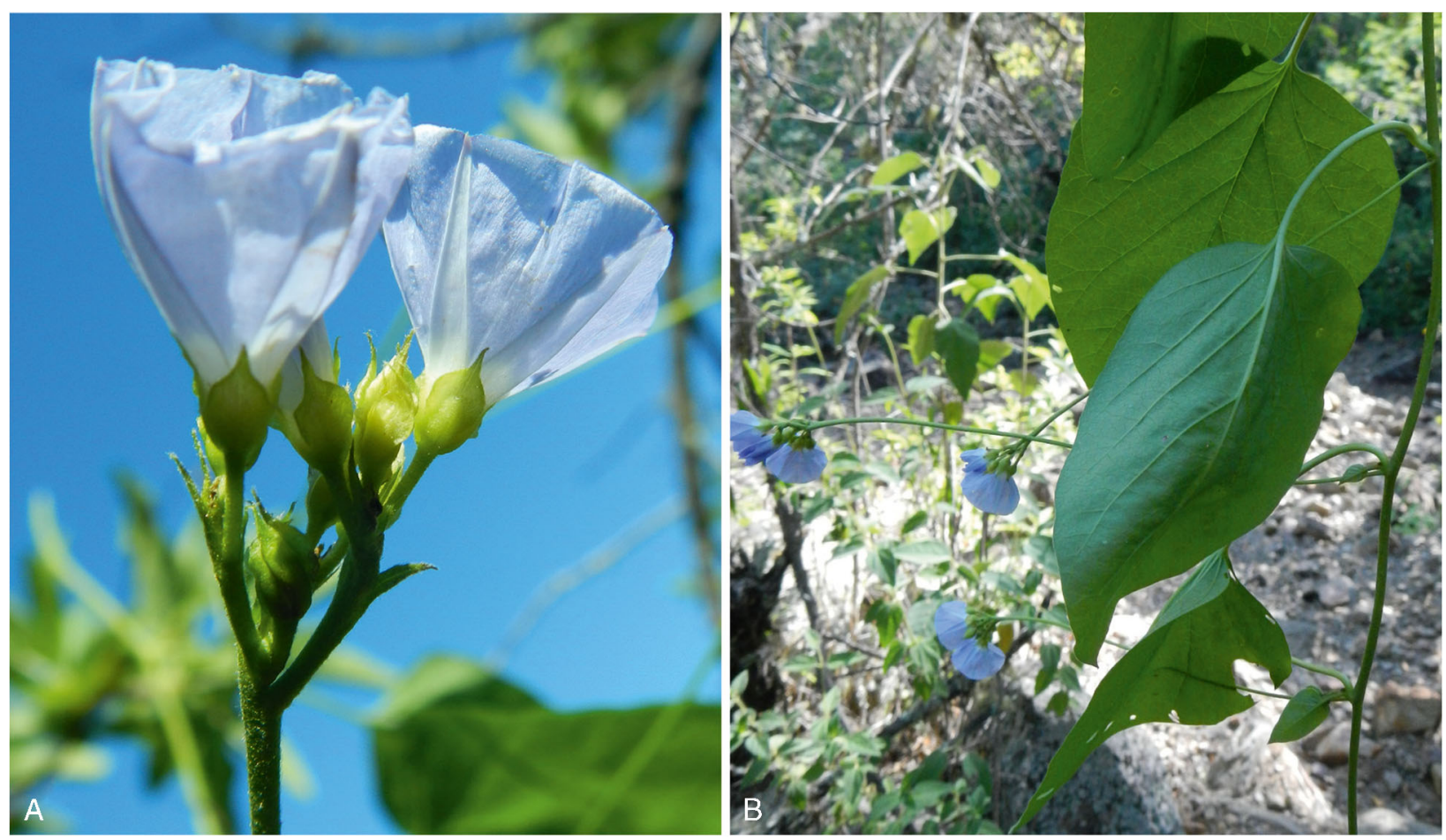

Fig. 6. Jacquemontia cuspidata. PHOTOS: JULIA GUTIÉRREZ. 
K'asa, 0305073S 7948072W, 2090 m, 21 Feb. 2015, J. Gutiérrez et al. 2677 (HSB).

CONSERVATION STATUS. The single record would suggest that this species should be categorised as Critically Endangered (CR) but nothing is known of the population so Data Deficient (DD) is currently the correct categorisation. The only known population lies within a protected area (Area Natural de Manejo Integral El Palmar) and no specific threat is known.

8. Jacquemontia elegans Helwig (1927: 1137). Type: Peru, Piura, Huancabamba, 1900 m, April 1912, A. Weberbauer 6058 (holotype $\mathrm{B} \dagger$, isotypes $\mathrm{F}$ F-0042382F, G-00227288, GH-00054634, U-0001417, US-000111307).

Jacquemontia parvifolia Helwig (1927: 1136). Type: Peru, Apurimac, Andahuaylas, left side of Apurimac valley, between Pachachaca and Pampas side streams, June 1911, A. Weberbauer 5878 (holotype $\mathrm{B} \uparrow$; isotypes F-F0042383F, GH-00054635).

Jacquemontia elegans var. parvifolia (Helwig) O'Donell (1960b: 77).

Robust twining herb; stems pubescent. Leaves with petioles $1-2 \mathrm{~cm}$ long; ovate, shallowly cordate, obtuse and mucronate, thinly to densely pubescent, especially abaxially, mostly rather small, $2-5 \mathrm{~cm}$ long. Inflorescence axillary, pedunculate, cymose; peduncles $3-10$ $\mathrm{cm}$; secondary peduncles $0.5-1 \mathrm{~cm}$; pedicels rather long, mostly $7-10 \mathrm{~mm}$; sepals ovate, to elliptic, obtuse, $4-7 \times 3-5 \mathrm{~mm}$ long, slightly accrescent in fruit, glabrous; corolla blue, $2-3 \mathrm{~cm}$ long. Fig. 7 .

DISTRIBUTION \& HABITAT. A species of dry rocky places with scrubby vegetation at relatively high altitudes recorded from between about 950 and $2500 \mathrm{~m}$. Its range extends from Peru through Ecuador to Colombia. In Peru, there are two disjunct populations, one in the Apurimac Valley region and the other in the dry Andes of northern Peru. Map 7.

SELECTED SPECIMENS EXAMINED. PERU (18 seen). Amazonas: Chachapoyas, P. C. Hutchison E J. K. Wright 5451 (F), Ubilón, R. Ferreyra 7108 (LIL). Apurimac: Andahuailas, Herrera 1493 (GH). Cajamarca: Cutervo, L. Sánchez Vega 5872 (F, MO), San Pablo, A. Sagastegui 15621 (F, MO). Cusco: Anta, W. Galiano $\mathcal{E} I$. Huamantupa 4642 (MO). Huancavelica: Mantaro Valley, A. Weberbauer 6519 (GH, US), Tayacaja, H. E. Stork E O. B. Horton 10441 (K). Piura: Huancabamba, C. Sandeman 4319 (K, OXF).

CONSERVATION STATUS. Within Peru this species is relatively widespread (Map 7) and should be categorised as Least Concern (LC) as the extent of occurrence exceeds the IUCN threatened threshold under criterion B.
NOTE. Macbride (1959: 518) suggested Jacquemontia parvifolia was a variant of J. blanchetii but O'Donell (1960b) correctly placed it with J. elegans. Some forms might be confused with $J$. blanchetii but the leaves are pubescent and the sepals and corolla are much larger. It generally grows at higher altitudes.

9. Jacquemontia estrellensis Krapov. (Krapovickas 2009: 61). Type: Argentina, Salta, Oran, $13 \mathrm{~km}$ E of Estrella, A. Krapovickas E J. G. Seijo 47679 (holotype CTES-0013269, isotypes NY-01843045, SP-001620).

Woody liana of dry bushland, the ultimate branchlets clearly woody, glabrous, younger stems tomentellous; leaves ovate or elliptic, mucronate, tomentellous. Inflorescence shortly pedunculate, axillary; peduncles 0 - $7 \mathrm{~mm}$; pedicels $1-3 \mathrm{~mm}$, flowers enclosed by a pair of enlarged, ovate, cordate, tomentellous bracteoles, these $1-2.2 \mathrm{~cm}$ long and completely enclosing the calyx; sepals narrowly ovate, acute, tomentose, $5 \mathrm{~mm}$ long; corolla 11 - $13 \mathrm{~mm}$, shortly exserted from bracteoles, glabrous. Fig. 8A.

DISTRIBUTION \& HABITAT. An uncommon plant of xerophytic scrub and dry woodland at low altitudes. It is known from the Chaco fringes of Argentina, Bolivia and Paraguay and the caatinga region of $\mathrm{NE}$ Brazil. In Bolivia, it is characteristic of the dry interAndean valleys between 900 and $1700 \mathrm{~m}$ in the valley of the Río Grande and Río Mizque and with a single record from Izazog in the Chaco at $400 \mathrm{~m}$. Map 8.

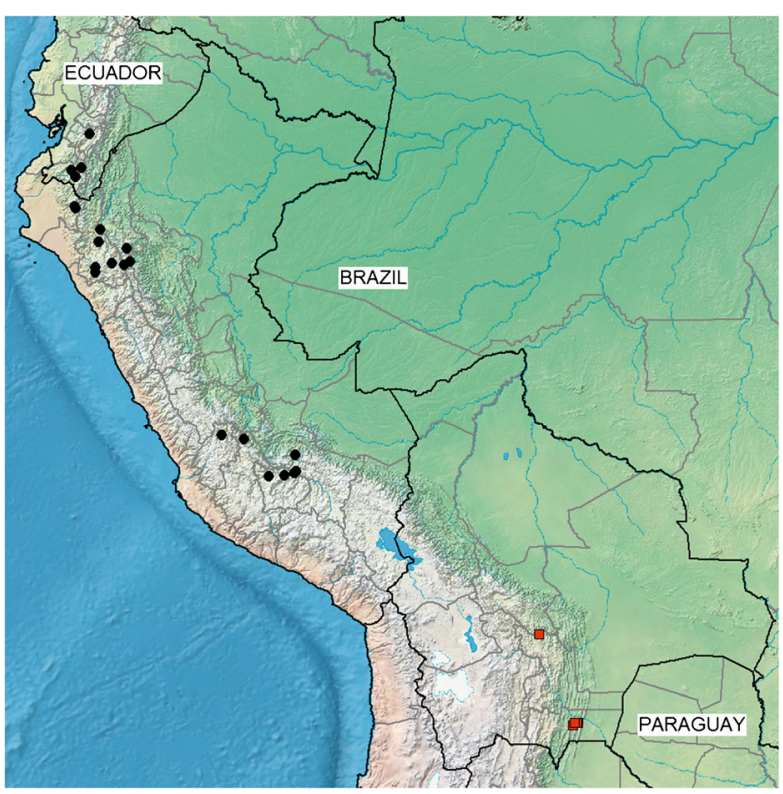

Map 7. Distribution of Jacquemontia elegans $(\bullet)$ in Peru and J. mairae ( $\mathbf{\square})$ in Bolivia. 


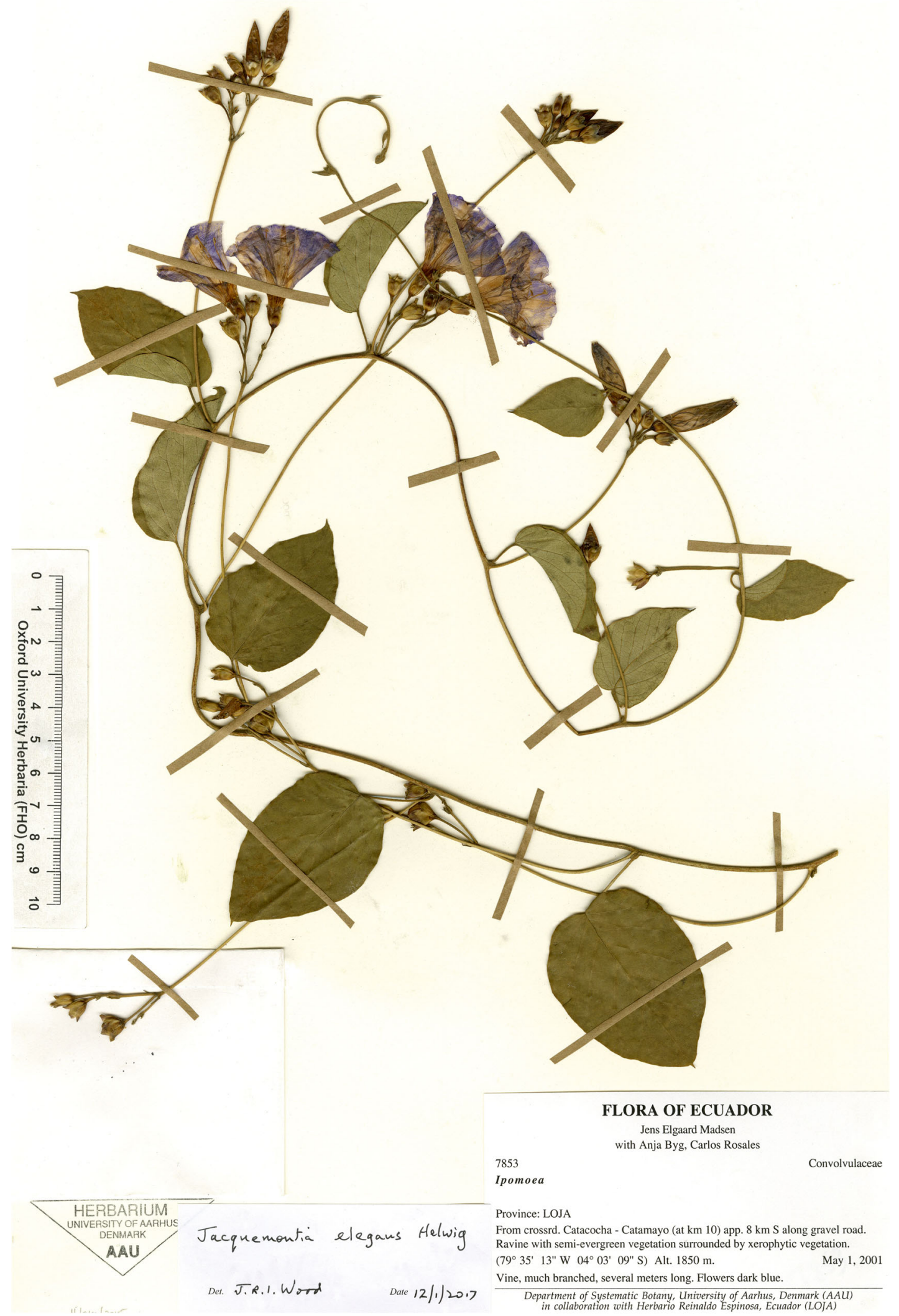

Fig. 7. Herbarium specimen of Jacquemontia elegans. PHOTO: JOHN BAKER. 
SELECTED SPECIMENS EXAMINED. BOLIVIA (10 seen). Chuquisaca: Zudañez, Río Grande Valley below Mojocoya, J. R. I. Wood E M. Serrano 13362 (HSB, K, LPB); Boeto, Río Grande Valley below Nuevo Mundo, J. R. I. Wood et al. 19594 (HSB, K, LPB). Cochabamba: Campero, Bellavista near Pasorapa, C. Antezana 622 (BOLV, MO). Santa Cruz: Caballero, Pulquina, M. Mendoza 2929 (K, USZ); Cordillera, Izazog, R. Chávez de Michel 2682 (LPB); Vallegrande, Pampa Negra, J. R. I. Wood et al. 27698 (K, LPB, USZ).

CONSERVATION STATUS. This species is conspicuous but nowhere common. Based on an area of occupancy of $36,000 \mathrm{~km}^{2}$, it should be classified as Endangered (EN) but a categorisation of Vulnerable (VU) based on the extent of occurrence of $6,505.910 \mathrm{~km}^{2}$ is more likely correct. Most, perhaps all locations where this species grows are unlikely to be affected by deforestation or agriculture. The main danger might come from goats eating young plants but seedlings are likely to be protected by cactus and other spiny shrubs, which are common in places where it grows. NOTE. Unique among South American species because of the large bracteoles which envelope the calyx and most of the corolla. Molecular studies (Buril 2013) somewhat unexpectedly suggest it is sister to Jacquemontia gracilis.

10. Jacquemontia evolvuloides (Moric.) Meisn. (Meisner 1869: 307).

Convolvulus evolvuloides Moric. (Moricand 1838: 48). Type: Brazil, cerca Bahia, Blanchet 1876 (lectotype G-00222066, designated by Pastore et al. (2017: 151, isolectotype $\mathrm{P}$ ).

Montejacquia evolvuloides (Moric.) Roberty (1952: 33).

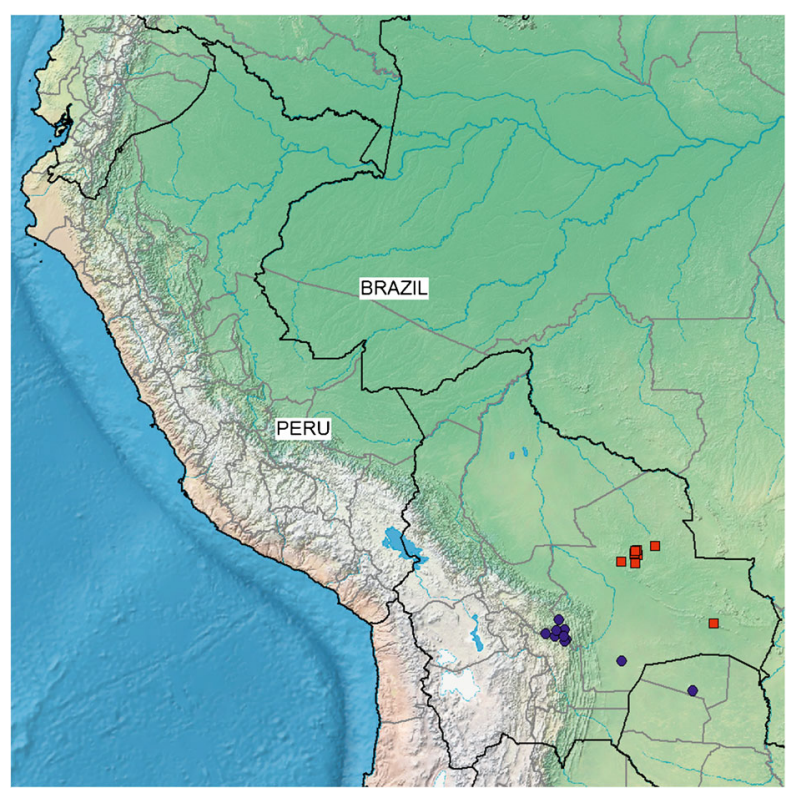

Map 8. Distribution of Jacquemontia estrellensis (•) in Bolivia and Paraguay and J. selloi ( $\mathbf{\square})$ in Bolivia.
Convolvulus agrestis Mart. ex Choisy (1845: 405). Type: Brazil, Bahia, Rio Sao Francisco, C. F. P. Martius s.n. (lectotype, M-0174135, proposed by Robertson (1971) and designated here, isolectotype, M-0174134).

Jacquemontia agrestis (Martius ex Choisy) Meisn. (Meisner 1869: 306).

Jacquemontia pedunculata Rusby (1896: 85). Type: Bolivia, Cochabamba, M. Bang 1067 (lectotype NY00336551, designated here, isolectotypes BM, BR000008660244, F-0054909F, K-000613118, MO694490, NY-00336552, US-00111318, WISv0004254WIS).

Short-lived perennial herb, plant very thinly to densely pilose with scattered, long multicellular white hairs, mixed with varying amounts of short sticky glandular hairs; stems usually trailing but occasionally climbing or twining on low shrubs; leaves usually small, usually 1 $-3 \times 0.8-2 \mathrm{~cm}$, ovate to elliptic, very shortly acuminate. Inflorescence loose, lax, often panicle-like; sepals 3-4 mm long, subequal, ovate, finely acuminate to apiculate, glandular-pubescent; cymes with 1 $2(-4)$ bright blue flowers, often with a reddish centre, $13-20 \mathrm{~mm}$ long. Fig. 8B,C.

DISTRIBUTION \& HABITAT. Locally common in dry areas of Central America from Arizona south to northern Colombia and Venezuela; largely absent from equatorial regions including Peru but widely distibuted in dry areas of southern Bolivia, northern Argentina, eastern Paraguay and central and north eastern Brazil. In Bolivia, it is frequent in sandy areas of the Santa Cruz lowlands including much of the Chiquitania but is also frequent in the dry inter-Andean valleys of the Río Grande catchment area reaching about $2600 \mathrm{~m}$ near Quillacollo. Map 9.

SELECTED SPECIMENS EXAMINED. BOLIVIA (41 seen). Chuquisaca: Boeto, Nuevo Mundo-Santa Rosa, J. R. I. Wood E H. Huaylla 21183 (HSB, K, LPB); Oropeza, Rio Chico Valley, J. R. I. Wood 11867 (K, LPB). Cochabamba: Campero, Villa Granada, J. R. I. Wood et al. 21707 (BOLV, K, LPB); Mizque, Tintin-Raqay Pampa, J. R. I. Wood E H. Huaylla (HSB, K, LPB); Quillacollo, Río Rocha gorge, J. R. I. Wood 11753 (K, LPB). La Paz: Iturralde, Pampas del Madidi, B. Torke Ẽ J. Valda 594 (LPB). Santa Cruz: Ángel Sandoval, San Fernando-Pozone, S. G. Beck 27976 (LPB); Caballero, Saipina, J. R. I. Wood E M. Mendoza 19139 (BOLV, K, LPB); Chiquitos, Roboré, J. R. I. Wood et al. 23784 (K, LPB, UB, USZ); Cordillera: Ipita, J. R. I. Wood et al. 28391 (LPB, OXF, USZ); Germán Busch, Rincón del Tigre, J. R. I. Wood et al. 28760 (K, LPB, USZ); Florida, Surtidor-Quirasillas, J. R. I. Wood et al. 24067 (K, LPB, UB, USZ); Nuflo de Chávez, Lomerio, M. T. MartinezUgarteche 30 (K, USZ); Vallegrande, Puente Santa Rosa, A. Parada et al. 5232 (MO, USZ); Velasco, laja near San 


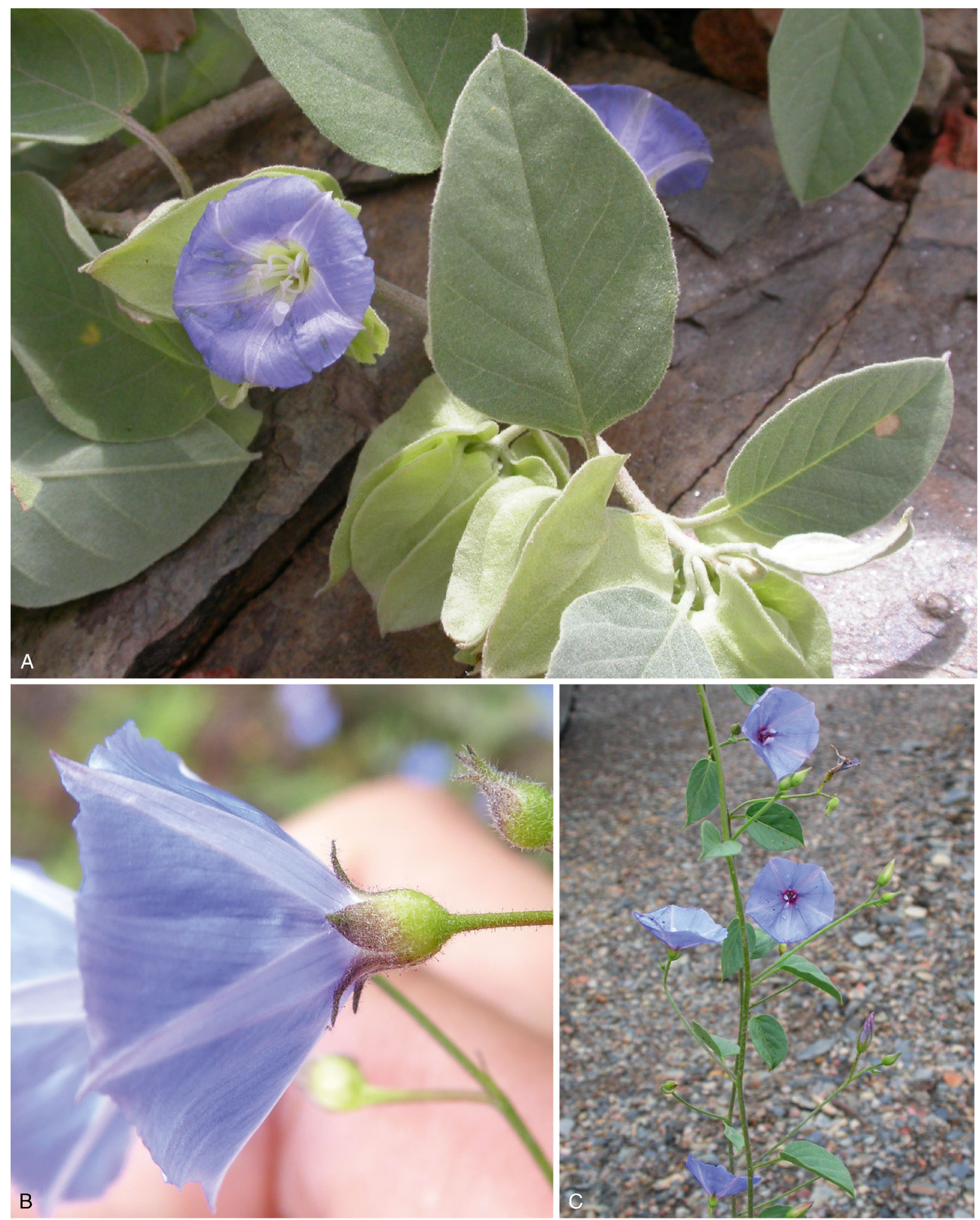

Fig. 8. A Jacquemontia estrellensis; B - C J. evolvuloides. PHOtos: A, C DARWIN InITIATIVE PROJeCt 162/11/010; B MAIRA TATIANA MARTINEZ. 
Martín, J. R. I. Wood et al. 26117 (K, LPB, UB, USZ); Flor de Oro, T. Killeen Ẽ J. Wellens 6639 (MO, USZ). Potosí: Charcas, Rio Caine, J. R. I. Wood et al. 23243 (BOLV, K, LPB).

CONSERVATION STATUS. This is a locally common and quite widespread species in Bolivia (Map 9) and should be classified as Least Concern (LC) based on its extent of occurrence.

NOTES. For full extra-Bolivia synonymy, see Pastore et al. (2017). Although Pastore et al. ascribe the lectotypification of Convolvulus agrestis to Robertson (1971), this work is an unpublished PhD thesis. In order to avoid any uncertainty about the validity of the lectotypification, M-0174135 is formally designated here as lectotype of Convolvulus agrestis.

The corolla is often reddish in the centre and the indumentum is very variable both in the amount and form of the hairs. Molecular studies (Buril 2013) suggest, unsurprisingly, that this species is closely related to Jacquemontia sphaerostigma.

\section{Jacquemontia floribunda (Kunth) Hallier f. (1893:} 543).

Convolvulus floribundus Kunth (1819: 96). Type: Peru,

[Cajamarca, Jaén], Tomependa, "in ripa fuminis Amazonum", Bonpland E̋ Humboldt 3596 (holotype $\mathrm{P}-00670735)$.

Ipomoea floribunda (Kunth) G.Don (1838: 267).

Erect branched subshrub $50-100 \mathrm{~cm}$ high. Leaves broadly to narrowly ovate, $3-8 \times 1.5-3 \mathrm{~cm}$, obtuse and shortly mucronate, both surfaces softly tomentellous. Inflorescence of pedunculate, dense to lax, axillary cymes; peduncles $1-6 \mathrm{~cm}$; sepals narrowly elliptic

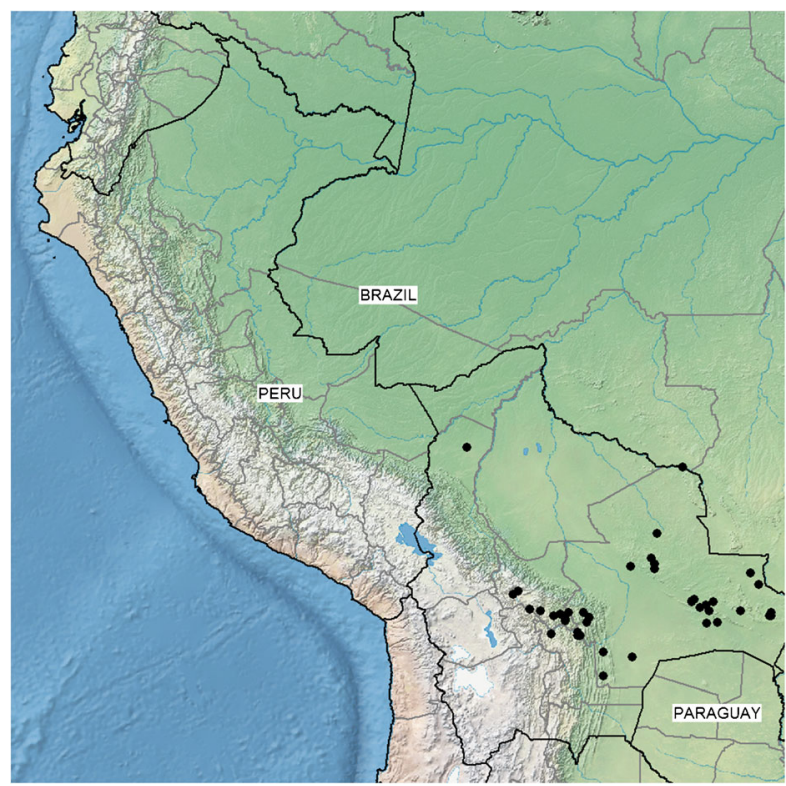

Map 9. Distribution of Jacquemontia evolvuloides in Bolivia.
$2.5-3.5 \times 2-2.5 \mathrm{~mm}$, obtuse, outer tomentose, inner tomentose only in central part; corolla $1.2-1.3 \mathrm{~mm}$. Fig. $4 \mathrm{~L}-\mathrm{N}$.

DISTRIBUTION \& HABITAT. Almost endemic to NW Peru but just entering Loja (Cornejo E Bonifaz 2173 [QCNE]; Jaramillo $\mathcal{E}$ Winneskjold 5822 [QCA]) in Ecuador. The record from Venezuela (Austin 1982b) is probably an error. It is a plant of dry forest and xerophytic scrub, mostly in the Marañón Valley region, usually found between 500 and $1000 \mathrm{~m}$, but occasionally reaching higher altitudes, especially in La Libertad where it is recorded at $2100 \mathrm{~m}$. Map 4.

SELECTED SPECIMENS EXAMINED. PERU (22 seen). Amazonas: Cumba, R. Vasquez et al. 27141 (MO); Bagua, El Milagro, R. Rojas et al. 9-1 (MO); Moyobamba - Bagua road, T. B. Croat 58299 (MO, OXF). Cajamarca: Jaén, Rio Chinchipe, A. Weberbauer 6229 (F, GH, US); Olmos to Pucara, T. Plowman et al. 14220 (F); Celendín, Balsas, P. C. Hutchison E. J. K. Wright 5427 (K, UC); Santa Cruz-Chiclayo, J. Mostacero et al. 1773 (F). La Libertad: Trujillo, entre Chagual y Retamas, A. López 8280 (MO).

CONSERVATION STATUS. This species is locally common in parts of northern Peru and is best classified as Near Threatened (NT) based on its extent of occurrence of $23,346.778 \mathrm{~km}^{2}$. It is essentially a plant of the Marañón valley region, which might face some threat from habitat fragmentation and the construction of dams to produce hydroelectricity (Marcelo-Peña et al. 2016). This threat may not be serious for this locally common species but evaluation of its populations will be needed to confirm this.

NOTE. Jacquemontia floribunda is the only erect subshrub amongst the Jacquemontia species that grow in Peru. Based on its similar morphology, it appears to be related to J. chuquisacensis from Bolivia but the sepals are almost half the size and narrowly elliptic rather than subrhomboid and the corolla is distinctly smaller. J. floribunda usually has larger, more cordate leaves although this is not consistent. Molecular Studies (Buril 2013) also suggest a relationship with $J$. nodiflora.

12. Jacquemontia gabrielii (Choisy) Buril (in Staples et al. 2015: 221).

Ipomoea gabrielii Choisy (1845). Type: French Guiana, A. Gabriel s.n. (holotype G-00227263).

Jacquemontia ciliata Sandwith (1930: 156). Type: Trinidad, in open places on the outskirts of Irois Forest, W. E. Broadway 6718 (holotype K-000613049, isotypes BM00906105, K00613050, MO-694364, S-07-4310).

High climbing perennial. Leaves ovate, shallowly cordate, shortly acuminate, thinly puberulent on veins beneath, otherwise subglabrous. Inflorescence long-pedunculate, 
(peduncle usually $>10 \mathrm{~cm}$ ), dense and often subcapitate, sepals small, \pm oblong, obtuse to rounded (acute fide Buril \& Alves 2011: 440), c. 4 mm long, glabrous but margins with a few cilia, especially at apex; corolla c. $13 \mathrm{~mm}$, usually deep blue in Bolivia. Fig. 9.

DISTRIBUTION \& HABITAT. In clearings and along the margins of moist tropical forest below $750 \mathrm{~m}$. In South America it is found in the Atlantic coastal forest of Brazil and in the Andean foothills extending from Bolivia to Colombia and then through Central America north to Nicaragua. There are scattered records from the Amazon region and it is also found in the Guyanas and on Trinidad. In Bolivia and Peru, it is mainly a plant of the eastern foothills of the Andes occurring sporadically from about $17^{\circ} 30^{\prime} \mathrm{S}$ northwards in areas with high rainfall. Map 10.

SELECTED SPECIMENS EXAMINED. BOLIVIA ( 7 seen). Cochabamba: Carrasco, near Bulo Bulo, J. R. I. Wood et al. 28902 (K, LPB, USZ); Chapare, CochabambaVilla Tunari road, Badcock 316 (K); Tiraque, near Villa Tunari, J. R. I. Wood et al. 28910 (K, LPB, USZ). La Paz: Iturralde, Rio Heath, A. Araujo-Murukami et al. 984 (LPB). PERU. (10 seen). Huánuco: Tingo Maria National Park, J. Wilson 8 (K). Loreto: Iquitos, S. McDaniel E M. Rimachi 17856 (MO); Florida, Rio Pilcomayo, G. Klug 2098 (BM, GH, LIL, S, US). Madre de Dios: Las Piedritas, Isla Rolin, L. Valenzuela Eं J. Farfán 9876 (MO, OXF); Salvación - Shintuya, A. Gentry et al. 23594 (MO). Pasco: Oxapampa, L. Hernani 299 (MO); Iscozacin, D. N. Smith Eे J. Salick 8330 (MO, OXF). San Martín: Caceres, Tocache Nuevo, T. Plowman $\mathcal{E}^{\circ} \mathrm{J}$. Schunke 7501 (K).

CONSERVATION STATUS. Least Concern. Although there are relatively few records from both Peru and Bolivia, this species is widespread in tropical rain forest and secondary scrub derived from tropical rain forest. It is almost certainly under-recorded, partly because it flowers in the dry winter season when less collecting is carried out.

PHENOLOGY. This is a winter flowering species with all records from June to September.

NOTE. Not all records of this species in databases and checklists can be trusted; most, if not all specimens from Paraguay cited as Jacquemontia ciliata in Tropicos are probably errors, R. Degen 1553, Itaipú Binacional 237, G. Marín Ẽ B. Jiménez 272 and Simonis et al. 63 are Jacquemontia velutina while Stevens 31299 is a third species.

Apart from Jacquemontia unilateralis, this species is perhaps the most attractive of those occuring in Bolivia and Peru. It can cover shrubs with a mass of blue flowers during the winter dry season. The sepals are often obscurely ciliolate so they may be interpreted as glabrous.

13. Jacquemontia gracilis Choisy (1845: 399). Type: Brazil, Pernambuco, Terra Nova, Martius s.n. (holotype M-0184732).
Slender usually decumbent herb; leaves subsessile with petioles $<5 \mathrm{~mm}$ long, oblong-elliptic, apex mucronatecuspidate, thinly pubescent. Inflorescence lax, few-flowered, usually with $1-2$ (-4) flowers; sepals subequal, lanceolate, obtuse, scarious-margined, ciliolate, sometimes also abaxially thinly pubescent, $6-7 \mathrm{~mm}$ long; corolla white, $2-2.2 \mathrm{~cm}$. Figs 10A, B, 13G.

DISTRIBUTION \& HABITAT. A plant of bushy places in cerrado. Scattered in occurence through most of the Cerrado biome in Brazil and Bolivia but never common. In Bolivia only known from three sites. Map 3.

SELECTED SPECIMENS EXAMINED. BoliviA ( 6 seen). Santa Cruz: Ñuflo de Chávez, between Guadelupe and Concepción, J. R. I. Wood et al. 28097 (LPB, OXF, USZ). Velasco, San Juan Bautista, near San Ignacio, J. R. I. Wood et al. 24798 (K, LPB, UB, USZ); P.N. Noel Kempff Mercado, Camp. Huanchaca 1, B. Mostacedo et al. 1803 (MO, USZ).

CONSERVATION STATUS. This is perhaps the only example where the threat is under-estimated by a categorisation of Vulnerable (VU) based on an extent of occurrence of 14,010.768 $\mathrm{km}^{2}$ or even Endangered (EN) based on an area of occupancy of $16,000 \mathrm{~km}^{2}$. This is a cerrado species and the cerrados are disappearing rapidly in Bolivia and elsewhere. Of its three known locations in Bolivia, it is probably extinct at one (Ñuflo de Chávez) and at another (San Juan Bautista) it is dependent on the conservation of its habtat by a private landowner's family. The third location (Huanchaca 1 in the P.N. Noel Kempff Mercado) lies in a protected area but we have no idea of its frequency and it has not been found in other parts of this national park. This species is at least Endangered (EN) in Bolivia but should current trends continue will probably be upgraded to Critically Endangered (CR). Studies should be undertaken to establish the status of this species in the P.N. Noel Kempff Mercado as a matter of urgency.

NOTES. Preliminary molecular studies (Buril 2013) suggest this species is most closely related to Jacquemontia estrellensis, rather than J. mairae, which it superficially resembles in its lax inflorescence with white flowers.

\section{Jacquemontia gracillima (Choisy) Hallier f. (1893:} 541).

Aniseia gracillima Choisy (1845: 430). Type: Brazil, Piauí, in pascuis prov. Piauhiensis et in pratis prope Terra-Nova, Martius 2458 (holotype M-0184730).

Slender, usually annual herb; stems at first erect, then decumbent to ascending; leaves shortly petiolate, glabrous, oblong or lanceolate, base cuneate to rounded, apex mucronate. Inflorescence of few-flowered axillary cymes; bracteoles small, linear; sepals unequal, outer cordate, suborbicular, rounded, becoming scarious, strongly 


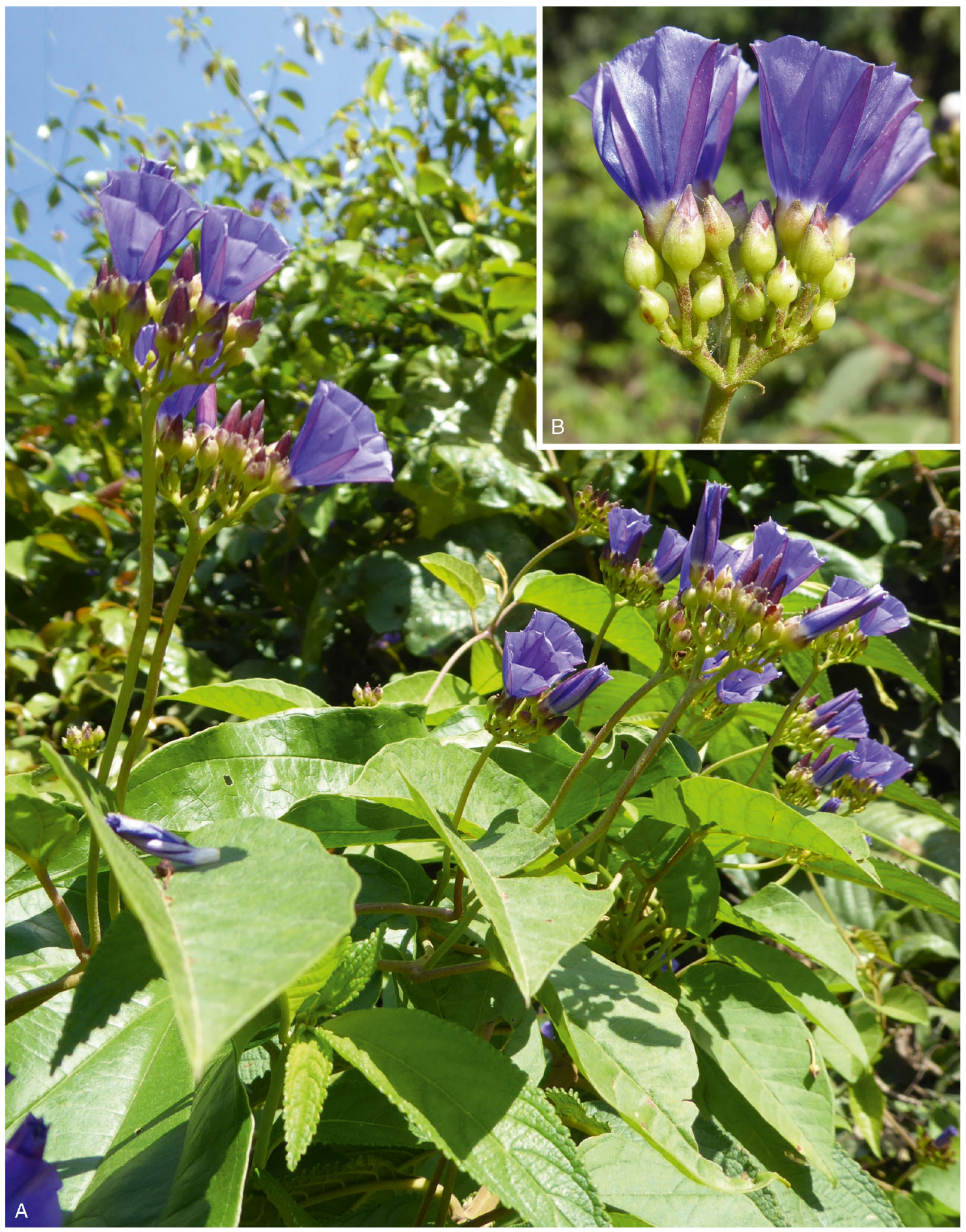

Fig. 9. Jacquemontia gabrielii. PHOTOS: MAIRA TATIANA MARTINEZ. 


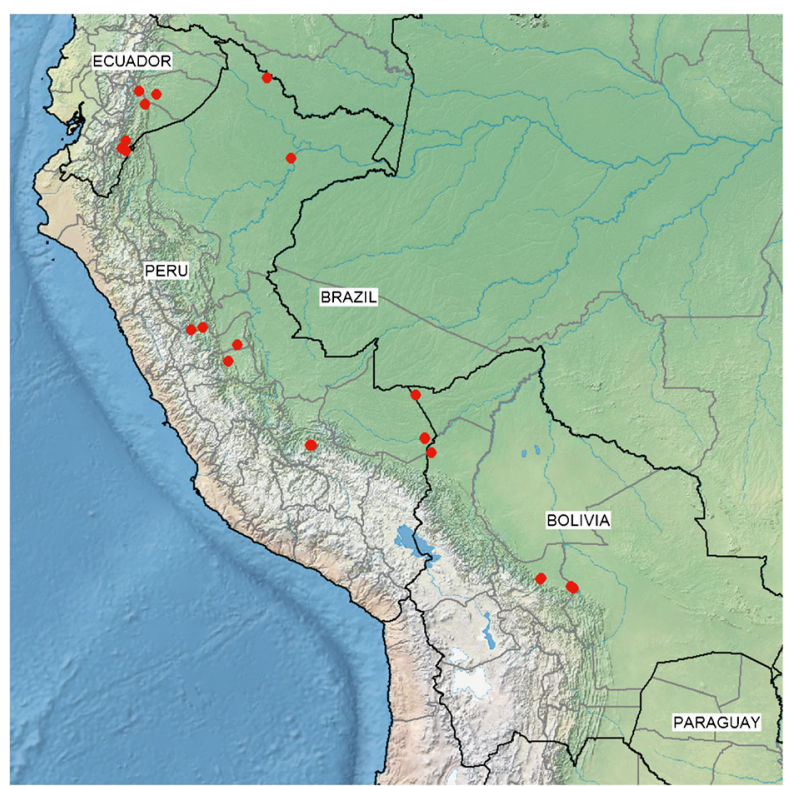

Map 10. Distribution of Jacquemontia gabrielii in Peru, Bolivia and southern Ecuador.

accrescent in fruit; corolla white with dark purple centre. Fig. 10C.

DISTRIBUTION \& HABITAT. Widely distributed through much of the Cerrado and Caatinga biomes of Brazil, from where it extends into the Chiquitania region of eastern Bolivia. It is also frequent in Venezuela and there are isolated records from Colombia and Panama. In Bolivia, it occupies two very distinct habitats in the Cerrado biome. In Nuflo de Chávez and Velasco, it grows on granite rock platforms in five locations, whereas in Chiquitos it grows on sandy roadsides in cerrado chaqueño (abayoy). The Chiquitos plants are much more robust with stems over a metre long, perhaps having been stimulated by fire in the previous winter. Map 1.

SPECIMENS EXAMINED. BOLIVIA (7 seen). Santa Cruz: Chiquitos, Taperas-San Juan, J. R. I. Wood et al. 29136 (USZ). Nuflo de Chávez, $10 \mathrm{~km} \mathrm{~N}$ of Carmen, J. R. I. Wood et al. 24240 (K, LPB, UB, USZ); El Cerrito, J. R. I. Wood et al. 27768 (K, LPB, USZ). Velasco, Cerro Pelao J. R. I. Wood E H. Huallya 20784 (HSB, K, LPB); near San Martín, J. R. I. Wood et al. 26108 (K, LPB, UB, USZ); near San Rafael, J. R. I. Wood E D. Soto 27392 (K, LPB, USZ).

CONSERVATION STATUS. This species is probably best categorised as Near Threatened (NT) in Bolivia based on an extent of occurrence of 26,950.968 $\mathrm{km}^{2}$. Although it is only known from seven locations, five rock platforms and two nearby locations in abayoy, none of these locations are especially threatened, although the smaller rock platforms might be seen as useless land suitable for fly tipping. The recently discovered locations in the abayoy are interesting as germination may have been stimulated by fire suggesting there is a bank of seed available for growth in favourable circumstances.

TYPIFICATION. Choisy cited Martius obs. n. 2458 as the type of this species. There is only a single sheet of this number in Martius' Herbarium (M-0184730) and this was annotated by Choisy so should be treated as the holotype. Austin's selection of Martius no. 19 as lectotype (Austin 1998: 418) should be rejected as this number was not cited by Choisy and is, additionally, represented by two sheets.

NOTE. Molecular studies (Buril 2013) suggest this is an isolated species in Jacquemontia. It is very distinctive because of the annual habit, large accrescent outer sepals and the white corolla with dark reddish-purple centre. The hairs are $3-6$-armed but this is often difficult to discern.

15. Jacquemontia longipedunculata J.R.I.Wood, sp. nov. Type: Bolivia. La Paz, Franz Tamayo, P.N. Madidi, Union de los Rios Tanhuara y Pelechuco, 14 44'51"S 6856'58"W, $1820 \mathrm{~m}$, A. F. Fuentes, J. Salas $\mathcal{E} R$. Huasurco 14378, (holotype LPB, isotypes MO, OXF).

http:/ /www.ipni.org/urn:lsid:ipni.org:names:77216475-1

Twining herb of unknown height but vigorous and probably reaching at least $1 \mathrm{~m}$, indumentum of simple and 2 - 3-branched hairs; stem densely pubescent. Leaves petiolate, $1.6-11 \times 0.5-5 \mathrm{~cm}$, ovate, acute and very shortly mucronate, base cordate, margin undulate, both surfaces tomentellous, minutely punctate, veins somewhat reticulate abaxially; petioles $0.6-4.5$ $\mathrm{cm}$, tomentellous. Inflorescence of dense, long-pedunculate, axillary capitula; peduncles $13-20 \mathrm{~cm}$ long, pubescent; bracts at base of capitulum, petiolate, foliose, $0.7-2.7 \times 0.6-0.8 \mathrm{~cm}$, oblong, gradually narrowed at both ends, shortly mucronate, tomentellous, persistent; bracteoles at base of flowers, $12-15 \times 1-2 \mathrm{~mm}$, oblong, slightly overtopping the capitulum so giving it a whiskery appearance; pedicels $0-2 \mathrm{~mm}$; sepals slightly unequal, outer $7-8 \times 2 \mathrm{~mm}$, narrowly ovate, acuminate, villous, inner $5-6 \times 2-2.5$ $\mathrm{mm}$, broadly oblong, glabrous except for the villous margins; corolla $10-14 \mathrm{~mm}$ long, blue, glabrous, narrowly tubular, the limb weakly spreading with the midpetaline bands terminating in a tooth; stamens included, filaments $4-5 \mathrm{~mm}$ long, anthers c. $1.75 \mathrm{~mm}$ long; style c. $7 \mathrm{~mm}$ long, stigma bilobed with $1 \mathrm{~mm}$ long elliptic lobes; ovary conical. Capsule immature, subglobose, c. $3 \times 3 \mathrm{~mm}$, glabrous. Figs $11 \mathrm{~A}-\mathrm{G}, 12 \mathrm{~A}$.

RECOGNITION. Distinguished by its long-pedunculate, bracteate capitula. Also distinctive are $12-15 \mathrm{~mm}$ long bracteoles that slightly exceed the capitulum, so 


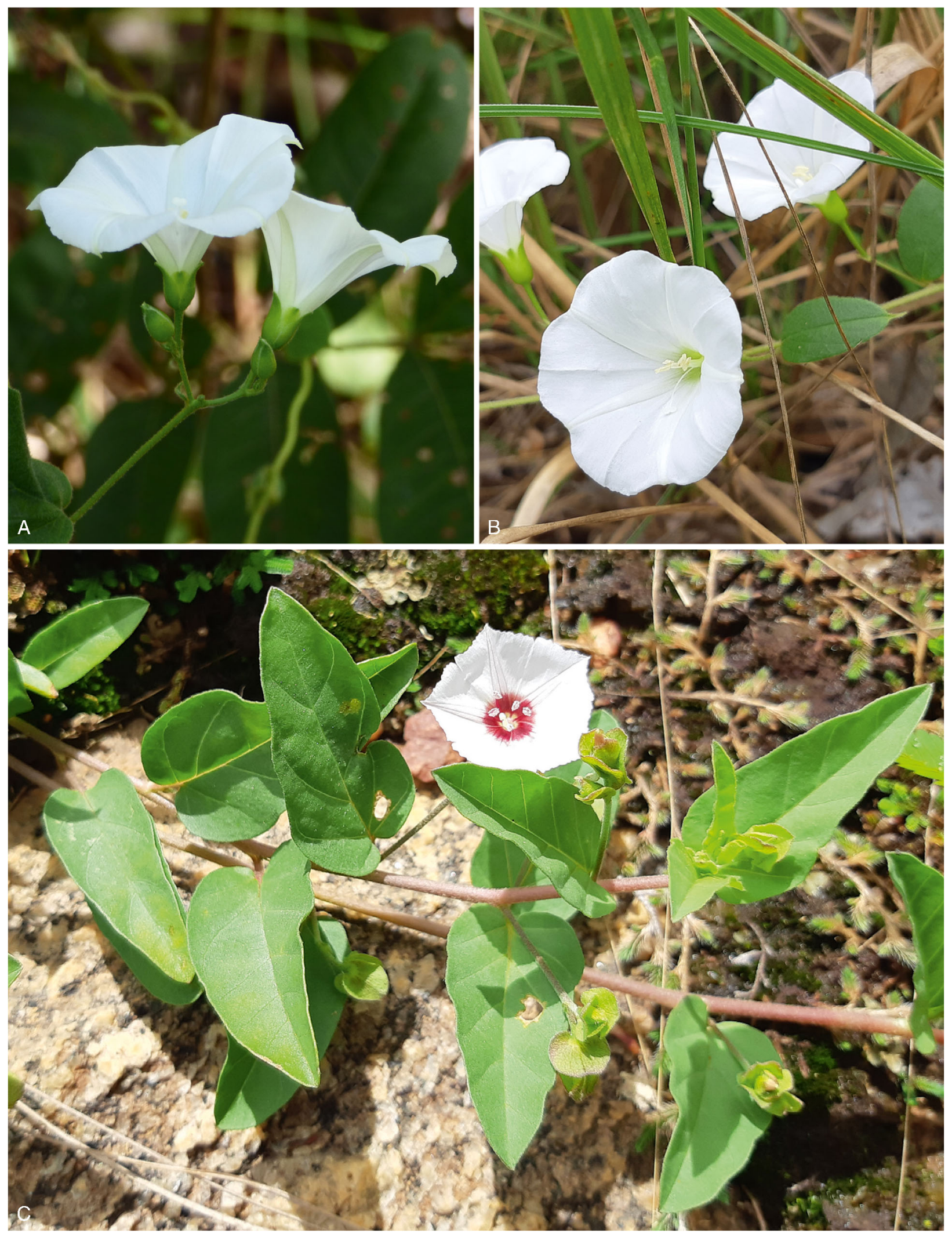

Fig. 10. A - B Jacquemontia gracilis; C J. gracillima. PhOtos: A MAIRA TATIANA MARTINEZ; B, C ROXANA LEDEZMA. 


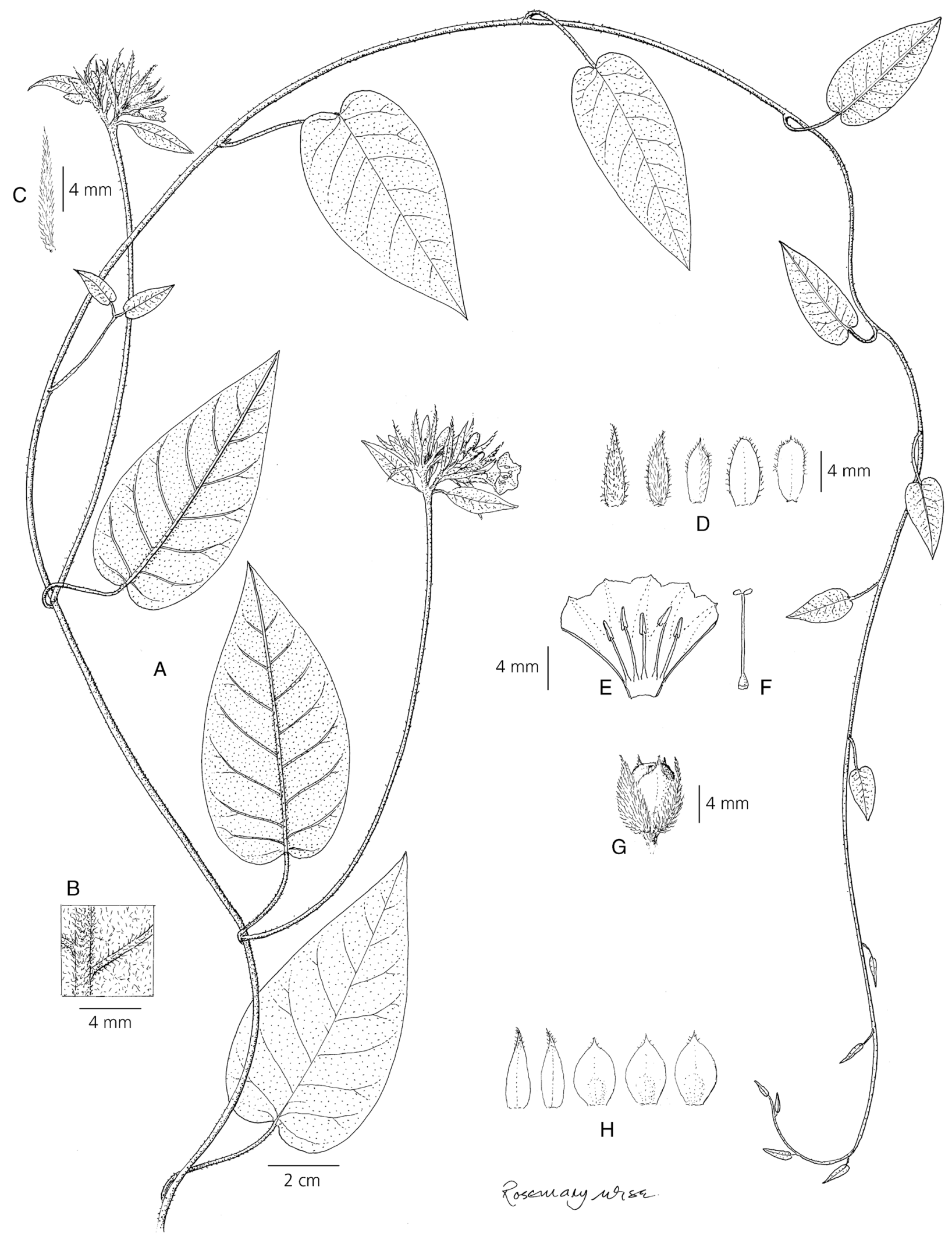

Fig. 11. Jacquemontia longipedunculata A habit; B abaxial surface of leaf; C bracteole; D sepals, outermost (left) to innermost (right); E corolla opened up to show stamens; F ovary and style; G capsule. H J. acuminata, sepals, outermost (left) to innermost (right). A - G from A. F. Fuentes et al. 14378; H from Beck 29482. DRAWN BY ROSEMARY WISE. 
giving it a whiskery appearance. The sepals are also distinctive, the outer tomentose, the inner glabrous with villous margins. Unlike other Bolivian and Peruvian species, it somewhat resembles Jacquemontia guayanensis (Aubl.) Meisn. in its inflorescence structure and indumentum but the prominent bracts and bracteoles distinguish it.

DISTRIBUTION \& HABITAT. Rocky riverine vegetation in seasonally moist hill forest at $1820 \mathrm{~m}$. Map 14 .

SPECIMENS EXAMINed. BOLIVIA. La Paz: Franz Tamayo, P.N. Madidi, Union de los Rios Tanhuara y Pelechuco, $14^{\circ} 44^{\prime} 51^{\prime \prime S} 68^{\circ} 56^{\prime} 58^{\prime \prime} \mathrm{W}, 1820 \mathrm{~m}$, A. F. Fuentes et al. 14378, (MO, OXF, LPB).

CONSERVATION STATUS. The single record would suggest that this species should be categorised as Critically Endangered (CR) but nothing is known of the population so Data Deficient would be correct (DD) at the present time. The only known location lies within the Madidi National Park so enjoys a degree of protection.

16. Jacquemontia lorentzii (Kuntze) Peter ex O'Donell (1960a: 15).

Convolvulus lorentzii Kuntze (1898: 213). Type: Argentina, Salta, Metán, Pasaje del Rio Juramento, Lorentz E Hieronymus 284 (holotype $\mathrm{B} \dagger$, photo FFOBN03763; isotypes BR000013306984, CORD00003741, F-0054951, LIL-001408, NY-00688145).

Vigorous twining herb. Leaves ovate, cordate, mucronate, puberulent. Inflorescence pedunculate, lax, puberulent; bracteoles $2-3 \mathrm{~mm}$, filiform, fugacious; sepals puberulent, ovate-rhomboid, acute to shortly acuminate, strikingly accrescent, $3-4 \times 2-3 \mathrm{~mm}$ at anthesis, accrescent to $6 \times 5 \mathrm{~mm}$ in fruit; corolla 10 $15 \mathrm{~mm}$ long, blue. Fig. 12B.

DISTRIBUTION \& HABITAT. Low to middle altitudes in the Andean foothills and inter-Andean valleys of central and southern Bolivia extending into neighbouring parts of Andean Argentina, 500 - $2300 \mathrm{~m}$ but rare above $1700 \mathrm{~m}$, often in arid scrub and dry forest relics. Map 11.

SELECTED SPECIMENS EXAMINED. BOLIVIA (32 seen). Chuquisaca: Boeto, Pampas del Tigre, J. R. I. Wood et al. 20535 (HSB, K, LPB); Calvo, Vaca Guzman, Lliully $\mathcal{E}^{\circ}$ Portal 760 (CTES, HSB); Siles, Rio Azero, J. R. I. Wood et al. 13303 (K, LPB); Tomina, El Vilar, J. R. I. Wood et al. 19526 (BOLV, HSB, K, LPB). Cochabamba: Esteban Arce, Puente Rio Caine, J. R. I. Wood et al. 19275 (BOLV, K, LPB); Campero, Buenavista, Pasorapa, C. Antezana 615 (BOLV, MO). Santa Gruz: Caballero: Est. Lanza Lanza, near Saipina, E. Gutierrez 1517 (BOLV); Cordillera, Abapó-Charagua, J. R. I. Wood Eீ F. Mamani 27485 (K, LPB, USZ); Florida, Quirasillas, J. R. I. Wood et al. 28409 (LPB, OXF, USZ); Ibañez, Quebrada Salada, M. Nee E M. A. Sundae
51980 (LPB, USZ); Vallegrande, Puente Santa Rosa, G. A. Parada et al. 2853 (MO, USZ). Tarija: Gran Chaco, serrania entre Yacuiba and Carapari, J. R. I. Wood et al. 28306 (LPB, OXF, USZ); O'Connor, Palos Blancos-Entre Rios, J. R. I. Wood et al. 28039 (LPB, OXF, USZ).

CONSERVATION STATUS. This species should be considered Least Concern (LC) based on its extent of occurrence of $76,711.489 \mathrm{~km}^{2}$. It is quite frequent in suitable habitats and not threatened by deforestation or intensive agriculture.

NOTE. Jacquemontia lorentzii has been both neglected and misunderstood. It is characterised by the ovaterhomboid, acute to shortly acuminate sepals. These are very small in immature specimens but are accrescent and quite large in fruiting examples. It has been confused with $J$. cumanensis and a few specimens are somewhat indeterminate in their sepal shape, for example Parada E Rojas 2514, but J. cumanensis is usually easily distinguished by the cordate sepals. The sepals of J. lorentzii actually resemble those of $J$. unilateralis, especially the forms found at Sorata, but the inflorescence is usually lax and somewhat diffuse unlike the subcapitate inflorescence of $J$. unilateralis. The shape of the sepals also somewhat recalls those of $J$. pentanthos but the texture and indumentum is very different from the papery sepals of that species, the bracteoles are deciduous and the inflorescence usually much laxer.

17. Jacquemontia mairae J.R.I.Wood E R.Clegg, sp. nov. Type: Bolivia, Tarija: Gran Chaco, Villamontes to Palos

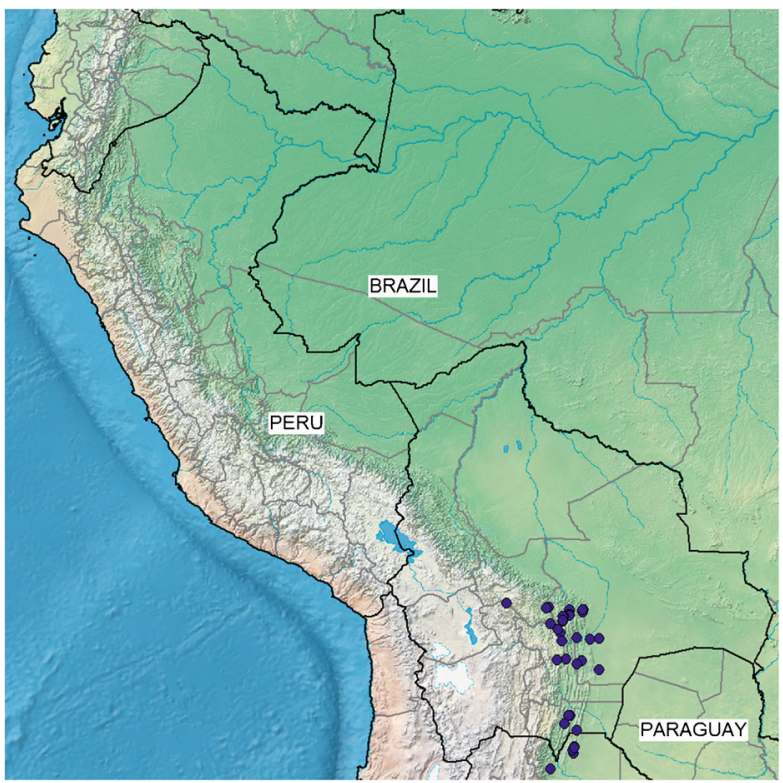

Map 11. Distribution of Jacquemontia lorentzii in Bolivia and northern Argentina. 

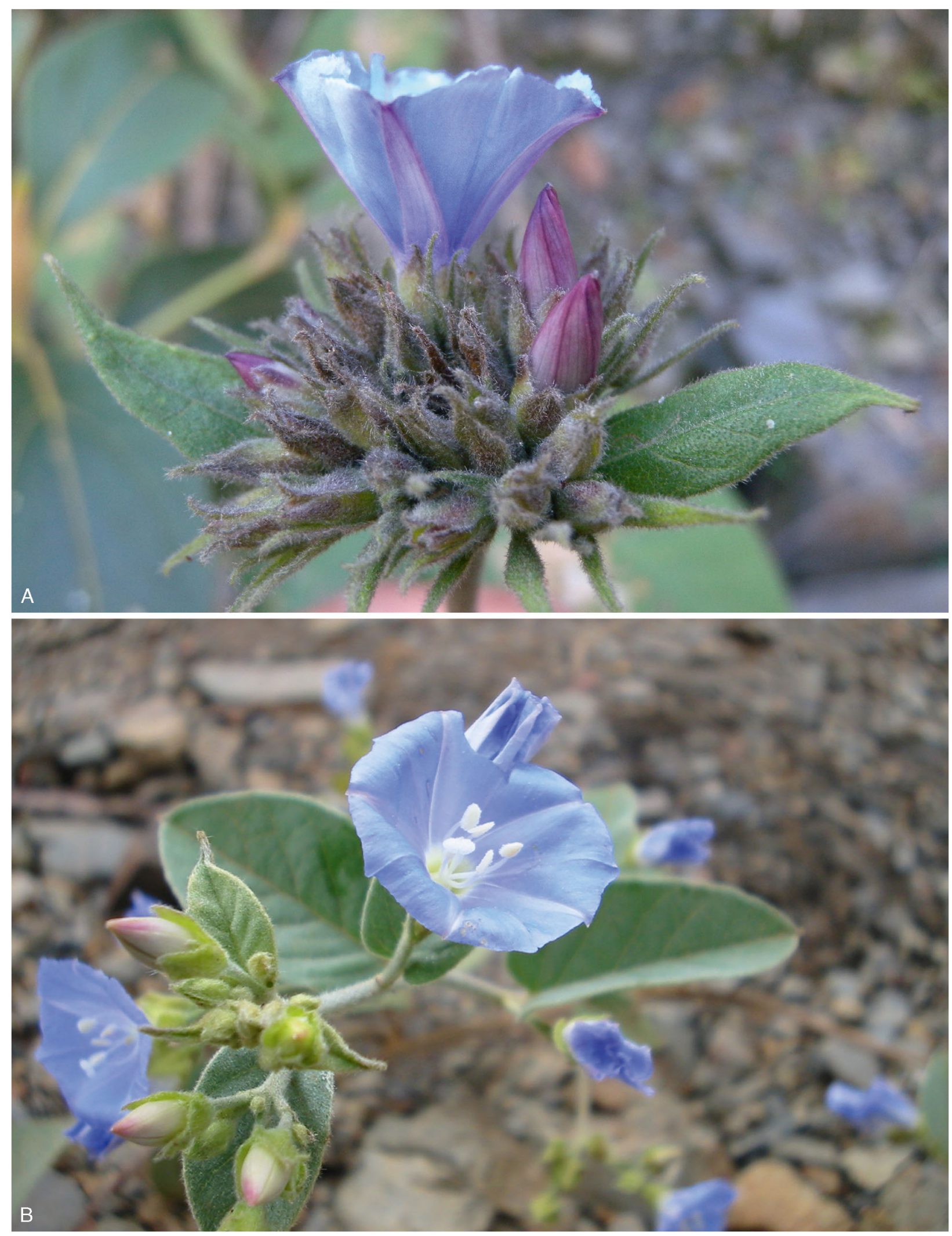

Fig. 12. A Jacquemontia longipedunculata; B J. lorentzii. PHOTOS: A ALFREDO FUENTES; B DARWIN INITIATIVE PROJECT 162/11/010. 
Blancos, 20 - $25 \mathrm{~km}$ before Palos Blancos, 21 ${ }^{\circ} 24^{\prime} 53^{\prime \prime S}$ 6339'49"W, 725 m, 24 March 2013 fl., J. R. I. Wood, D. J. N. Hind $\mathcal{E}^{\circ}$ G. Gutiérrez 28030 (holotype USZ, isotypes $\mathrm{LPB}, \mathrm{OXF})$.

http:/ /www.ipni.org/urn:lsid:ipni.org:names:77216476-1

Slender twining perennial; stems and young growth thinly pubescent but eventually glabrescent. Leaves petiolate; petioles $0.3-2.5 \mathrm{~cm}$, pubescent; lamina $1.2-5.8 \times 0.7-3.9 \mathrm{~cm}$, ovate-deltoid, base truncate, apex acute to shortly acuminate, margin entire, both surfaces subglabrous with a few scattered hairs, these sometimes 2 - 3-branched, abaxially paler, the veins with scattered hairs. Inflorescence of relatively lax, solitary, axillary pedunculate cymes with (1 -) 3 (- 12) flowers; peduncles 4.3 - $9 \mathrm{~cm}$, pubescent; bracteoles all similar, $1.5 \mathrm{~mm}$ long, linear-lanceolate, scale-like; pedicels $3-7 \mathrm{~mm}$, subglabrous; sepals slightly unequal, the inner larger than the outer, $4.5-7 \times 2.5 \mathrm{~mm}$, ovate to elliptic, mucronate, somewhat accrescent with caducous mucro in fruit, somewhat scarious but greener upwards, glabrous; corolla campanulate, somewhat flared, white, c. $2-2.3 \mathrm{~cm}$, glabrous on the exterior; filaments slightly unequal, c. $7 \mathrm{~mm}$ long, anthers $2 \mathrm{~mm}$, style weakly exserted, $12-13$ $\mathrm{mm}$, stigmas 2, broadly oblong, $2 \times 1.25 \mathrm{~mm}$. Capsule subglobose, $4-5 \mathrm{~mm}$ diam., glabrous, brown, 8-valved, 4-seeded; seeds ovoid, $2.5 \times 2 \mathrm{~mm}$, glabrous. Figs 13A - F, 14A.

RECOGNITION. In Bolivia, this species is only likely to be confused with Jacquemontia blanchetii, which grows in the same area. J. blanchetii differs in being glabrous with a blue corolla $<2 \mathrm{~cm}$ long and shorter obtuse to rounded sepals $<4 \mathrm{~mm}$ long. J. mairae has a larger white corolla, $2.2-2.5 \mathrm{~cm}$ long, shortly mucronate sepals $5.5-6 \mathrm{~mm}$ long and is puberulent on young plants, particularly the petioles, peduncles and pedicels. It also resembles the Peruvian J. elegans Helwig but the corolla is white (not blue), the sepals are glabrous and mucronate (not comose, nor rounded, obtuse). In its white flowers it has some resemblance to the cerrado species $J$. gracilis but the leaves are nearly glabrous (not pubescent), markedly petiolate with petioles up $2.1 \mathrm{~cm}$ long (not subsessile with petioles $<5 \mathrm{~mm}$ long), ovate-deltoid up to $3.5 \mathrm{~cm}$ broad (not oblong-elliptic, $<2.5 \mathrm{~cm}$ broad), the base truncate (not rounded to cuneate), the apex shortly acuminate (not mucronate), the sepals completely glabrous (not pubescent to ciliolate) and the corolla $2.2-2.5 \mathrm{~cm}$ long (not $1.5-2 \mathrm{~cm}$ long).

DISTRIBUTION \& HABITAT. Restricted to two areas of the dry Inter-Andean valley system of southern Bolivia in Tarija and Chuquisaca Departments between 700 and $1860 \mathrm{~m}$. It is a plant of dry bushland. Map 7.
SPECIMENS eXAMINED. BOLIVIA. Chuquisaca: Zudañez, ANMI El Palmar, $2 \mathrm{~km}$ antes de llegar al Cañon Willcar, siguiendo la senda Lacoyatal a Palmarcito Kasa, (UTM 03036217950399$), 1866$ m, J. Gutierrez, F. Prado, A. Paco E L. Ramos 2772 (HSB). Tarija: Gran Chaco, Villamontes to Palos Blancos, 20 - $25 \mathrm{~km}$ before Palos Blancos, $21^{\circ} 24^{\prime} 53^{\prime \prime S} 63^{\circ} 39^{\prime} 49^{\prime \prime} \mathrm{W}, 725 \mathrm{~m}$, 24 March 2013, J. R. I. Wood, D. Villarroel E B. R. M. Williams 27613 (K, LPB, USZ); ibid., 21 25'07”S 6339'55"W, 769 m, 28 Feb. 2016, J. R. I. Wood, D. J. N. Hind Ẽ G. Gutiérrez 28030 (LPB, OXF,USZ); $10 \mathrm{~km}$ SE of Palos Blancos, 21 30'305"S 634' $46^{\prime \prime} \mathrm{W}, 844$ m, 7 March 2018, J. R. I. Wood, M. T. Martinez-Ugarteche Eं G. Aramayo 28328 (LPB, OXF, USZ); 4 km E of Palos Blancos, 21 25'28"S 63 44 40"W, 785 m, 8 March 2018, J. R. I. Wood, M. T. Martinez-Ugarteche E G. Aramayo 28341 (K, LPB, OXF, USZ).

CONSERVATION STATUS. This species may be underrecorded but based on both an extent of occurrence of $3,208.621 \mathrm{~km}^{2}$ and an area of occupancy of 20,000 $\mathrm{km}^{2}$ it would be classified as Endangered (EN). However, its habitat is not in obvious danger and the main threat lies in the size of its scattered populations, which usually consist of a small number of individuals. ETYMOLOGY. This species is named for Maira Tatiana Martinez Ugarteche from the herbarium at Santa Cruz (USZ). Since 2017 Maira has been a constant companion during our fieldwork in Bolivia, has been responsible for important records of Convolvulaceae, often backed by excellent photographs and has developed a deep understanding of the family.

18. Jacquemontia nodiflora (Desr.) G.Don (1838: 283). Convolvulus nodiflorus Desr. (Desrousseaux 1792: 557). Type: Saint-Dominque [Haiti], M. Joseph Martin (holotype P-LAM, n.v., possible isotype G-00222061).

Jacquemontia confusa Meisn. (Meisner 1869: 294). Type: Brazil, Minas Gerais, "in paludosis ad Itabira prov. Minarum,” Blanchet 2879 (lectotype K-000895061, designated by McDonald (1993: 41)).

Convolvulus mucronatus Benth. (Bentham 1839: 120). Type: Ecuador, Hartweg 673 (lectotype K-000613119, designated here, isolectotypes E-00259629, G-00222059, K-000613058, LD1415338, NY-00318911, P-00608889).

Jacquemontia parviflora var. tomentosa Meisn. (Meisner 1869: 297). Type: Ecuador, Cerrito de Guayaquil, Jameson 465 (isotypes BM-001217869, BM001043708, US-00111316).

Perennial subshsrub; stems wiry and somewhat woody, much twining, pubescent when young, purplish-brown when old. Leaves small, up to $2.5(-4.5) \times 2 \mathrm{~cm}$, ovate, subcordate, shortly mucronate, shortly petiolate, paler and pubescent beneath. Inflorescence sessile or nearly 


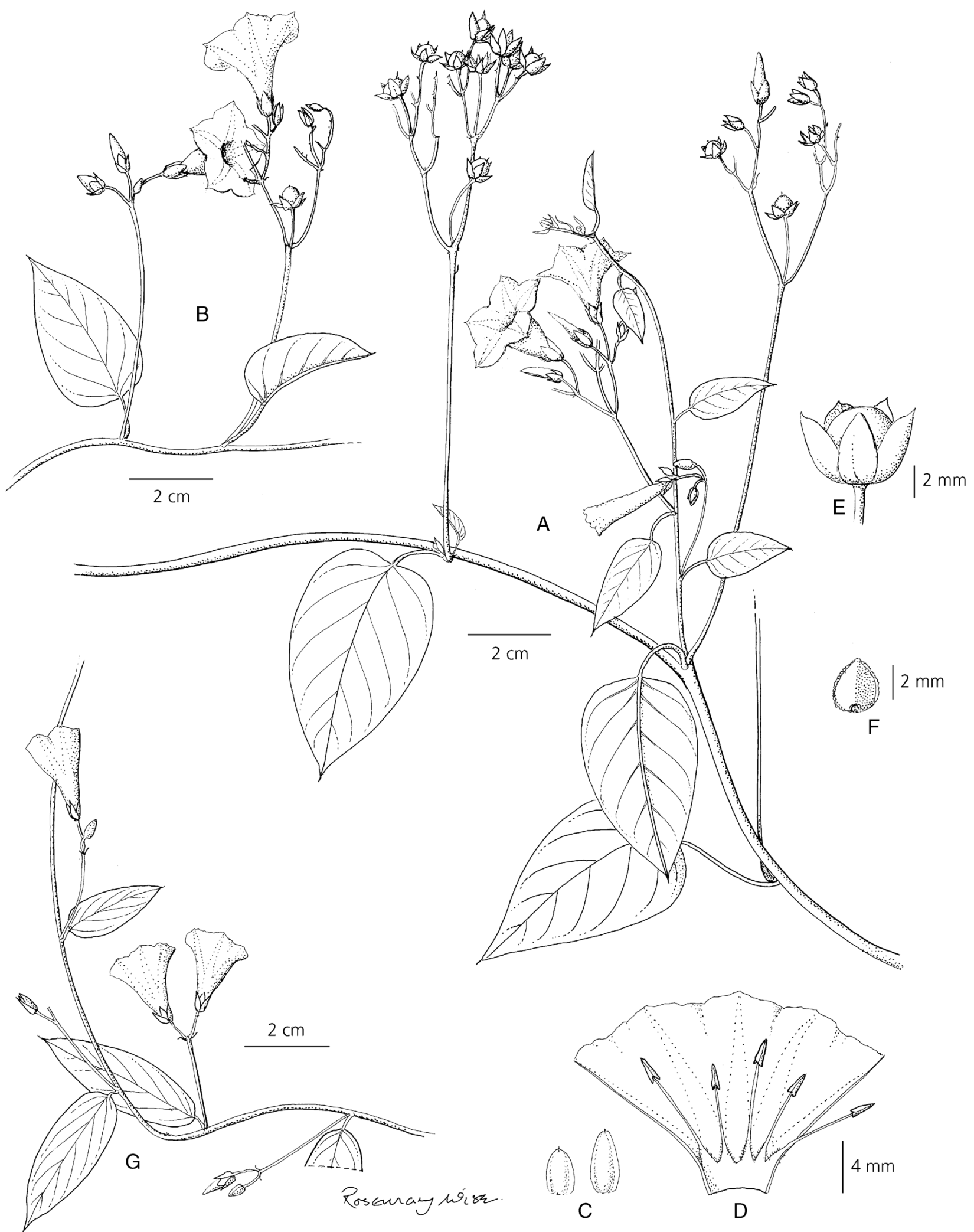

Fig. 13. Jacquemontia mairae. A habit; B portion of inflorescence; C sepals, outer (left), inner (right); D corolla opened up to show stamens; E capsule; F seed. G J. gracilis, habit. A - F from Wood et al. 28030; G from Wood et al. 28097. DRAWN BY ROSEMARY WISE. 

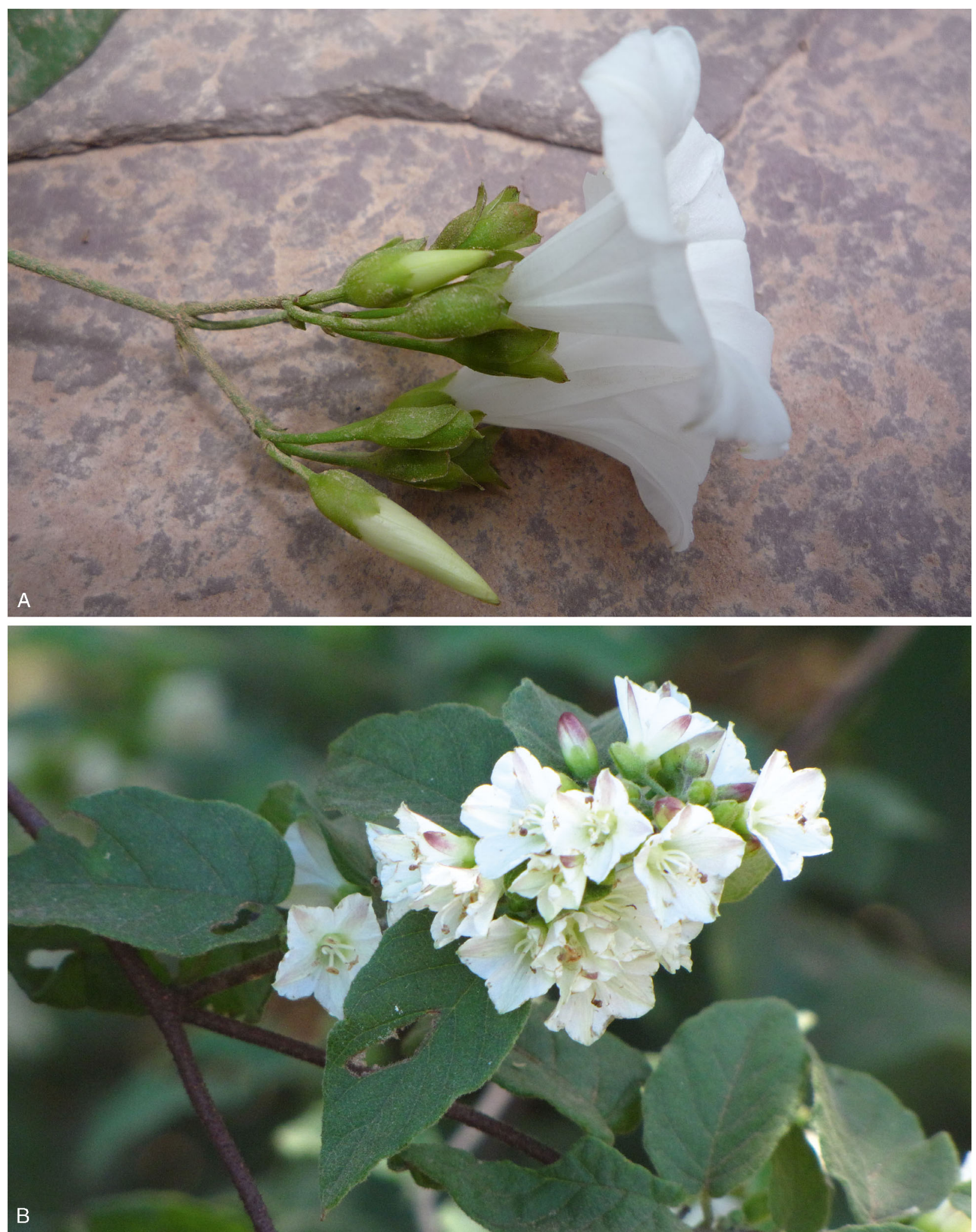

Fig. 14. A Jacquemontia mairae; B J. nodiflora. PHOtOS: A BETH WILLIAMS; B DANIEL SOTO. 
so; sepals c. $2 \mathrm{~mm}$ long and wide, rounded, pubescent; corolla white, c. $0.8-1.2 \mathrm{~cm}$ long, the midpetaline bands often dull lilac. Fig. 14B.

DISTRIBUTION \& HABITAT. A plant of dry bushland at altitudes below $600 \mathrm{~m}$, most common in Central America and the Caribbean (absent from Cuba) and in South America in four areas: the dry Caribbean coastal region of Venezuela and Colombia, the Caatinga region of NE Brazil, NW Peru and adjacent parts of Ecuador; the Chiquitania of Bolivia. Map 12. SELECTED SPECIMENS EXAMINED. BOLIVIA ( 5 seen). Santa Cruz: Chiquitos, San José-Quimome, J. R. I. Wood Eं F. Mamani 13494 (K, LPB, USZ); Velasco, San Rafael to San Miguel, J. R. I. Wood E D. Soto (K, LPB, USZ), J. R. I. Wood et al. 28669 (K, LPB, USZ); Germán Busch, Rincón del Tigre - La Gaiba, J. R. I. Wood et al. 28728 (K, LPB, USZ). PERU (4 seen). Piura: Ayabaca, Frias, A. Weberbauer 6429 (GH). Huancabamba: $R$. Ferreyra 10796 (MO). Tumbes: Centralmirante Villar, C. Diáz Ẽ E. Peña Cruz 4049 (MO); Cerros de Amotope, A. Gentry Ẽ C. Diáz 58191 (MO).

CONSERVATION STATUS. In Bolivia this species should be categorised as Vulnerable (VU) based on its extent of occurrence of $19,340.376 \mathrm{~km}^{2}$. Populations are scattered and consist of few individuals. However, its occurrence as a component of secondary scrub suggests it faces no immediate threat, although the habitat is being degraded and there is a risk that it might be cleared to create rough pasture. In Peru this species should be categorised as Endangered (EN) based on both its extent of occurrence of $1,229.177$ $\mathrm{km}^{2}$ and area of occupancy of $16,000 \mathrm{~km}^{2}$ but this will

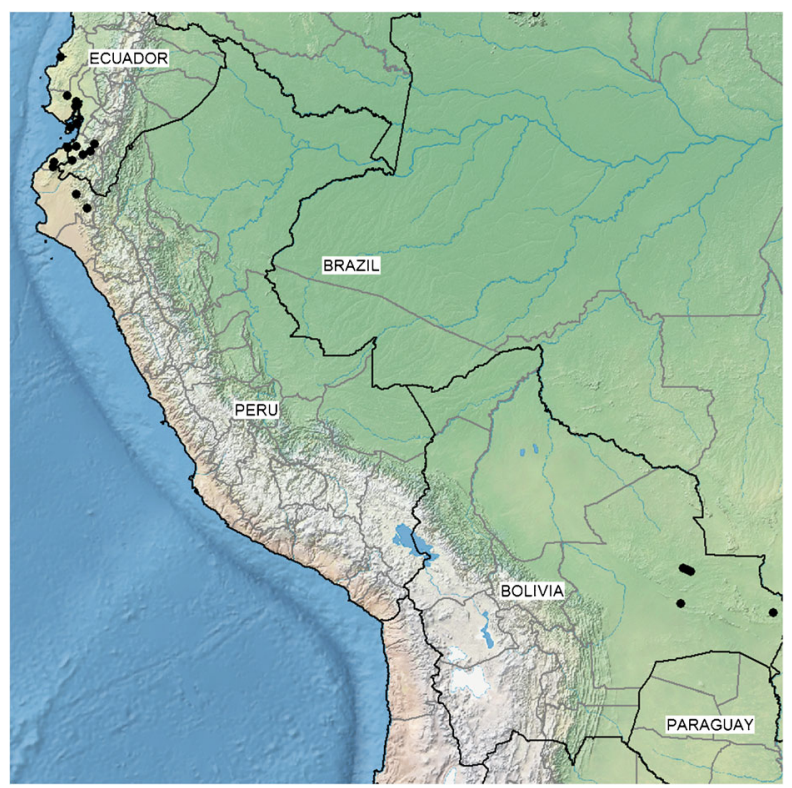

Map 12. Distribution of Jacquemontia nodiflora in Peru, southern Ecuador and Bolivia. need to be revised after populations have been carefully studied.

PHENOLOGY. This is a winter flowering species collected in Bolivia from April to July and in Peru from June to August.

NOTES. Jacquemontia nodiflora has until recently been treated as Convolvulus nodiflorus, for example, in Flora Mesoamerica (Robertson \& Austin 2012). However, molecular studies (Carine et al. 2004; Namoff et al. 2007; Buril 2013) show clearly that this species does not belong to Convolvulus but is correctly placed in Jacquemontia.

Jacquemontia confusa is sometimes treated as distinct from J. nodiflora but we cannot see any morphological reason to treat these as separate species and follow Brazilian authors (Buril 2013; Moreira et al. 2018) in recognising $J$. nodiflora only, even though we have not noted any previous formal synonymisation of the two species.

Molecular studies (Buril 2013) suggest Jacquemontia nodiflora is most closely related to J. floribunda and so presumably to $J$. chuquisacensis as well. All three species have a preference for very arid habitats and have woody stems.

We have not seen the holotype of Convolvulus nodiflorus but assume that the collection at Geneva (labelled Martin 366) is an isotype, although we are not certain it is duplicate of the plant in the Lamarck Herbarium at $\mathrm{P}$.

No lectotype has been chosen for Jacquemontia parviflora var. tomentosa as none of the specimens seen were annotated by Meisner. However, BM-001217869 is the best of the available collections and all were distributed from BM.

\section{Jacquemontia pentanthos (Jacq.) G.Don (1838:} 283).

Convolvulus pentanthos Jacq. (Jacquin 1791: 210). Type: Jacquin s.n. (lectotype W-0050655, designated by D'Arcy 1970: 559).

Convolvulus azureus Desr. (Desrousseaux 1792: 554). Type: L'amérique méridionale, Richard s.n. (holotype P-03896003).

Jacquemontia azurea (Desr.) Choisy ex G.Don (1838: 283).

Jacquemontia azurea var. alba Seeman (1854: 172). Type: City of Panama, Seeman 487 (lectotype K-000613124, designated here).

Jacquemontia violacea var. densiflora Meisn. (Meisner 1869: 296). Type: Brazil, Minas Gerais, Lagoa Santa, "ad sepes et sylvarum margines, Warming (lectotype BR-00005792610, designated here).

Jacquemontia densiflora (Meisn.) Hallier f. (1893: 543).

Jacquemontia densiflora Rusby (1899: 151), nom. illeg., non (Meisn.) Hallier (1893). Type: Bolivia, Guanai, Rusby 1845 (lectotype NY-00319294, designated 
here, isolectotypes MICH-1111330, MIN-100289, NY-00319293, NY-00319295, US-00111303, US$00111304)$.

Jacquemontia rusbyana Standl. (Standley 1936: 172). Type: Based on Jacquemontia densiflora Rusby

Twining plant. Leaves ovate, cordate, acute, shortly mucronate, subglabrous or puberulent. Inflorescences shortly pedunculate (shorter than leaves), rather dense, pubescent or (in Bolivia) glabrous; bracteoles small, linear, oblong-lanceolate to lanceolate, persistent, somewhat chartaceous, obscurely veined; sepals somewhat papery, unequal, outer ovate to ovateelliptic, acute to acuminate, $3-4 \mathrm{~mm}$, (accrescent to $6 \mathrm{~mm}$ ), inner obovate with scarious margins; corolla small $7-12(-20) \mathrm{mm}$. Fig. 15A.

TYPIFICATION. The lectotype of Jacquemontia violacea var. densiflora is the specimen from Martius' herbarium confirmed by O'Donell and held in the Brussels herbarium.

Rusby cited his own collection (Rusby 1845) and an unlocalised collection by Bang (No. 2849) after the description of Jacquemontia densiflora Rusby but the latter should be excluded as a type, as Rusby considered it a "more tomentellate form" of the new species. There are three sheets of Rusby 1845 at NY all annotated as "type col" but we have selected the sheet labelled holotype by E. K. Schofield (NY-00319294) as lectotype to avoid ambiguity.

DISTRIBUTION \& HABITAT. As here defined, widespread in tropical America growing on forest margins and in bushy places below about $1300 \mathrm{~m}$ but avoiding dry areas so absent from all of western Peru and most of the inter-Andean valleys and the Chiquitania in Bolivia. In Peru and Bolivia it is essentially a species of the eastern slopes of the Andes extending occasionally into the Amazonian lowlands. We have only seen a single record from Ecuador (A. P. Yañez et al. 1274 (QCA) from P.N. Machalilla in Manabí but Austin 1982a: 78 also cites Eggers 14505 (L, US) from Guayas. The relatively few records suggest it is very sporadic in occurrence everywhere. Map 13.

SELECTED SPECIMENS EXAMINED. BOLIVIA (24 seen). Beni: Moxos, A. Parada et al. 1562 (MO, USZ). Chuquisaca: Hernan Siles, J. Villalobos 1501 (HSB, MO). La Paz: Muñecas, A. Fuentes et al. 7131 (BOLV, LPB, MO, USZ); Sud Yungas, S. G. Beck 9276 (LPB); Tamayo, A. Araujo-Murukami et al. 2893 (LPB, USZ). Pando: Madre de Dios, boca del Río Manupare (Sena), J. Solomon 17052 (LPB). Santa Cruz: Cordillera, Bañados de Izazog, G. Navarro E I. Vargas 369 (BOLV, USZ). Guarayos, M. T. Martinez-Ugarteche 85 (K, USZ); Ibañez, J. R. I. Wood 17125 (K, LPB, USZ); Ichilo, J. R. I. Wood et al. 28290 (LPB, OXF, USZ); Velasco, L. Sánchez 141 (MO, USZ). PERU (17 seen). Cusco: Convención, H. Huamantupa 4513 (MO, OXF). Junín:
La Merced, E. P. Killip Eं A. C. Smith 23492 (US). Madre de Dios: Tambopata, P. Nuñez 9646 (MO). San Martín: Tarapoto, F. Woytkowski 35123 (LIL); near Juanjui, G. Klug 4334 (BM, S, US).

CONSERVATION STATUS. Least Concern (LC), although this might require revision in the case of Peru, as it clearly diminishes in frequency northwards with only two records from Ecuador (Austin 1982a).

NOTES. Jacquemontia pentanthos is very variable in floral dimensions and in inflorescence indumentum. The inflorescence (including bracteoles and sepals) appears always to be glabrous in Bolivia and usually so in Peru, but is sometimes pubescent elsewhere. Plants from Bolivia, Peru and Brazil have smaller corollas and shorter sepals than plants from Central America. They were previously treated as a distinct species J. densiflora. The two forms are usually easily distinguished and J. densiflora may merit recognition at subspecific rank.

Very characteristic of this species are the papery rhomboid sepals which differ in texture from those of all the other species occurring in Peru and Bolivia.

20. Jacquemontia peruviana Helwig (1927: 1138). Type: Peru, Cajamarca, Prov. Cutervo, left side of Marañon Valley at Pion, 1300 - 1400 m, June 1915, A. Weberbauer 7193 (holotype $\mathrm{B} \uparrow$, photo of holotype F-FOBN013768). Jacquemontia caudata Helwig (1927: 1137), synon. nov. Type: Peru, Cajamarca, Prov. Cutervo, Valley of Rio Llaucan, 1600 m, June 1915, A. Weberbauer s.n. (holotype $\mathrm{B} \uparrow$, photo of holotype F-FOBN013753)

A twining perennial with thin woody stems. Leaves ovate or oblong-ovate, relatively small ( $5 \mathrm{~cm}$ long), brownishtomentose, the base shallowly cordate, and the apex rounded and mucronate. Inflorescence very compact; peduncles elongate; sepals $9-10(-14) \mathrm{mm}$ in length, somewhat unequal, tomentose, ovate-acuminate terminating in a distinct aristate point; corolla blue, 17 $20 \mathrm{~mm}$ long. The seeds have a distinctive winged margin. Fig. 16.

DISTRIBUTION \& HABITAT. In Peru, known only from the two old collections cited above but quite frequent in southern Ecuador, where it grows in very dry scrub between 1300 and $1700 \mathrm{~m}$. Map 14. We have seen 10 collections from Ecuador including the following: eCUAdOR. Azuay: Pasaje - Girón, G. Harling $\mathcal{E} L$. Andersson 18727 (QCA). Loja: Bosque Malacatos, P. M. Barba et al. BOP268 (QCA); Chiguango, R. Espinosa 1217 (CTES, FCQ); Cantón Catamayo, U. Placencia $\mathcal{E}$ V. Rodríguez 195 (LOJA); La Toma - El Tambo area, J. E. Madsen et al. 7436 (AAU, LOJA); 7766 (AAU, LOJA); 7791 (AAU, LOJA).

CONSERVATION STATUS. There has been no record from Peru for more than a century so it is possibly Extinct (EX) in that country. There are, however, 

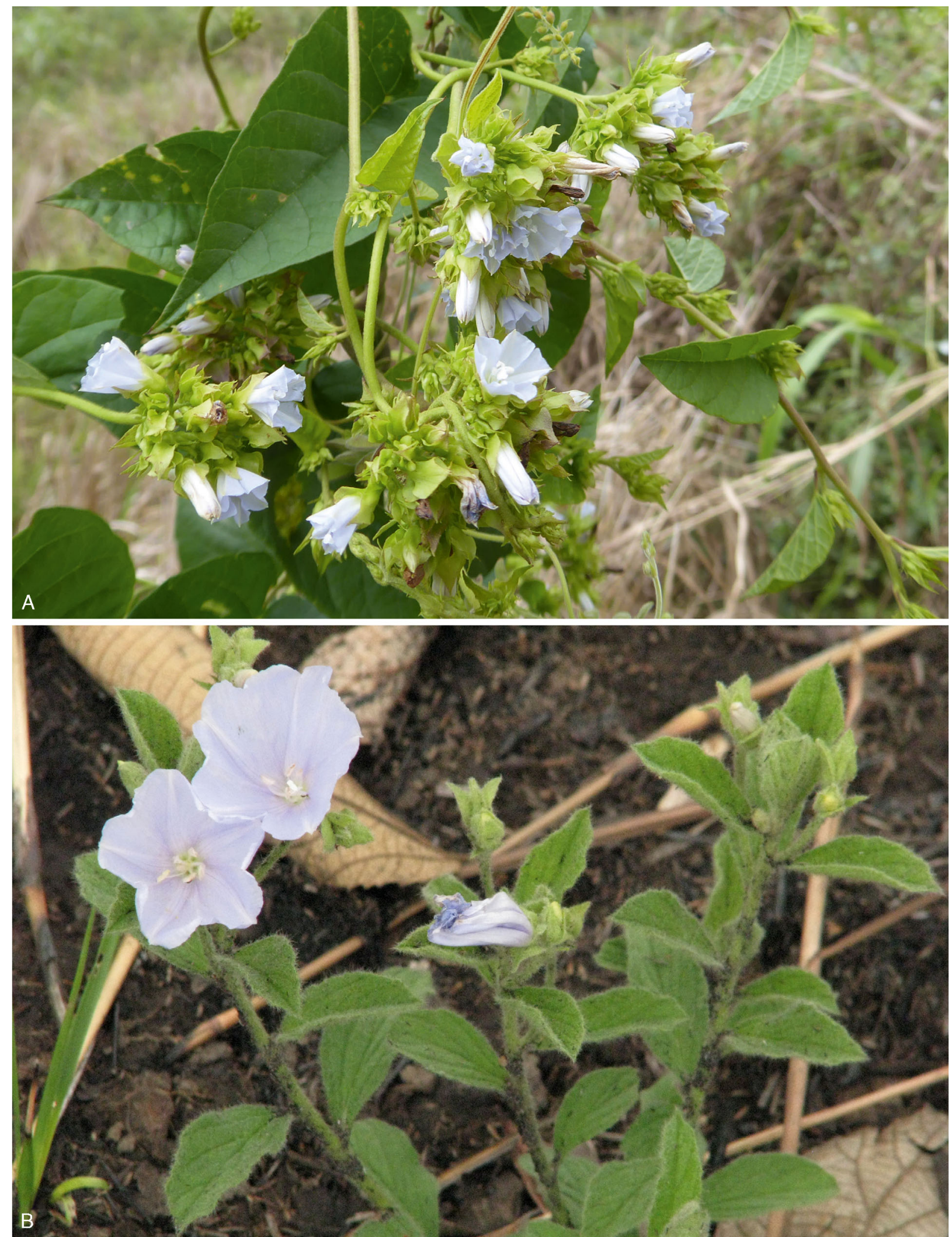

Fig. 15. A Jacquemontia pentanthos; B J. selloi. Photos: A MAIRA TATIANA MARTINEZ; B DARWIN INITIATIVE PROJECT 16-004. 


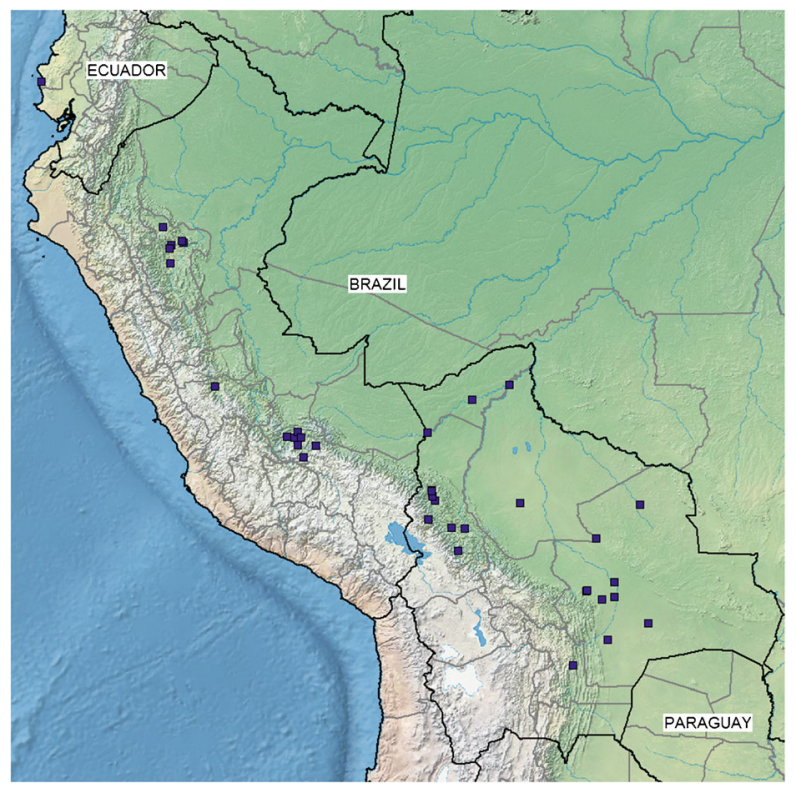

Map 13. Distribution of Jacquemontia pentanthos in Peru and Bolivia.

several, apparently healthy populations in southern Ecuador.

NOTE. There are no extant specimens of Jacquemontia caudata but this is here united with J. peruviana based on the photographs of the Berlin types at $\mathrm{F}$, the protologue and the sketches of the two calyces associated with the type collections. Both species come from Cutervo Province in Cajamarca at similar altitudes (1300 - 1600 $\mathrm{m})$, are similar in their indumentum and $17-20 \mathrm{~mm}$ long, blue corolla, differing in the sepal length $(10 \mathrm{~mm}$ long in J. peruviana but $14 \mathrm{~mm}$ in J. caudata) and the long terminal mucro on the leaf in J. caudata. Given the absence of distinguishing features except the calyx dimensions and the geographical proximity of the two collections, they are best treated as a single species. It should be noted that the specimens cited from Ecuador all conform more closely to the type of $J$. peruviana than to that of J. caudata.

Jacquemontia peruviana appears to be related to $J$. weberbaueri having the same mucronate leaf tips and similar indumentum, but differs in the much longer aristate sepals.

21. Jacquemontia selloi (Meisn.) Hallier f. (1893: 543). Ipomoea selloi Meisn. (Meisner 1869: 271). Type: Southern Brazil, Sello s.n. (B十, photo FFOBN013771).

Ipomoea selloi var. rufescens Meisn. (Meisner 1869: 271).

Type: Brazil, "ad Uberaba", Minas Gerais, Regnell 197 (lectotype, BR-0005306084 designated here).

Jacquemontia selloi var. rufescens (Meisn.) Hallier f. (1899b: 44).
A cerrado perennial with xylopodium and several ascending stems, the plant all roughly hirsute. Leaves subsessile, obovate, oblong-elliptic or elliptic; inflorescence pedunculate, few-flowered, arising from the upper leaf axils; bracteoles linear; sepals ovate, rounded to cuneate, membranous, pubescent; corolla 1.5 $2.5 \mathrm{~cm}$, blue or white. Fig. 15B.

DISTRIBUTION \& HABITAT. Eastern Bolivia, eastern Paraguay, NE Argentina and adjacent parts of the Cerrado biome in Brazil. This is a typical plant of seasonally burnt cerrado grassland at altitudes below $750 \mathrm{~m}$, emerging from a xylopodium after the first spring rains. Initial flowering takes place when shoots may be less than $10 \mathrm{~cm}$ high but these are accrescent to $50 \mathrm{~cm}$ later in the season. Of the 11 records seen from Bolivia, six are from the Concepción area and three from Santiago de Chiquitos, assuming this is where D'Orbigny 939 (BR0005306411) was collected. Map 8.

SELECTED SPECIMENS EXAMINED. BOLIVIA (11 seen). Santa Cruz: Chiquitos, Santiago de Chiquitos, J. R. I. Wood et al. 23708 (K, LPB, UB, USZ). Nuflo de Chávez: W of San Javier, J. R. I. Wood 15152 (K, LPB), Concepción, T. Killeen 2185 (LPB, USZ), El Carmen, S of Concepción, R. Guillen et al. 2807 (USZ). Velasco, N of Santa Rosa de La Roca, J. R. I. Wood et al. 23644 (K, LPB, USZ, UB).

CONSERVATION STATUS. This is a cerrado species and the cerrados are disappearing rapidly in all areas where Jacquemontia selloi is recorded from Bolivia; the location where it grew near Santa Rosa de la Roca, for example, was ploughed up in 2010 and several near Concepción have also been destroyed by creeping urbanisation. Unfortunately, it is not reported from the less threatened cerrados of the hill-top mesetas. A categorisation of Endangered (EN) based on an area of occupancy of $36,000 \mathrm{~km}^{2}$ would seem more appropriate than Near Threatened (NT) based on its extent of occurrence.

PHENOLOGY. This is a spring-flowering species appearing after burning with the onset of the first rains so mostly found in flower in October and November.

22. Jacquemontia sphaerocephala Meisn. (Meisner 1869: 309). Type: Brazil, Minas Gerais, Paracatu, Riedel s.n. (lectotype NY-00336557, designated here).

Ipomoea cephalantha Dammer (1897: 39), nom. illeg., non Baker (1894). Type: Brazil, Glaziou 19670 (holotype B十, isotypes K, P-03879091, P-03879092, R00012334).

Jacquemontia cephalantha Hallier f. (1899a: 30). Type: Based on Ipomoea cephalantha Dammer

Jacquemontia hallieriana Ooststr. (Ooststroom 1936: 216). Type based on Ipomoea cephalantha Dammer 


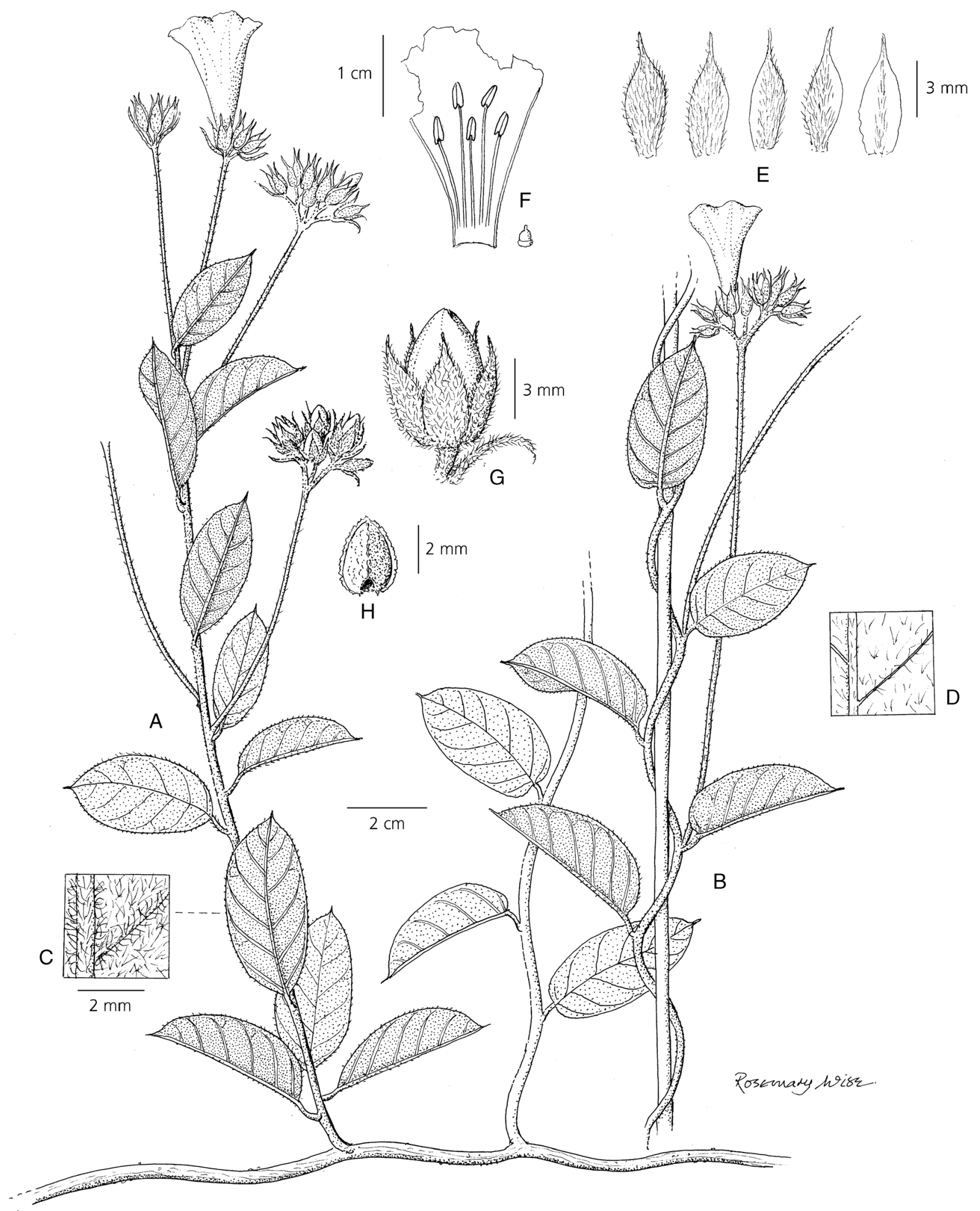

Fig. 16. Jacquemontia peruviana. A habit; $B$ habit (twining); C abaxial surface of leaf; $D$ adaxial surface of leaf; $E$ sepals, outermost (left) to innermost (right); F corolla opened up to show stamens; G fruiting inflorescence; H seed. A, C, E - G from Madsen 7760; B, D from Madsen 7436. DRAWN BY ROSEMARY WISE. 


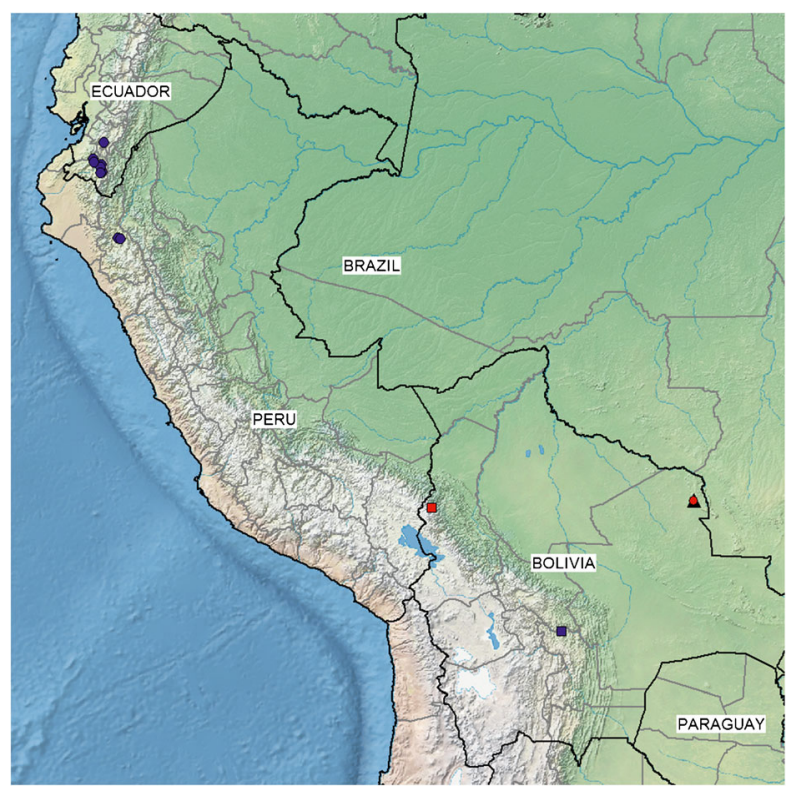

Map 14. Distribution of Jacquemontia peruviana (•) in Peru

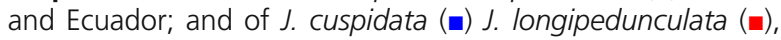
J. sphaerocephala (•) and J. villosissima ( $\mathbf{\Delta})$ in Bolivia.

Erect herb from perennial woody base to c. $40 \mathrm{~cm}$, all vegetative parts tomentose; inflorescence terminal on main stem, subcapitate; peduncles and pedicels absent; sepals unequal, the outer ovate-subrhomboid, 13 $\times 6 \mathrm{~mm}$, broadly apiculate or caudate, the inner linearlanceolate $11-12 \times 1-2 \mathrm{~mm}$, acuminate; corolla pale blue, c. $1.5 \mathrm{~cm}$ long.

DISTRIBUTION \& HABITAT. A typical species of open grassy cerrado appearing after fire. Widely distributed in the Cerrado biome of central Brazil but never very common. In Bolivia it is known from two collections from the same area on the meseta of the Noel Kempff National Park at 650 m. Map 14.

SPECIMENS EXAMINED. BoliviA. Santa Cruz: Velasco, P.N. Noel Kempff Mercado, Camp. Huanchaca 2, S. Jiménez Ẽ E. Gutiérrez 1315 (LPB, USZ), ibid. J. R. I. Wood et al. 18210 (K, LPB, USZ).

CONSERVATION STATUS. This species should be treated as Critically Endangered (CR) as it is only known from two collections from the same site. Even though the collection locality is in a protected area, the absence of other collections suggests it is very rare and it could be threatened by any modification to its habitat.

23. Jacquemontia sphaerostigma (Cav.) Rusby (1899: 151).

Convolvulus sphaerostigma Cav. (Cavanilles 1799: 54).

Type: Mexico: "Habitat in Mindanao, floret Decembri; et in diversorio vulgo del Alto Camaron Regni mexicani ubi floret April et Maio. Vidi siccum in eodem herbario." Nee s.n. (holotype MA222550, isotype fragment F-0054761F).

Jacquemontia hirsuta Choisy (1838: 41), nom. illeg., superfl. Based on Convolvulus sphaerostigma Cav.

Jacquemontia viscidulosa Hoehne (1922: 51). Type: Brazil, Mato Grosso do Sul, [Corumbá], Porto Esperança, Kuhlmann 1272 (lectotype R000027509, designated by Buril \& Staples 2018, isolectotype SP000697).

Jacquemontia agricola Rusby (1927: 337). Type: Bolivia, Canamina, 15.VII.1922, H. H. Rusby 80 (holotype NY00319276).

Conspicuously twining, rather slender herb. Leaves usually very small, < $3 \mathrm{~cm}$ long, ovate, deltoid, mucronate; glandular trichomes present on vegetative parts, especially on young stems. Inflorescence moderately dense with up to 25 flowers; bracteoles linear-filiform, $2-3 \mathrm{~mm}$ long, persistent; sepals $5-6(-7) \mathrm{mm}$, linear, acute, erect, pilose with long multicellular glandular hairs; corolla small, $8-10 \mathrm{~mm}$, blue. Fig. 17 .

DISTRIBUTION \& HABITAT. Widely distributed through tropical America from southern Mexico south to the extreme NE of Argentina and central Bolivia but rare or absent from the Caribbean islands and parts of continental South America including Ecuador and much of Colombia and Peru. It is a plant of disturbed grassy and bushy places usually at low altitudes but occurring exceptionally above 1000 in Peru and Bolivia. Map 15.

SELECTED SPECIMENS EXAMINED. BOLIVIA (22 seen). Beni: Ballivian, Reyes, J. R. I. Wood E D D. Wasshausen 13848 (K, LPB); Yacuma, Est. Biológica del Beni, J. Balderrama 582 (LPB, OXF). Cochabamba: Campero, Peña Colorado, J. R. I. Wood Eं H. Huaylla 20273 (HSB, K, LPB, USZ). La Paz: Larecaja: Guanai, H. $H$. Rusby 1844 (BM, K); Sud Yungas J. Solomon E M. Nee 14312 (LPB); Tamayo: P.N. Madidi, A. Fuentes et al. 5613 (LPB, USZ). Santa Cruz: Chiquitos: Santiago de Chiquitos, J. R. I. Wood et al. 24652 (K, LPB, UB, USZ); Germán Busch: Rincón del Tigre, J. R. I. Wood et al. 24547 (K, LPB, UB, USZ); Ichilo, Buenavista, J. R. I. Wood E D. Soto 27958 (K, LPB, USZ); Sara, Rio Jorge, J. R. I. Wood et al. 18317 (K, LPB, USZ); Vallegrande: Com. Plan Sitanos, L. Arroyo et al. 6701 (MO, USZ); Velasco: San Miguel, J. R. I. Wood et al. 28180 (LPB, OXF, USZ). PERU (13 seen). Amazonas: Chachapoyas, A. Mathews 2051 (BM, K). Cajamarca: Jaén, Santa Rosa, Cerro San Cristóbal, E. Ortiz et al. 1280 (MO, OXF). Cusco: La Convención, Echarate, A. Weberbauer 7950 (BM, GH, K, US); ibid., L. Valenzuela et al. 6708 (MO, USM); Macchu Pichu, L. Valenzuela et al. 1909 (MO, OXF). San Martín: Tarapoto, R. Spruce s.n. (BM, GH, $\mathrm{K}, \mathrm{OXF}$ ). 

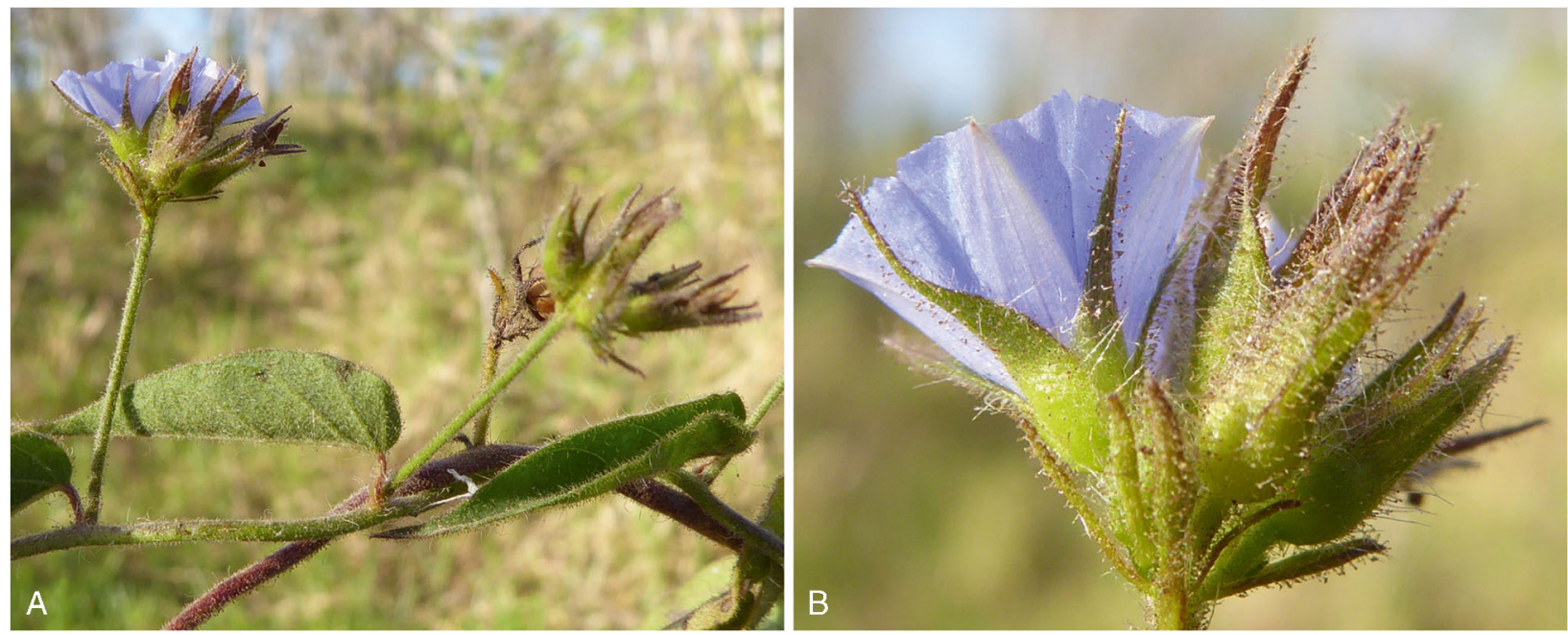

Fig. 17. A - B Jacquemontia sphaerostigma. PHOTOS: MAIRA TATIANA MARTINEZ.

CONSERVATION STATUS. Least Concern, although clearly less common in Peru and apparently absent from Ecuador (Austin 1982a).

NOTE. Readily recognised by the long multicellular hairs that cover all vegetative parts. This indumentum suggests a relationship with Jacquemontia evolvuloides, something confirmed by molecular studies (Buril 2013). However, it is readily distinguished from that species by the dense, somewhat umbelliform inflorescence.

\section{Jacquemontia tamnifolia (L.) Griseb. (Grisebach} 1862: 474).

Ipomoea tamnifolia L. (Linnaeus 1753: 162). Type:

[United States], Volubilis Car. Tamni folio subhirsuto" in Dillenius, Hort. Eltham. 2: 428, t. 318, f. 410 (Dillenius 1732), lectotype, designated by Verdcourt, Fl. Trop. E. Afr., Convolvulaceae 35 (1963).

Convolvulus tamnifolius (L.) G.Mey. (Meyer 1818: 95). Convolvulus praelongus S.Moore (1895: 403). Type: Brazil, Mato Grosso, S. Moore 1101a (holotype BM000953198).

Jacquemontia rondonii Hoehne (1922: 53). Type: Brazil, Mato Grosso, Serra da Paca Nova, M. C. Rondon 2263 (holotype SP, isotype R00027490).

High twining herb to $5 \mathrm{~m}$; stems, pilose with long spreading, superficially simple hairs, which often become brownish when dry. Leaves petiolate, ovatedeltoid, acute, subcordate, margins ciliate. Inflorescence of long-pedunculate, axillary, bracteate capitula; bracteoles foliose, shortly petiolate, lanceolate to ovateelliptic, shortly acuminate, pilose, equalling or slightly exceeding the capitulum; sepals subequal, lanceolateacuminate, $8-12 \times 1-1.5 \mathrm{~mm}$, densely pilose adaxially with long hairs; corolla pale blue, c. 9 $15 \mathrm{~mm}$ long. Fig. 18A, B.

DISTRIBUTION \& HABITAT. Bushy scrub and dry forest often surrounding pools or seasonally flooded areas at low altitudes below about $500 \mathrm{~m}$. Pantropical in distribution but scattered and generally uncommon in South America with only three confirmed records from Peru and 14 from Bolivia, four from one location, the Pampas de Toledo. Map 16.

SELECTED SPECIMENS EXAMINED. BOLIVIA (14 seen). Beni: Cercado, Rio Tijamuchi, M. R. Orellana 832 (LPB); Itenez, Baures, R. Scolnik E R. Luti 673 (K, SI). La Paz: Ituralde, al E de las Sabanas del Heath,

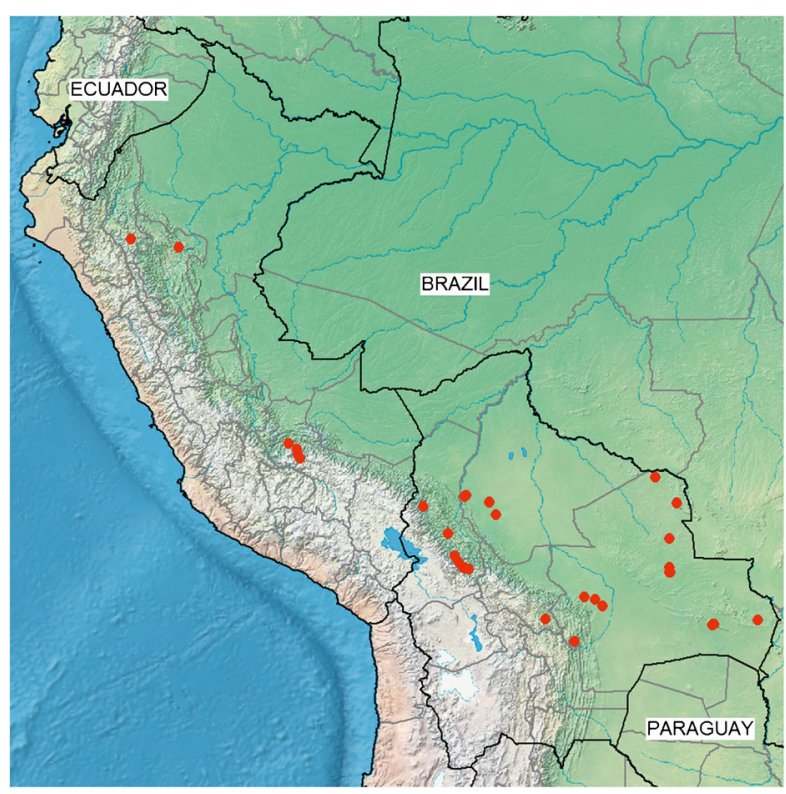

Map 15. Distribution of Jacquemontia sphaerostigma in Peru and Bolivia. 

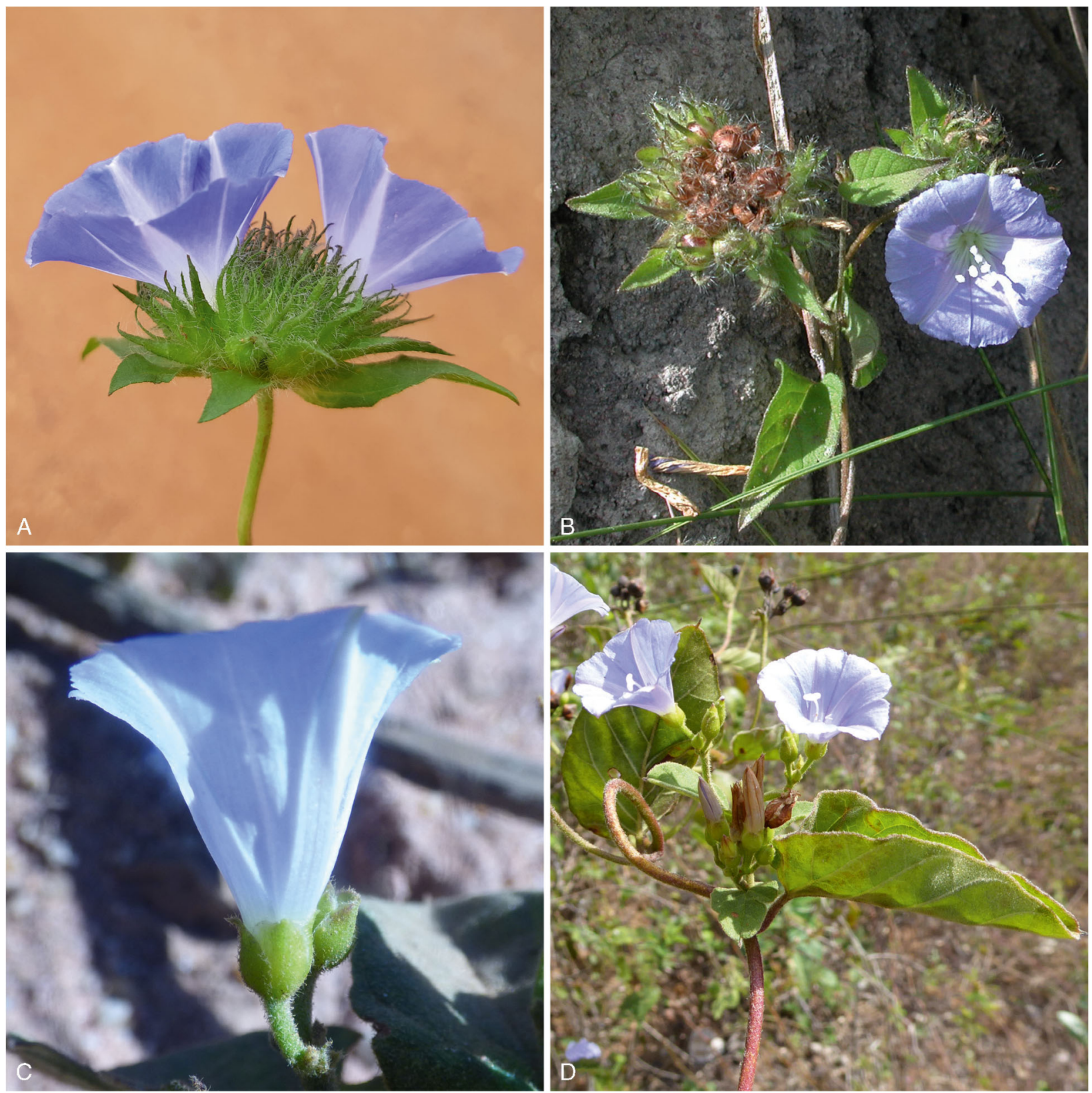

Fig. 18. A - B Jacquemontia tamnifolia; C - D Jacquemontia velutina. PHOTOS: A ROXANA LEDEZMA; B LOUISE EMMONS; C ROSEMARY CLEGG; D MAIRA TATIANA MARTINEZ.

N. Paniagua 834 (LPB). Santa Cruz: Chiquitos, San José, J. R. I. Wood et al. 22886 (K, LPB); Taperas, J. R. I. Wood et al. 29142 (USZ). Velasco, Flor de Oro, M. Nee 41547 (NY, USZ); Pampas de Toledo, R. Guillen 3710 (BOLV, LPB, USZ); near San Martín, J. R. I. Wood $\mathcal{E}^{\circ}$ D. Soto 27917 (OXF, USZ); near San Miguel de Velasco, J. R. I. Wood et al. 29049 (USZ). PERU (3 seen). Loreto: Balsapuerto, G. Klug 3065 (BM, K, MO). San Martín: Tarapoto-Yurimaguas, M. Rimachi 5217 (MO). CONSERVATION STATUS. Based on on its extent of occurrence, this species should be treated as Least Concern (LC) in Bolivia. However, with only three records from two sites in Peru, Endangered (EN) might seem appropriate for that country. We feel that this latter categorisation might be premature given the sudden appearance of this species in considerable quantity after fire in 2019, suggesting there exist marked fluctuations in population sizes. It may be that seed remains dormant for many years so Least Concen (LC) is probably the most accurate categorisation pending further studies of its populations and life history.

NOTE. This species often occurs singly or, at least in very small populations. However, in 2019, after 


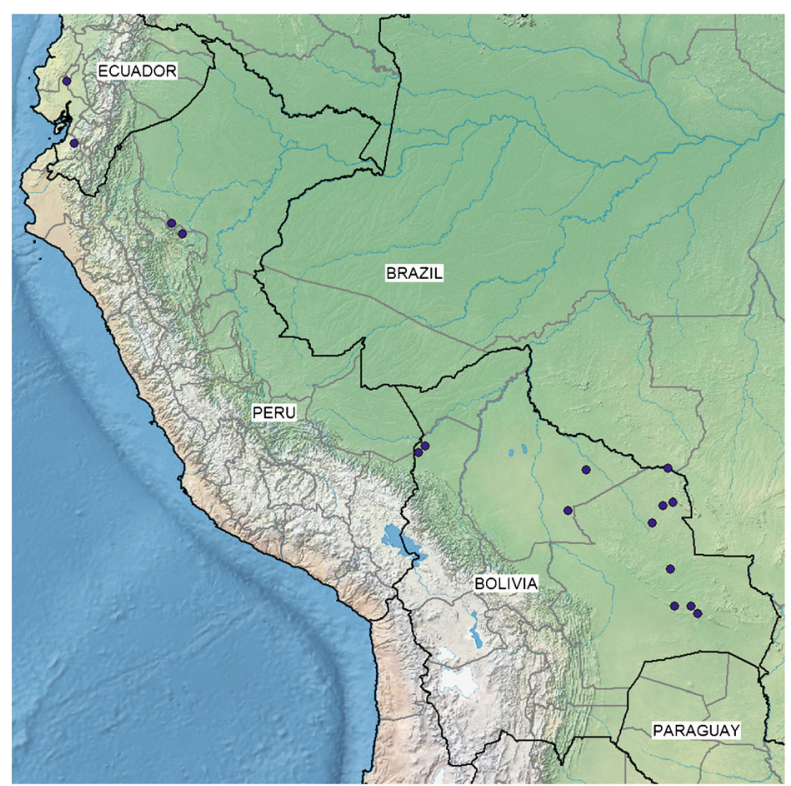

Map 16. Distribution of Jacquemontia tamnifolia in Peru and Bolivia.

extensive fire in areas of dry forest near San Miguel, it was the most abundant creeper climbing over dead trees over a considerable area, suggesting that seeds may remain dormant until propitious circumstances, such as fire or ash, encourage germination.

\section{Jacquemontia unilateralis (Roem. \& Schult.)} O'Donell (1950: 470).

Convolvulus secundus Ruiz \& Pav. (Ruiz \& Pavon 1799: 10), nom. illeg., non C. secundus Desr. (Desrousseaux 1792). Type: Peru, "in Lurincircuitu ad Pachacamac tractum" (lectotype MA-814701, designated by Buril \& Staples (2018).

Convolvulus unilateralis Roem. \& Schult. (Roemer \& Schultes 1819: 284). Type: Based on Convolvulus secundus Ruiz \& Pav.

Jacquemontia secunda Choisy (1838: 62). Type: Based on Convolvulus secundus Ruiz \& Pav.

Jacquemontia prominens Helwig (1927: 1138). Type: Peru, Piura, below Tias, on way to Chulucanas, May 1912, A. Weberbauer 6431 (holotype $\mathrm{B} \dagger$, isotypes $\mathrm{F}-0042384 \mathrm{~F}$, G-00222056, GH-0054641, US-00111322).

Herb with woody base. Leaves ovate-suborbicular, shallowly cordate, subrounded and abruptly acute, thinly hirsute to tomentose, the hairs conspicuously branched, usually shortly petiolate, the petioles $\mathrm{c} .1 \mathrm{~cm}$ long (rarely to $3 \mathrm{~cm}$ ). Inflorescence of pedunculate, compact cymes, exceeding the leaves and often subcapitate in form; bracteoles filiform, relatively persistent; sepals unequal, outer, ovate-elliptic to subrhomboid, puberulent to tomentellous, (5-) 6 $8 \times 4-5 \mathrm{~mm}$, acute to shortly mucronate, not strongly accrescent; inner sepals smaller; corolla $15-25 \mathrm{~mm}$ long, deep blue. Fig. 19.

DISTRIBUTION \& HABITAT. Widespread and apparently common in the coastal region of Peru north to the extreme south of Ecuador, growing both on coastal lomas and on drier west facing mountains up to at least $2400 \mathrm{~m}$. In Bolivia only known from three collections from the Sorata area around $2500 \mathrm{~m}$. We have not seen specimens from Brazil and Brazilian records (Flora de Brasil en construccion 2020) require confirmation. The few images available online show a plant with more narrowly ovate sepals than is typical of Peruvian Jacquemontia unilateralis. Map 5.

SELECTED SPECIMENS EXAMINED. BOLIVIA (3 seen). La Paz: Larecaja, Sorata, Mandon 1488 (K, BM), J. R. I. Wood 11805 (K, LPB). PERU (53 seen). Ancash: Casna, E. Cerrate et al. 5160 (MO). Arequipa: Caraveli, O. Whalley et al. 1841 (K). Cajamarca: San Miguel, S. Llatas Quiroz 859 (MO, OXF), Contumaza, I. Sanchez Vega et al. 3043 (F, MO). Ica: Lomas de Amara, O. Whalley et al. 1720 (K). La Libertad: railhead above Pacasmayo, H. O. Forbes s.n. (BM). Lambayeque: Rio Motupe, A. Sagastegui 11459 (MO, OXF), PortachueloOlmos, S. Llatas Quiroz 3151 (F). Lima: Huarachiri, T. H. Goodspeed E₹ H. E. Stork 11486 (GH, K), Chancay, R. Ferreyra 19184 (MO), Ate, Puruchuco, A. Mathews 521 (K, OXF). Piura: Sullana, C. Diáz E S. Baldeon 2375 (F, MO), Paita, O. Haught 37 (GH, US). Tacna: H. H. Rusby 2007 (K). Tumbes: Casitas to Cañaveral, A. Gentry Ẽ C. Diáz 58188 (F, MO), Zorritos, A. Weberbauer 7748 (F, LIL).

CONSERVATION STATUS. In western Peru, this species is very common and is clearly of Least Concern (LC). In Bolivia, in contrast, it is only known from around the town of Sorata. There are no obvious threats to the Bolivian population but given its very restricted extent of occurrence and area of occupancy in Bolivia, and with a total population of probably less than a thousand individuals a categorisation of Vulnerable (VU) under the IUCN criterion D would seem appropriate.

NOTES. Buril \& Staples (2018: 3) consider Jacquemontia secunda Choisy to be the valid name for this species, but this cannot be correct, as the replacement name Convovulus unilateralis was made by Roemer \& Schultes almost twenty years earlier with a clear reference to Convolvulus secundus Ruiz \& Pav.

This is probably the most attractive Jacquemontia species with its striking deep blue flowers but has been subject to different interpretations over the years. As understood here it is a variable species. Helwig (1927: 1138) separated J. prominens on the basis of its larger leaves with longer petioles and tomentose sepals while O'Donell (1960b: 85) maintained J. prominens on the basis of the 3-branched rather than 4-branched hairs of J. unilateralis. With a much larger range of 

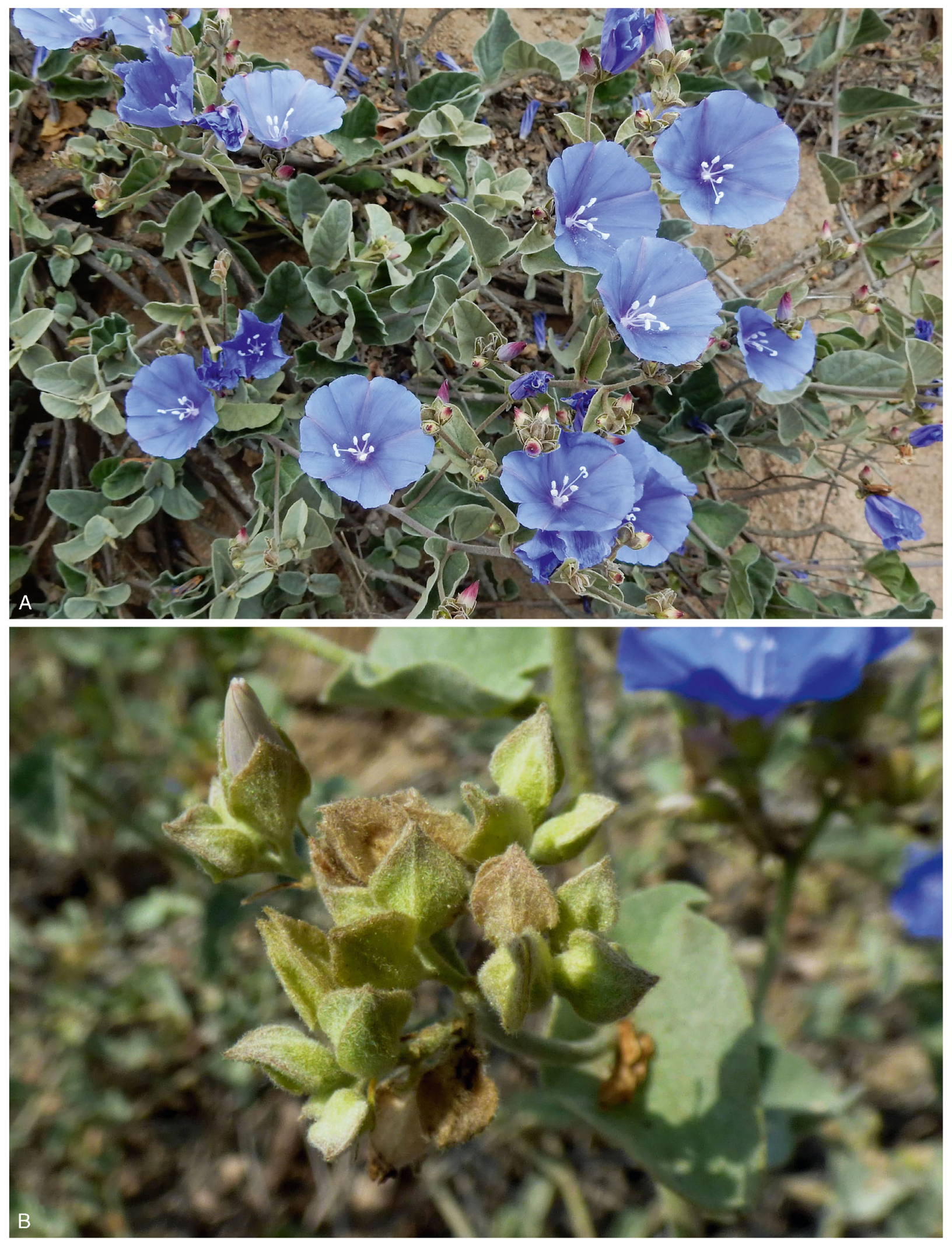

Fig. 19. Jacquemontia unilateralis. PHOTOS: OLIVER WHALLEY. 

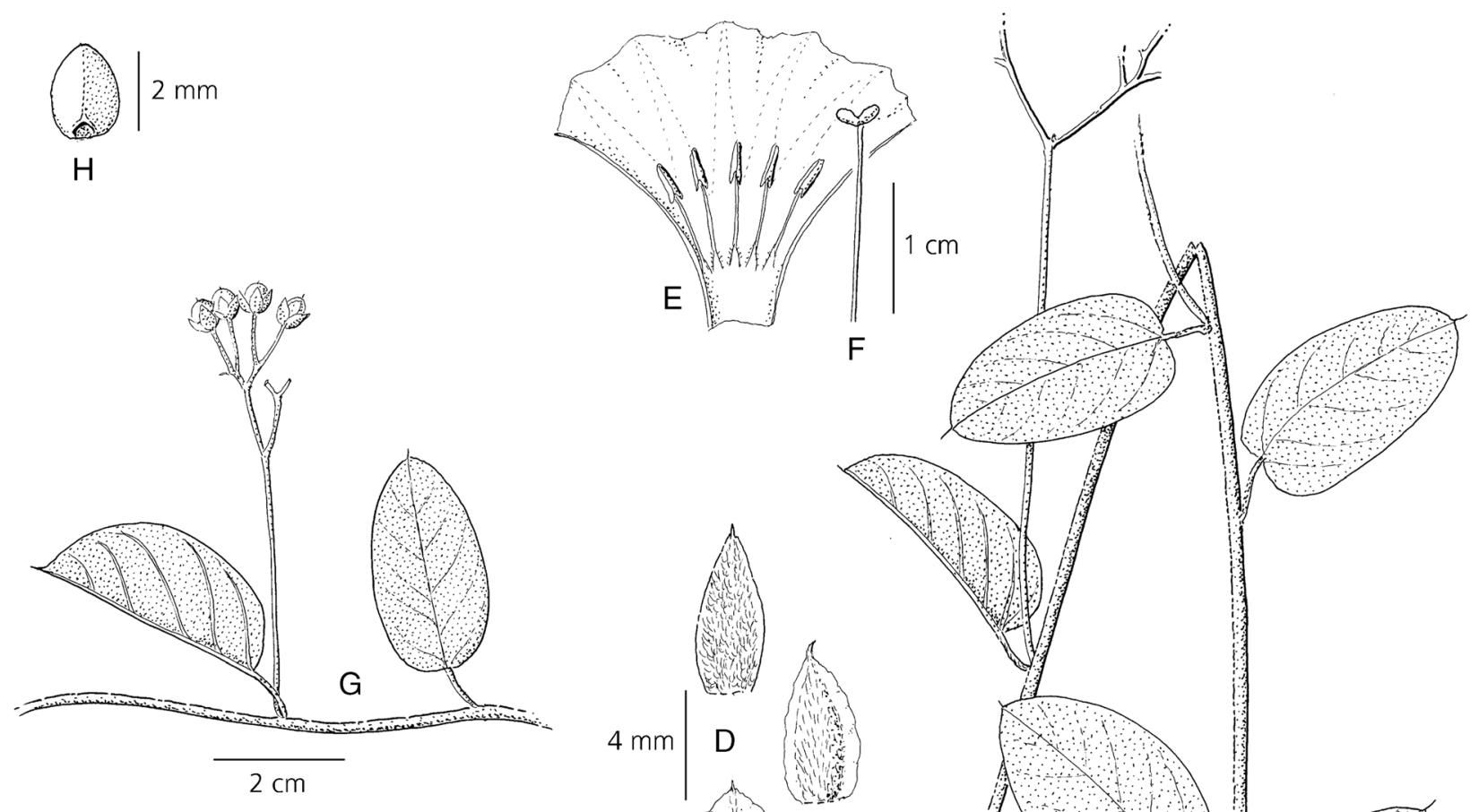

B
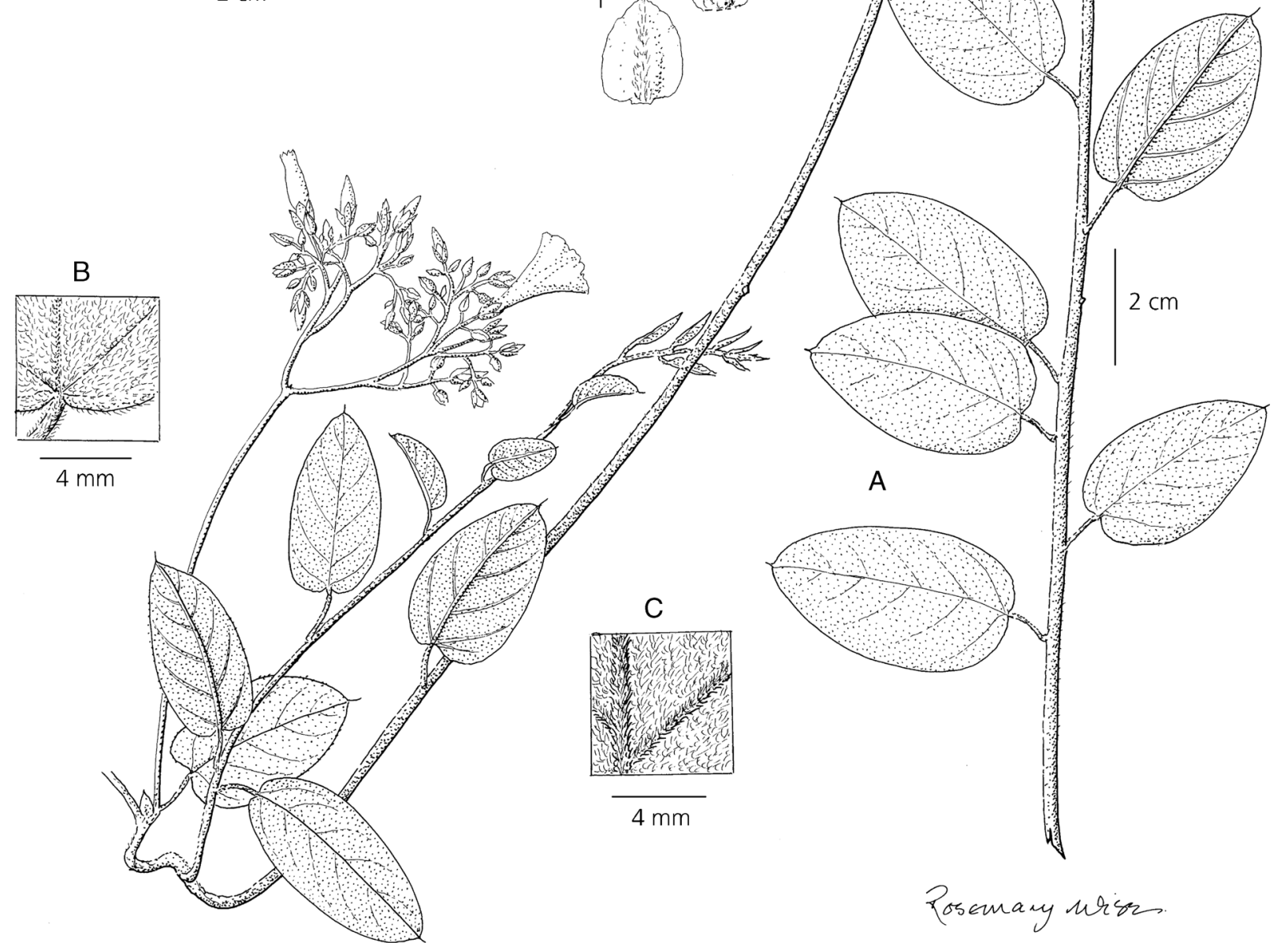

Fig. 20. Jacquemontia weberbaueri A habit; B adaxial surface of leaf; C abaxial surface of leaf; D sepals, outer (upper), middle (middle right), inner (lower); E corolla opened up to show stamens; F style; G fruiting inflorescence; H seed. A - C from Campos \& Diaz 2188; D - H from Diaz 10693. DRAWN BY ROSEMARY WISE. 
specimens available, none of these differences holds up, so we agree with Macbride (1959) that J. prominens should be united with J. unilateralis. Austin (1982a) went further uniting $J$. prominens with $J$. corymbulos a but the sepals of the two species are very different although a few specimens collected where their ranges overlap might be considered intermediate such as S. Llatas Quiroz 3151 (F) from Portuchuelo de Olmos, Lambayeque, Peru or C. Sandeman 34 (OXF) from Salinas in Ecuador. At the other end of the range of J. unilateralis, the three collections from the Sorata region of Bolivia have smaller sepals $(4-5 \times 3 \mathrm{~mm})$ and a smaller corolla, only $13-17 \mathrm{~mm}$ in length. These specimens thus approach J. lorentzii but differ in the persistent bracteoles, short petioles and relatively dense inflorescences.

26. Jacquemontia velutina Choisy (1845: 398). Type: Brazil, Pohl s.n. (lectotype BR-0000005843619, designated here, isolectotypes BR-000005843947, M-0184751).

Slender twining herb, all vegetative parts densely tomentose. Leaves ovate to suborbicular, rounded to obtuse, mucronate; petioles usually short $1-2(-3)$ $\mathrm{cm}$. Inflorescence compact; bracteoles linear, $1-2 \mathrm{~mm}$, inconspicuous; pedicels $1-3 \mathrm{~mm}$; sepals subequal, ovate to elliptic, obtuse to rounded, usually less than $4 \mathrm{~mm}$ long, outer tomentose, inner with broad scarious margins; corolla relatively narrow, dull pink, white or blue, 13 - 17 mm. Fig. 18C, D.

TYPIFICATION. The type specimen at Brussels exactly corresponds to Choisy's citation of "herb. Martius n. 37" and is annotated by Choisy. Specimens at M and W are, therefore isotypes.

DISTRIBUTION \& HABITAT. Disturbed cerrado vegetation, often on sandy soil, occurring in scattered locations in eastern Bolivia, eastern Paraguay and the Cerrado biome region of Brazil. It is absent from the Chaco and most of the caatinga region of NE Brazil. Map 6.

SELECTED SPECIMENS EXAMINED. BOLIVIA (12 seen). Santa Cruz: Ichilo: Buenavista, J. Steinbach 7040 (A, BM, MO); La Arboleda, J. R. I. Wood 10982 (K, LPB); Nuflo de Chávez: Concepción, J. R. I. Wood et al. 25046 (K, LPB, UB, USZ), south of Concepción, O. Morrone E M. J. Belgrano 4972 (LPB, SI), Lomerío, M. T. Martinez-Ugarteche 58 (K, USZ); Velasco: W of Santa Rosa de la Roca, J. R. I. Wood et al. 27786 (L, LPB, USZ), Santa Ana de Velasco, G. Seijo E V. B. Solis Neffa 3286 (CTES, LPB), San Ignacio-San Miguel, J. R. I. Wood et al. 28666 (K, LPB, USZ).

CONSERVATION STATUS. Jacquemontia velutina should be treated as Near Threatened (NT) based on its extent of occurrence of $20,454.895 \mathrm{~km}^{2}$. The category of
Endangered (EN) based on its area of occupancy does not seem appropriate given its presence in disturbed cerrado vegetation including roadsides. It is quite possibly under-recorded because it flowers relatively late in the season.

PHENOLOGY. Found in flower from March to July. NOTE. This species was treated as a misidentification of Jacquemontia lorentzii in the Catálogo de las Plantas Vasculares del Cono Sur (Austin \& Costea 2008) but is in fact common in eastern Paraguay, from where we have seen the following collections:

PARAguay. Dept. Alto Parana: Itaipú Binacional 237 (MO, PY). Dept. Amambay: A. Schinini et al. 36023 (PY) and N. Soria 6161 (FCQ). Dept. Caazapa: R. Degen 1553 (FCQ, MO). Dept. Caaguazú: Zardini E Bertoni 28203 (PY). Dept. Canindeyú: G. Marín Ẽ B. Jiménez 272 (BM, MO, PY). Dept. Concepción: Est. Primavera, A. L. Woolston 1590 (K). Dept. Cordillera: Balansa 4389 (K, P). Dept. Guairá: E. Hassler 8845 (K). Dept. Itapúa: A. Pin et al. 616 (PY). Dept. Paraguarí: J. R. I. Wood et al. 28150 (FCQ). Dept. San Pedro: Simonis et al. 63 (MO, PY, U).

Unlike Jacquemontia cumanensis, another species of eastern Bolivia, this is a Cerrado, rather than a Chaco species as is clear from its distribution in Bolivia and Paraguay.

27. Jacquemontia villosissima Ooststr. (Ooststroom 1936: 218). Type: Brazil, Minas Gerais, Curvellos et in campis Sta Luzia, Oct. 1834, Riedel 2754 (holotype LE, n.v.).

Decumbent perennial herb, with long stems, all parts densely villous with long spreading apparently simple hairs. Leaves subsessile, oblong elliptic, narrowed at both ends, acute, numerous, the internodes short; inflorescence of few terminal and axillary racemes, 2 $5 \mathrm{~cm}$ in length, the flowers imbricate; bracteoles linear-lanceolate, acute, villous; sepals subequal, linear, acute, erect, $6-7 \times 0.5 \mathrm{~mm}$, villous; corolla pale blue, c. $1 \mathrm{~cm}$ long.

DISTRIBUTION \& HABITAT. A globally rare species of campo sujo known from a few locations in central Brazil (Minas Gerais and Goías states) and a single location in eastern Bolivia. Map 14.

SPECIMENS eXAMINED. BoliviA. Santa Gruz: Velasco, P.N. Noel Kempff Mercado, the meseta, near Camp. Huanchaca 2, J. R. I. Wood et al. 18229 (K, LPB, USZ). CONSERVATION STATUS. This species is globally rare and should be treated as Critically Endangered (CR) in Bolivia as it is known from a single collection. Even though the collection locality is in a protected area, the absence of other collections suggests it is very rare and the only population could be lost by any habitat change, such as the development of scrub.

NOTES. Field notes accompanying the Bolivian collection describe this plant as a decumbent perennial. 
28. Jacquemontia weberbaueri Helwig (1927: 1136). Type: Peru, Abajo de Santa Cruz, Prov. Hualgayoc, $1700 \mathrm{~m}$, A. Weberbauer 4154 (holotype $\mathrm{B} \dagger$ (photo FFOBN013774), isotypes G-11222052, USM-000312).

Twining perennial with pubescent to tomentose, oblongovate leaves often with fulvous indumentum, the apex obtuse with a very distinctive $2 \mathrm{~mm}$ long mucro. Inflorescence of moderately lax subcorymbose cymes with 10 - 15 flowers; pedicels $2-9 \mathrm{~mm}$, bracteoles filiform, to $1.5 \mathrm{~mm}$; sepals $5-6 \times 2-2.5 \mathrm{~mm}$ long, subequal, oblong to narrowly oblong-elliptic, acuminate, pubescent; corolla $18-22 \mathrm{~mm}$, lilac. The apical mucro on the leaves is very distinct. Fig. 20.

DISTRIBUTION \& HABITAT. Dry secondary woodland usually found between 450 and $1100 \mathrm{~m}$ in northern Andean Peru, essentially in the Marañón valley region. Records from Ecuador (Austin 1982a) are probably errors for Jacquemontia peruviana. It is almost certainly endemic to Peru. Map 3.

SEleCted SPECIMENS EXAMINed. PERU (10 seen). Amazonas: Bagua, $5 \mathrm{~km}$ E of Bagua on road to La Peca, Marañon Valley, A. Gentry et al. 22782 (MO); 20 $25 \mathrm{~km}$ S of Tarapoto, A. Gentry et al. 37847 (MO, OXF). Cajamarca: San Ignacio, Namballe, margen derecha del Río Namballe, J. Campos et al. 4070 (MO, OXF); San José de Lourdes, El Crucero, C. Diaz et al. 10693 (MO), Las Juntas, R. Rojas et al. 0889 (MO); Jaén, Shumba, S. Llatas Quiroz 2201 (F).

CONSERVATION STATUS. Based on its extent of occurrence of $25,202.329 \mathrm{~km}^{2}$, this species should be considered Near Threatened (NT) but, based on an area of occupancy of $40,000 \mathrm{~km}^{2}$, it might be regarded as Endangered (EN). Further studies of the known populations are needed to confirm which categorisation is correct but NT seems more likely given that the Maranón valley is threatened by habitat fragmentation and the construction of dams to produce hydroelectricity (Marcelo-Peña et al. 2016).

NOTE. It is perhaps most similar to Jacquemontia boliviana but differs in its laxer inflorescence, sparser indumentum and different leaves as detailed under that species. J. corymbulosa is also somewhat similar but with shorter sepals c. $4 \mathrm{~mm}$ long and a dense subcapitate inflorescence.

\section{Unassigned specimens}

It is not possible to identify all specimens reliably for a variety of reasons, most commonly because the material is inadequate. However, a small number of specimens clearly represent unusual forms or possibly distinct species. Several cases have been noted following the descriptions of species they most resemble but the following are somewhat isolated morphologically:
A. Gentry, R. Foster Eं M. Pena 75194 (MO, LPB, USZ) from Curuyuqui on the Río Parapeti in Cordillera Province, Santa Cruz, Bolivia at $18^{\circ} 45^{\prime} 56^{\prime \prime S} 62^{\circ} 13^{\prime} 59^{\prime \prime W}$ at $350 \mathrm{~m}$ appears to be a distinct species but may not be a Jacquemontia. The specimen has woody stems, densely pilose sepals, and solitary flowers but lacks corollas. It was identified as Jacquemontia rufa Dammer at MO but is not that species.

L. Valenzuela et al. 5270 (MO, OXF) and L. Valenzuela et al. 9222 (MO, OXF) somewhat resemble Jacquemontia velutina but the location and altitude would appear to rule out that species. Both come from Cusco in Peru, the former from Yanatile District in Calca Province at $12^{\circ} 19^{\prime} \mathrm{S} 72^{\circ} 18^{\prime} \mathrm{W}$ at $1815 \mathrm{~m}$, the latter from Echarate District in La Convencion Province at $12^{\circ} 47^{\prime} 43^{\prime \prime} \mathrm{S} 73^{\circ} 15^{\prime} 24^{\prime \prime} \mathrm{W}$ at $1100 \mathrm{~m}$. Both plants have rather large tomentose leaves and a compact inflorescence with sepals pubescent, especially towards the base. The blue corolla is rather small. P. Nuñez $\mathcal{E}^{\circ}$ G. Ortíz 12941 (MO) and W. Galiano et al. 4385 (MO, $\mathrm{OXF}$ ) from the same general area might also represent the same taxon but the corolla of the former is reported to be white and the latter has glabrous sepals. None of these four specimens is particularly informative morphologically and further collections from the area are needed to resolve the identity of these plants.

\section{Acknowledgements}

We are very grateful to various herbaria for access to their collections and/or loan of specimens, in Bolivia (BOLV, HSB, LPB and USZ), the UK (BM, K and $\mathrm{OXF}$ ) and in the United States (F, MO), where Christine Niezgoda and Jim Solomon have been especially helpful. Rosa Degen and Guillermo Seijo allowed access to the collections in FCQ and CTES respectively, and Maira Tatiana Martinez kindly sent us images of many specimens of Jacquemontia from Bolivia and Paraguay which she found during her visit to Corrientes (CTES). Hibert Huaylla sent photographs of some specimens stored in USM in Lima. We have also added records of Ecuador specimens John Wood has seen at AAU, LOJA, QCA and QCNE. We owe special thanks to Alfredo Fuentes and Julia Gutiérrez for showing us specimens and photographs of new species but we have also been sent useful photos by Alexander Parada, Louise Emmons and Oliver Whalley, which are included in this paper. Over the years John Wood has benefitted from the company and support of various botanists who in different ways have contributed to this paper including Gina Aramayo, Stephan Beck, Mark Carine, Hibert Huaylla, Roxana Ledezma, Maira Tatiana Martinez, Edgar Mayta, John and Lynsey Pink, Daniel Soto, Daniel Villarroel and Beth Williams. At Oxford John Wood is 
very grateful to Denis Filer and John Baker for help with databases, maps and plates, to James Ritchie for help with the scans, to Serena Marner for processing loans and to Rosemary Wise for preparation of the line drawings that illustrate species described and discussed in this paper.

Open Access This article is licensed under a Creative Commons Attribution 4.0 International License, which permits use, sharing, adaptation, distribution and reproduction in any medium or format, as long as you give appropriate credit to the original author(s) and the source, provide a link to the Creative Commons licence, and indicate if changes were made. The images or other third party material in this article are included in the article's Creative Commons licence, unless indicated otherwise in a credit line to the material. If material is not included in the article's Creative Commons licence and your intended use is not permitted by statutory regulation or exceeds the permitted use, you will need to obtain permission directly from the copyright holder. To view a copy of this licence, visit http://creativecommons.org/ licenses/by/4.0/.

\section{References}

Acevedo-Rodríguez, P. \& Strong, M. T. (2012). Catalogue of Seed Plants of the West Indies. Smithsonian Contr. Bot. 98: 1 - 1192. https://doi.org/10.5479/ si.0081024X.98.1.

Austin, D. F. (1982a). Fam. 165. Convolvulaceae. In: G. Harling \& B. Sparre (eds), Flora of Ecuador 15: 1 95. Department of Systematic Botany, University of Götenberg and the Section for Botany, Riksmuseum, Stockholm.

(1982b). Convolvulaceae. In: Z. Luces de Febres \& J. A. Steyermark (eds), Flora of Venezuela 8: 15 - 226. Fundación Instituto Botánico de Venezuela, Caracas. (1998) [dated 1999]. The genus Aniseia (Convolvulaceae). Syst. Bot. 23 (4): $411-420$.

\& Costea, M. (2008). Convolvulaceae. In: D. O. Zuloaga, O. Morrone \& M. J. Belgano (eds), Catálogo de las plantas vasculares del Cono Sur. Monogr. Syst. Bot. Missouri Bot. Gard. 107 (2): 1936 1966. Missouri Botanical Garden Press, St Louis.

Baker, J. G. (1894). Diagnoses Africanae II. Convolvulaceae. Bull. Misc. Inform., Kew 1894 (86): 67 - 74.

Bentham, G. (1839 - 57). Plantas Hartwegianas imprimis Mexicananas. W. Pamplin, London. https:// doi.org/10.5962/bhl.title.437

(1845 [dated 1844]). The Botany of the Voyage of H.M.S. Sulphur. Smith, Elder \& Co, London. https://doi.org/10.5962/bhl.title.908
Buril, M. T. (2013). Sistemática e Filogenia de Jacquemontia (Choisy), Convolvulaceae. Tese de Doutorado, Universidade Federal de Pernambuco, Recife. https://attena.ufpe.br/bitstream/123456789/ 12909/1/TESE\%20MariaTereza\%20Buril.pdf

\& Alves, M. (2011). A new species of Jacquemontia (Convolvulaceae) from northeastern Brazil. Brittonia 63: 436 - 441.

Maciel, J. R. \& Alves, M. (2015). Distribution Patterns and Areas of endemism of Brazilian Jacquemontia (Convolvulaceae) species. Edinburgh J. Bot. 72: 13 - 33 .

\& Staples, G. (2018) Lectotypification of species names in Jacquemontia. Nord. J. Bot. e01309 https:/ / doi.org/10.1111/njb.01309

Carine, M. A., Russel, S. J., Santos-Guerra, A. \& Francisco-Ortega, J. (2004) Relationships of the Macaronesian and Mediterranean floras: molecular evidence for multiple colonizations into Macaronesia and back-colonizations of the continent in Convolvulus (Convolvulaceae). Amer. J. Bot. 91 (7): $1070-1085$.

Cavanilles, A. J. (1799). Icones et descriptiones plantarum, Vol. 5. Typografia Regia, Madrid. http:// bibdigital.rjb.csic.es/spa/Libro.php?Libro=241

Choisy, J. D. (1834). Convolvulaceae Orientales. Mém. Soc. Phys. Genève 6: 383 - 502 (reprinted with pagination 1 120). http://www.biodiversitylibrary.org/bibliography/ 13710

(1838 [dated 1837]). De Convolvulaceis dissertation secunda. Mém. Soc. Phys. Genève 8 (1): 121 164. (reprinted with pagination 43 - 86). http:// www.biodiversitylibrary.org/bibliography/13710

(1845). Convolvulaceae. In: A. P. de Candolle (ed.), Prodromus Systematis Naturalis 9: 323 - 462. Fortin, Masson \& Co, Paris. https:// www.biodiversitylibrary.org/item/7158\#page/5/ mode/lup

Dammer, U. (1897). Convolvulaceae. In: I. Urban, Plantae novae americanae imprimis Glaziovianae 1. Bot. Jahrb. Syst. 23, Beibl. 57: 36 - 42. http:// www.biodiversitylibrary.org/bibliography/60

D'Arcy, W. G. (1970). Jacquin names, some notes on their typification. Taxon 19: $554-560$.

Desrousseaux, L. A. J. (1792) [dated 1789]. Convolvulaceae. In: J. Lamarck, Encyclopédie méthodique 3 (1): 539 - 568. Paris. http:// w w w. pla n t i l l u s t r a t i o n s.org/ volume.php?id_volume $=4623$

Dillenius, J. J. (1732). Hortus Elthamensis 2: 2: 428, t. 318, f. 410. Sumptibus auctoris, Londini.

Don, G. (1838). A general history of the dichlamydeous plants, Vol. 4. J .G. \& F. Rivington et al., London. https://doi.org/10.5962/bhl.title.502 
Flora do Brasil 2020 under construction. Jardim Botânico do Rio de Janeiro. Available at: <http:// reflora.jbrj.gov.br/reflora/floradobrasil/. Accessed 12 Nov. 2018.

Grisebach, A. H. R. (1862 [dated 1864]). Flora of the British West Indian Islands. Lovell Reeve \& Co, London. https://doi.org/10.5962/bhl.title.143

Hallier, H. (1893). Versuch einer natürlichen Gliederung der Convolvolvulaceen auf morphologischer und anatomischer Grundlage. Bot. Jahrb. Syst. 16: 453 - 591. http:// www.biodiversitylibrary.org/bibliography/ 60

(1899a). Zur Convolvulaceenflora Amerika's. Jahrb. Hamburg. Wiss. Anst. 16, Beih. 3: 19 - 56. http:// www.biodiversitylibrary.org/bibliography/9594

(1899b). Convolvulaceae. In: R. Chodat \& E. Hassler, Plantae Hasslerianae. Bull. Herb. Boissier 7, App. 1: 43 - 54. https://www.biodiversitylibrary.org/ item/104952

Hassler, E. (1911). Ex herbario Hassleriano: Novitates Paraguarienses. XIII. Repert. Spec. Nov. Regni Veg. 9: $193-197$.

Helwig, B. (1927). Convolvulaceae austro-americanae novae. Notizbl. Bot. Gart. Mus. Berlin-Dahlem 9: 1136 - 1138.

Hoehne, F. C. (1922). Convolvuláceas dos Hervários: Horto "Oswaldo Cruz", Museu Paulista e Commissão Rondon. Anexos Mem. Inst. Butantan, Secc. Bot. 1 (6): 1 - 83. https:// www.biodiversitylibrary.org/page/4523654

Jacquin, N. J. (1791 [dated 1790]). Collectanea ad botanicum, chemiam et historiam naturalem spectantia, Vol. 4. Officina Wappleriana, Wien.

Krapovickas, A. (2009). Novedades en Convolvuláceas argentinas. Bonplandia (Corrientes) 18 (1): 57 - 64. https://www.jstor.org/stable/41941342

Kunth, C. S. (1819 [dated 1818]). Nova Genera et Species Plantarum, Vol. 3. Librairie Grecque-Latine-Allemande, Paris. https://doi.org/10.5962/ bhl.title. 640

Kuntze, O. (1891). Revisio Generum plantarum, Vols. 1 - 2. A. Felix, Leipzig. https://doi.org/10.5962/bhl.title.327 (1898). Revisio Generum plantarum, Vol. 3. A. Felix, Leipzig. https://doi.org/10.5962/bhl.title.327

Linnaeus, C. (1753). Species plantarum (ed. 1). Salvius, Stockholm. https://doi.org/10.5962/bhl.title.669

Mabberley, D. J. (2017). Mabberley's Plant Book. Cambridge University Press, Cambridge.

Macbride, J. F. (1959). Jacquemontia. In: Flora of Peru. Publ. Field Mus. Nat. Hist., Bot. Ser. 13, part 5 (1): 512 $-521$.

McDonald, J. A. (1993). Convolvulaceae 1. Flora of Veracruz, fasc. 73: 1 - 95. Instituto de Ecologia, A.C., Xalapa, Veracruz \& University of California, Riverside.

Marcelo-Peña, J. L., Huamantupa, I., Särkinen, T. \& Tomazello, M. (2016). Identifying Conservation
Priority Areas on the Marañón Valley (Peru) based on Floristic Inventories. Edinburgh J. Bot. 73 (1): 95 - 123. https://doi.org/10.1017/ S0960428615000281

Meisner, C. F. (1869). Convolvulaceae. In: C. F. P. von Martius (ed.), Flora Brasiliensis 7: 199 - 362. F. Fleischer, Leipzig. http://www.biodiversitylibrary.org/item/9668

Meyer, G. (1818). Primitiae Florae Essequeboensis. Henrici Di e te ri c h, Göt tingen. h t t p s : / / www.biodiversitylibrary.org/page/33442697\#page/

Moore, S. (1895). The Phanerogamic Botany of the Matto Grosso Expedition, 1891 - 92. Trans. Linn. Soc., London, Bot. Ser. 2, 4: 265 - 516. http:// onlinelibrary.wiley.com/doi/10.1111/tlb.189

Moreira, A. L. C., Simão-Bianchini, R. \& Cavalcanti, T. B. (2018). Sinopse do gênero Jacquemontia Choisy (Convolvulaceae) nos Estadosde Goiás e Tocantins, Brasil. Hoehnea 45 (2): 192 - 201. https://doi.org/ 10.1590/2236-8906-16/2017.

Moricand, M. E. (1834 - 47). Plantes Nouvelles d'Amérique. J-G Fick, Geneva.

Muñoz-Rodríguez, P., Carruthers, T., Wood, J. R. I., Williams, B. R. M., Weitemier, K., Kronmiller, B., Goodwin, Z., Sumadijaya, A., Anglin, N. L., Filer, D., Harris, D., Rausher, M. D., Kelly, S., Liston, A. \& Scotland, R. W. (2019). A taxonomic monograph of Ipomoea integrated across phylogenetic scales. $\mathrm{Na}$ ture Plants 5: 1136 - 1144; supplementary information 1 - 49. (2019). https://doi.org/10.1038/ s41477-019-0535-4

Namoff, S., Thornton, H. E. B., Lewis, C. E. Oviedo, R. \& Francisco-Ortega, J. (2007). Molecular evidence for phylogenetic relationship of Jacquemontia reclinata House (Convolvulaceae) $=$ a critically endangered species from south Florida. Bot. J. Linn. Soc. 154: 443 - 454.

Nees ab Esenbeck, C. G. E. \& Martius, C. F. P. von (1823). Beitrag zur Flora Brasiliens. Nova Acta Phys.Med. Acad. Caes. Leop.-Carol. Nat. Cur. 11: 1 - 190. https://www.biodiversitylibrary.org/item/113890

O'Donell, C. A. (1950). Convolvulaceas Americanas Nuevas o Criticas 2. Lilloa 23: 457 - 509

(1960a). Convolvuláceas argentinas II. Lilloa 30: 5 - 29. (1960b). Las especies de Jacquemontia de Peru. Lilloa 30: 71 - 89 .

Ooststroom, S. J. van (1936). Beiträge zur Kenntnis der südamerikanischen Convolvulaceen. Meded. Bot. Mus. Herb. van de Rijks. Univ. Utrecht 28: Extrait du Recueil Trav. Bot. Neerl. 33: 211 - 222.

Pastore, M., Moreira, A. L. C., Cavalcanti, T. B. \& SimãoBianchini, R. (2017). A taxonomic study of Jacquemontia evolvuloides (Moric.) Meisn. and related species (Convolvulaceae). Adansonia, sér. 3, 39 (2): 149 - 166.

Robertson, K. R. (1971). A revision of the genus Jacquemontia (Convolvulaceae) in North and Central 
America and the West Indies. PhD thesis, Washington University, St Louis. \& Austin, D. F. (2012). Jacquemontia. In: G. Davidse, S. M. Sousa, S. Knapp \& F. Chiang (eds), Flora Mesoamericana 4 (2): 343 - 346. Universidad Nacional Autónoma de México, Missouri Botanical Garden, \& The Natural History Museum, London.

Roberty, G. E. (1952). Genera Convolvulacearum. Candollea 14: 11 - 60.

Roemer, J. J. \& Schultes, J. A. (1819). Caroli a Linné Systema vegetabilium secundum [ed. 15 bis] Vol. 4: 1 888. J. G. Cotta, Stuttgart. https://doi.org/ 10.5962/bhl.title.825

Ruiz, H. \& Pavon, J. A. (1799). Flora Peruviana et Chilensis Vol. 2: 1 - 76. Gabrielis de Sancha, Madrid. https://doi.org/10.5962/bhl.title.814

Rusby, H. H. (1896). An enumeration of the plants collected in Bolivia by Miguel Bang - $111 \mathrm{Mem}$. Torrey Bot. Club 6 (1): 1 - 130. https:// www.biodiversitylibrary.org/page/31869314\#page/

(1899). An enumeration of the plants collected by Dr H. H. Rusby in South America 1885 - 1886 XXVI. Bull. Torrey Bot. Club 26: 145 - 152. https:// www.biodiversitylibrary.org/page/710032\#page/

(1927). Descriptions of new genera and species of plants collected on the Mulford Biological Exploration of the Amazon Valley 1921 - 22. Mem. New York Bot. Gard. 7: 205 - 388. https:// www.biodiversitylibrary.org/page/44065571\#page/

Sandwith, N. Y. (1930). In: Decades Kewenses Decas CXXIV. Bull. Misc. Inform., Kew 1930 (4): 153 - 160.

Seeman, B. (1852 - 57). The botany of the voyage of H.M.S. Herald. London, Lovell Reeve. https:// www.biodiversitylibrary.org/page/519109

Standley, P. C. (1936). Studies of American Plants - VI. Publ. Field Mus. Nat. Hist., Bot. Ser. 11(5): 145 - 276. https:/ / www.biodiversitylibrary.org/page/ 2396983\#page/

Staples, G. W., Buril, M. T., Simões, A. R. \& Govaerts, R. (2015). Nomenclatural corrections in Convolvulaceae diversae. Phytologia 97 (3): 219 - 223. http:// www.phytologia.org/uploads/2/3/4/2/23422706/ 97(3)219223staples_et_al_convolvulaceae_nomenclature.pdf

Stefanovic, S., Krueger, L. \& Olmstead, R. G. (2002). Monophyly of the Convolvulaceae and circumscription of their major lineages based on DNA sequences of multiple chloroplast loci. Amer. J. Bot. 89: $1510-1522$.

Austin, D. F. \& Olmstead, R. G. (2003). Classification of Convolvulaceae: A Phylogenetic Approach. Syst. Bot. 28 (4): 791 - 806.

Steudel, E. G. (1841). Nomenclator Botanicus. Editio secunda 2 (1): 407.

Vahl, M. (1797). Eclogae americanae, Vol. 1. Nicolaus Möller et filius. Hauniae [Copenhagen].

Verdcourt, B. (1963). Convolvulaceae. In: C. E. Hubbard \& E. Milne-Redhead (eds), Flora of Tropical East Africa. HMSO, London.

Wood, J. R. I. (2011). Clinopodium L. in Bolivia. Kew Bull. 66: 1 - 28.

, Simão-Bianchini, R. \& Fuentes, A. F (2015a). In:

P. M. Jorgensen, M. Nee \& S. G. Beck (eds), Catálogo de las Plantas Vasculares de Bolivia 1: 520 531. Missouri Botanical Garden Press, St Louis. , Carine, M. A., Harris, D., Wilkin, P., Williams, B. \& Scotland R. W. (2015b). Ipomoea (Convolvulaceae) in Bolivia. Kew Bull. 70 (31): 1 124. https://doi.org/10.1007/512225-015-9592-7

\& Scotland, R. W. (2017a). Notes on Ipomoea (Convolvulaceae) from the Amazonian periphery. Kew Bull. 72 (10): 1 - 18. https://doi.org/10.1007/ S12225-017-9682-9

\& Scotland, R. W. (2017b). Notes on Ipomoea L. (Convolvulaceae) in Cuba and neighbouring islands with a checklist of species found in Cuba. Kew Bull. 72 (45): 1 - 16. https://doi.org/10.1007/ S12225-017-9717-2

\section{Publisher's Note}

Springer Nature remains neutral with regard to jurisdictional claims in published maps and institutional affiliations. 